Mulyani Mudis Taruna

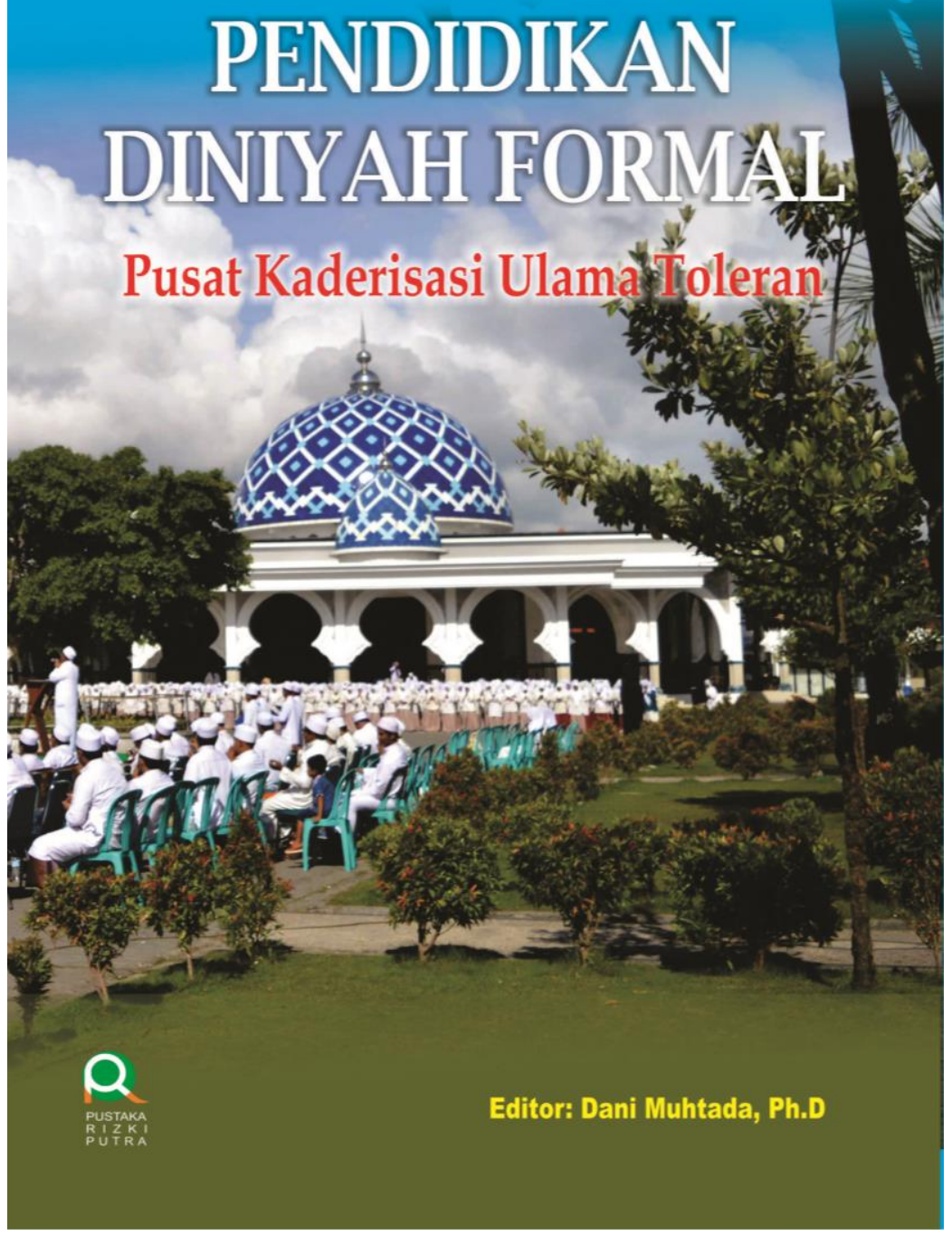




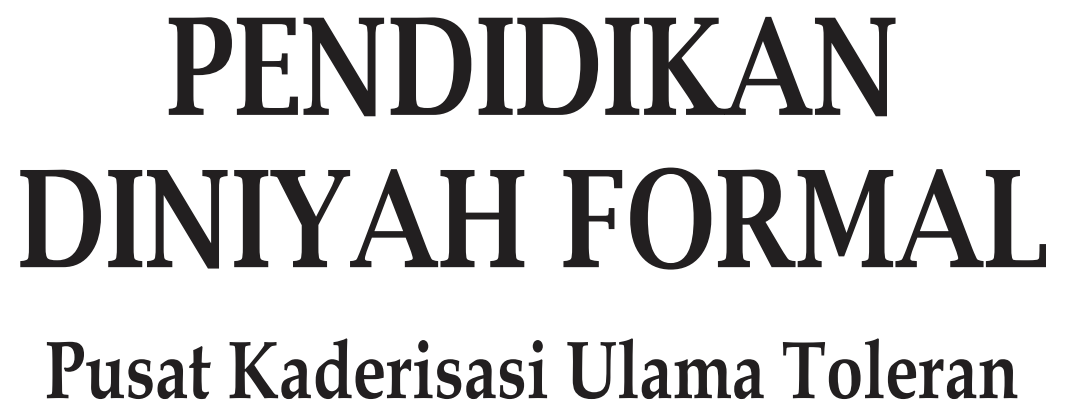




\section{UNDANG-UNDANG HAK CIPTA NO. 19 TAHUN 2002}

\section{Pasal 2}

(1). Hak Cipta merupakan hak eksklusif bagi Pencipta dan Pemegang Hak Cipta untuk mengumumkan atau memperbanyak ciptaannya, yang timbul secara otomatis setelah suatu ciptaan dilahirkan tanpa mengurangi pembatasan menurut peraturan perundang-undangan yang berlaku.

\section{Pasal 72}

(1). Barangsiapa dengan sengaja dan tanpa hak melakukan perbuatan sebagaimana dimaksud dalam Pasal 2 ayat (1) dipidana dengan pidana penjara paling singkat 1 (satu) bulan dan/atau denda paling sedikit Rp. 1.000.000,- (satu juta rupiah), atau pidana penjara paling lama 7 (tujuh) tahun dan denda paling banyak Rp. 5.000.000.000,- (lima miliar rupiah).

(2). Barangsiapa dengan sengaja menyiarkan, memamerkan, mengedarkan, atau menjual kepada umum suatu ciptaan atau barang hasil pelanggaran Hak Cipta atau Hak Terkait sebagaimana dimaksud pada Pasal 2 ayat (1), dipidana dengan pidana penjara paling lama 5 (lima) tahun dan/atau denda paling banyak Rp. 500.000.000,- (lima ratus juta rupiah). 

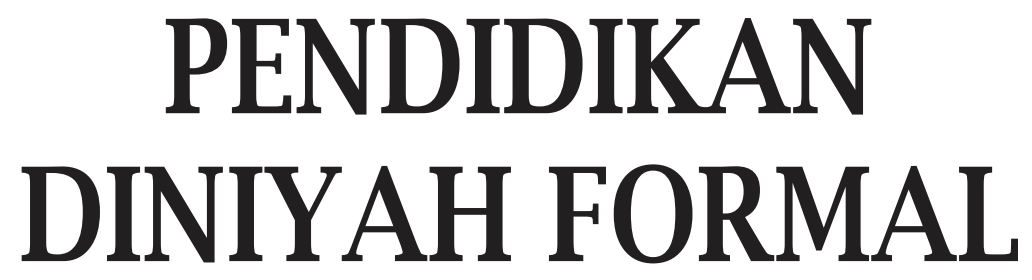

\section{Pusat Kaderisasi Ulama Toleran}

Editor:

Dani Muhtada, Ph.D.

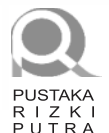




\title{
PENDIDIKAN DINIYAH FORMAI Pusat Kaderisasi Ulama Toleran
}

\author{
Penulis: \\ Mulyani Mudis Taruna \\ Editor: \\ Dani Muhtada, Ph.D. \\ Layout Isi: \\ Yuli Pratiwi \\ Desain Cover: \\ Abu Fadhel \\ Diterbitkan oleh: \\ PUSTAKA RIZKI PUTRA \\ Jl. Hayam Wuruk No. 42-G Semarang \\ Telp. (024) 8449557 Faks. (024) 8311268 \\ Email: rizkiputra@gmail.com \\ Anggota IKAPI \\ ISBN: 978-602-6244-43-7 \\ Hak Cipta dilindungi Undang-undang No. 19 Th. 2002 \\ All right reserved \\ Cetakan Pertama, Agustus 2018
}




\section{KATA PENGANTAR PENULIS}

Perkembangan Pondok pesantren salafiyah mengalami lompatan dalam penyelenggaraan lembaga pendidikan formal. Pada awalnya pondok pesantren salafiyah hanya memfokuskan pada penguasaan kitab kuning (kutub atturats) dengan orientasi pada tafaqquh fi ad-diin, akan tetapi dalam perkembangannya membuka pembelajaran klasikal dengan tingkatan kitab dan pembelajaran dengan model bandongan. Bahkan selanjutnya menyelenggarakan pembelajaran dengan model klasikal berdasarkan pada tingkatan kelas atau dengan istilah sistem madrasi.

Seiring dengan perkembangan zaman dan tuntutan masyarakat secara umum, pondok pesantren mulai membuka dan menyelenggarakan lembaga pendidikan formal yang dapat melanjutkan studi ke jenjang yang lebih tinggi diluar pondok pesantren. Penyelenggaraan sekolah formal ini memiliki konsekuensi harus mengakomodir kurikulum dari Pemerintah dan transaksi ini biasanya dengan model 30\% kurikulum umum dan 70\% kurikulum keagamaan Islam. Dari aspek ini, pondok pesantren sudah mengalami pergeseran orientasi dari tafaqquh fi ad-ddin yang mengkhususkan pada perkaderan ulama dan lembaga yang 
menciptakan "majikan" minimal untuk dirinya sendiri menjadi lembaga yang berorientasi pada profan.

Jargon Almukhaafdlotu 'alaa al-qodiimissholih wal akhdzu bil jadidil ashlah yang menjadi jargon pondok pesantren salafiyah merupakan sifat adaptifitas pondok pesantren salafiyah terhadap perkembangan zaman. Namun demikian, ketika mengambil nilai-nilai baru yang lebih baik tidak sedikit pondok pesantren "terjebak" dalam rutinitas kelembagaan pendidikan formal yang yang tidak lagi mencetak kader ulama tafaqquh fi addiin. Persoalan ini menjadikan Kementerian Agama yang selalu bersinggungan dengan pondok pesantren salafiyah dan ulama menyusun regulasi agar dapat mengakomodir seluruh kepentingan pondok pesantren salafiyah.

PMA Nomor 13 Tahun 2014 adalah jawaban dari keinginan pondok pesantren salafiyah menyelenggarakan pendidikan formal akan tetapi tetap pada koridor utamanya sebagai pencetak kader ulama. Dengan demikian, diharapkan santri pondok pesantren salafiyah adalah sekaligus peserta didik pada lembaga pendidikan formal. Hal ini dikarenakan berada pada dua "sisi mata uang" yang tidak dapat dipisahkan, yaitu tetap sebagai kader ulama dan pada sisi yang lain memiliki ijazah formal yang dapat digunakan untuk melanjutkan studi ke Perguruan Tinggi yang diinginkan. 
Membaca buku ini paling tidak memunculkan empat pertanyaan mendasar, yaitu pertama, mungkinkah pendidikan diniyah menjadi lembaga pendidikan formal sebagaimana sekolah formal pada umumnya? Hal ini karena pendidikan diniyah dalam sejarahnya adalah lembaga pendidikan non formal. Kedua, Kalau ada ulama toleran maka secara implisit terdapat ulama yang intoleran, bagaiman dengan ulama yang didik pada Pendidikan Diniyah Formal (PDF) Ulya Al Fithrah? dan yang ketiga benarkah pendidikan diniyah yang diformalkan dapat dijadikan pusat kaderisasi ulama? lalu bagaimana dengan pondok pesantren salafiyah yang selama ini memproduk ulama-ulama penerus ulama salafussholih sebagai pertanyaan yang keempat. Dari keempat pertanyaan tersebut dijawab dalam buku ini melalui kajian riset yang mendalam.

Surabaya, 2018 



\section{KATA PENGANTAR EDITOR}

Oleh: Dani Muhtada, Ph.D.

Sejarah pendidikan Islam di Indonesia mengenal dua lembaga pendidikan tua yang perannya dalam pengembangan pendidikan tidak bisa diabaikan, yaitu pesantren dan madrasah diniyah. Keduanya sama-sama mengajarkan pendidikan agama. Bedanya, jika pesantren menggunakan system pendidikan berasrama, maka madrasah menggunakan system klasikal dalam pengajaran agama. Meskipun ada yang menganggap usia dua lembaga ini sama (Alwasilah, 2009), namun kebanyakan ahli berpendapat bahwa madrasah hadir jauh setelah pesantren eksis. Madrasah diduga baru lahir setelah abad ke-20 (Steenbrink, 1974; Kelabora, 1976; Zuhairini et al., 1992; Azra \& Afianty, 2005; Yunanto \& Harun, 2005). Para ahli berpendapat bahwa kelahiran madrasah di Indonesia dipengaruhi oleh kebangkitan Islam di Timur Tengah dan system pendidikan colonial Belanda (Zuhairini et. al, 1992; El-Saha, 2008).

Dalam perkembangannya, kedua model pendidikan agama ini mengalami tantangan yang tidak ringan. Di awal 
kemerdekaan, system pendidikan nasional memperkuat dualisme pendidikan, yaitu umum (sekuler) dan agama, yang benihnya sudah muncul sejak zaman kolonial. Lembaga pendidikan umum berada di bawah Kementerian Pendidikan, sedangkan lembaga pendidikan agama menjadi domain Kementerian Agama. Dualisme system pendidikan ini pada gilirannya melahirkan efek samping yang kurang menguntungkan bagi madrasah, yaitu marginalisasi madrasah dalam konstelasi pendidikan nasional.

Untuk menyelematkan madrasah dari posisi marginal tersebut, pemerintah melakukan upaya-upaya untuk "menyetarakan" eksistensi madrasah. Salah satunya dengan mengadopsi kurikulum pendidikan nasional untuk diterapkan di madrasah. Melalui SKB Tiga Menteri Tahun 1975, yang ditandatangani oleh Menteri Agama, Menteri Pendidikan dan Kebudayaan, dan Menteri Dalam Negeri, pemerintah memperkuat posisi madrasah dengan menyetarakan lulusan madrasah dengan lulusan sekolah umum. Dengan kata lain, alumni sekolah madrasah dapat langsung meneruskan pendidikan lanjut di sekolah umum. Sebagai konsekuensi dari penyetaraan ini, madrasah harus merevisi kurikulumnya dengan komposisi 70\% matap elajaran umum dan 30\% mata pelajaran agama (Ramayulis, 2012; Azra \& Afianty, 2005; Zuhairini et al., 1992). Walhasil, karakter "pendidikan agama" di madrasah mulai berkurang secara signifikan 
lantaran materi pendidikan umum (sekuler) menjadi komponen mayoritas dalam kurikulum. Marjinalisasi komponen agama dalam kurikulum madrasah itu semakin kuat ketika pemerintah menerapkan Kurikulum Madrasah 1994, dimana proporsi mata pelajaran umum naik menjadi 82-86\%, sementara proporsi pelajaran agama turun menjadi 16-18\% (Azra \& Afrianty, 2005).

Turunnya komponen agama dalam kurikulum madrasah ini membuat beberapa pengelola bersikukuh mempertahankan identitas Islam dengan mempertahankan model madrasah diniyah. Di madrasah diniyah ini, para peserta didik dapat sepenuhnya belajar dan mendalami materimateri keagamaan, tanpa komponen mata pelajaran umum (sekuler). Hanya saja, karena pendekatannya informal, dan biasa dibuka siang atau sore hari selepas sekolah formal, madrasah diniyah mengalami berbagai kendala untuk mempertahankan eksistensinya. Baik kendala-kendala finansial, maupun kendala yang terkait dengan minat pesertadidik untuk belajar di madrasah. Jumlah siswa madrasah diniyah semakin menurun, seiring dengan semakin susahnya pengelola madrasah diniyah menarik minat para calon guru untuk mengajar di madrasah diniyah.Hal ini tentu mengancam eksistensi madrasah diniyah di tengah masyarakat.

Lahirnya era reformasi dan otonomi daerah seluasluasnya membawa angin segar bagi eksistensi madrasah 
diniyah. Beberapa pemerintah daerah mengeluarkan peraturan daerah yang mencoba memperkuat eksistensi madrasah diniyah. Mereka mewajibkan para peserta didik di daerah masing-masing untuk juga menjadi peserta didik di madrasah diniyah. Tidak hanya itu, di beberapa daerah, ijazah madrasah diniyah menjadi salah satu prasyarat untuk mendaftar di sekolah-sekolah lanjutan umum. Selain itu penguatan kelembagaan madrasah diniyah dilakukan oleh pemerintah dengan memberikan dukungan financial bagi operasional madrasah, termasuk insentif tambahan bagi guru-guru madrasah (Muhtada, 2014). Upaya "formalisasi" madrasah diniyah ini tak pelak memberikan harapan baru bagi penguatan eksistensi madrasah diniyah bagi pendidikan agama di Indonesia.

Buku "Pendidikan Diniyah Formal: Pusat Kaderisasi UlamaToleran" ini memotret peran pendidikan diniyah dalam mencetak kader-kader ulama toleran di Indonesia. Buku ini memberikan pencerahan tentang beberapa hal. Pertama, tentang upaya penguatan pendidikan agama di tengah masyarakat melalui formalisasi pendidikan diniyah. Kedua, tentang peran pendidikan diniyah dalam mencetak para ahli agama yang mampu mengembangkan paham Islam wasathiyah, Islam moderat. Pengembangan paham Islam wasathiyah ini sangat penting di tengah menguatnya arus ortodoksi dalam tubuh masyarakat Muslim di Indonesia. 
Mampukah pendidikan diniyah mencetak kader-kader ulama toleran di tengah tantangan yang tidak mudah ini. Mungkinkah pendidikan diniyah formal mengatasi beragam tantangan pendidikan Islam dewasa ini, sehingga mampu mewujudkan Islam rahmatan lil'alamien di negeri nusantara? Melalui buku ini, pembaca akan mendapatkan perspektif baru tentang bagaimana madrasah diniyah memainkan perannya di tengah masyarakat Indonesia kontemporer. 



\section{DAFTAR ISI}

KATA PENGANTAR PENULIS__v

KATA PENGANTAR EDITOR_ix

DAFTAR ISI__XV

Bab I PENDAHULUAN__1

$\square$ Pendidikan Diniyah Formal; Kajian yang masih terbatas__9

Bab II PONDOK PESANTREN: LEMBAGA PENDIDIKAN TAFAQQUH FI ADDIEN__15

$\square$ Indigenous Pondok Pesantren Salafiyah

$\square$ Pesantren; Sejarah dan Orientasi

Pendidikan__22

$\square$ Kitab Kuning di tengah tarik menarik Kurikulum Pemerintah_27

$\square$ PDF Ulya Pusat Kaderisasi Ulama Toleran;

Sebuah Kerangka Berfikir__29

ㄱetodologi dan Teknik Analisis Data_31

Bab III PENDIDIKAN DINIYAH FORMAL (PDF) ULYA AL FIHTRAH; PENCETAK KADER ULAMA TOLERAN_35

$\square$ Tantangan Pondok Pesantren Assalafi Al Fithrah Menghadapi Era Lembaga Pendidikan Formal__46 
$\square$ Implementasi PDF Ulya di Pondok Pesantren Al Fithrah; Struktur Pengelolaan PDF Al

Fithrah__54

$\square$ Jumlah santri PDF Al Fithrah__56

$\square$ Kurikulum PDF Al Fithrah__ 58

$\square$ Tujuan dan Ruang lingkup Mata Pelajaran__65

1. Kelompok Mata Pelajaran Keagamaan Islam_66

2. Kelompok Mata Pelajaran Umum__87

Bab IV PENDIDIKAN DINIYAH FORMAL; MENERUSKAN PERJUANGAN ULAMA SALAFUSSHOLIH__99

$\square$ PDF Ulya Al Fithrah; Langkah Strategis Menyelenggarakan Pendidikan Diniyah Formal__105

$\square$ PDF Ulya Al Fithrah; Membentuk Kaderisasi Ulama Toleran__118

$\square$ Pendidikan Diniyah Formal Menyongsong Masa Depan Bangsa__121

\section{BAB V PENUTUP_127}

DAFTAR PUSTAKA_131

LAMPIRAN: PMA Nomor 13 Tahun 2014_135

TENTANG PENULIS__171 


\section{Bab I \\ PENDAHULUAN}

Perjalanan Pondok Pesantren di Indonesia selalu mewarnai kehidupan berbangsa dan bernegara, bahkan pondok pesantren di Indonesia lebih dahulu ada dibandingkan keberadaan bangsa Indonesia. Maklum keberadaan pondok pesantren jauh sebelum Indonesia merdeka. Dilihat dari akar sejarah kemerdekaan bangsa Indonesia, pondok pesantren tidak dapat dilepaskan dari salah satu elemen yang kuat untuk melawan penjajah, baik secara kelembagaan maupun perseorangan. Secara kelembagaan, pesantren melibatkan seluruh komponen yang ada di pondok pesantren untuk melawan penjajah dan secara person, Kiai sebagai pimpinan pondok pesantren menjadi penggerak anak bangsa terutama para santri untuk berjuang memerdekakan bangsa Indonesia. Dari sinilah, pondok pesantren secara kelembagaan maupun secara person seorang Kiai mampu menciptakan bangsa Indonesia menjadi bangsa yang merdeka dan berdaulat. 
Era kemerdekaan sampai pada era reformasi dan pasca reformasi, pondok pesantren masih menjadi daya tarik tersendiri terutama ketika terjadi perhelatan pemilihan Presiden dan Wakil Presiden maupun pemiliah anggota Dewan. Pondok pesantren menjadi barang mahal yang memiliki daya tawar tinggi, sehingga para politikus lintas agamapun menggunakan simbol pesantren dan mengadakan kunjungan ke pondok pesantren demi meraih simpati. Daya tarik pesantren ini disebabkan oleh sifat pondok pesantren sebagai lembaga pendidikan keagamaan yang memiliki watak indigenous ke Indonesiaan yang selalu terbuka dengan siapapun (open minded). Di samping itu, Kiai sebagai pimpinan pondok pesantren juga memiliki sifat tasamuh (mudah bergaul dan ramah) kepada siapapun yang mengajak berkawan.

Dalam konteks sejarah pondok pesantren, watak keasliannya tetap dipertahankan dan dijadikan jargon untuk berkemajuan. Istilah mempertahankan tradisi lama dan tetap bertahan pada ortodoksi Islam yang bersumber pada nilainilai Islam yang dibangun oleh para ulama salaf melalui kitab-kitab kuning cukup kuat. Sementar itu menerima pembaharuan dalam berbagai bidang karena sesuatu atau hal-hal baru adalah konsekuensi logis yang harus disikapi dengan positif. Ketika negara mengalami lompatan-lompatan teknologi dan terjadi shock culture di berbagai wilayah, pondok pesantren tetap "Kekeuh" mempertahankan tradisinya tanpa sedikitpun tergeser dan tergusur. Dalam bahasa 
Moeslim Abdurrahman bahwa peranan pesantren adalah sebagai agen ortodoksi Islam yang paling penting dalam sejarah yang berarti lebih banyak memperhatikan bagaimana menjaga kesinambungan ajaran Islam dari tarikan akulturatif berbagai unsur sistem kepercayaan lokal atau asing yang dianggap dapat menyimpangkan Islam dari keasliannya (1995: 48).

Jargon pondok pesantren sangat terkenal dan telah menjadi motto di berbagai pondok pesantren adalah $\mathrm{Al}$ Muhaafadlotu 'alaa alqodiimisshoolih wal akhdzu bil jadiidil ashla $\underline{h}$ atau memelihara dan melestarikan nilai lama yang baik dan mengambil nilai-nilai baru yang lebih baik. Motto ini selalu terpampang di halaman paling depan pondok pesantren atau dalam bilik-bilik santri. Kekuatan motto tidak sekedar sebuah jargon yang bermakna karakter pesantren salafiyah yang selalu ingin terus berkembang dan berkemajuan, melainkan respons pondok pesantren salafiyah terhadap perkembangan sains dan teknologi serta perkembangan kebijakan Pemerintah dalam dunia pendidikan. Menurut Azyumardi Azra, pesantren bukan hanya mampu bertahan tetapi lebih dari itu yaitu mampu mengembangkan diri dan bahkan kembali menempatkan diri pada posisi yang penting dalam sistem pendidikan nasional Indonesia secara keseluruhan (Madjid, tt; xxiv-xxv).

Kesadaran pondok pesantren salafiyah terhadap fenomena berkembangnya lembaga pendidikan di Indonesia muncul seiring dengan tuntutan santri dan orang tua santri 
yang menginginkan ijazah formal bagi santrinya. Sementara itu, berdirinya pondok pesantren modern maupun lembaga pendidikan model boarding school yang mengadopsi sistem pesantren berkembang cukup pesat. Oleh karena itu, apabila pondok pesantren salafiyah tidak mengikuti perkembangan lembaga pendidikan formal, maka keinginan orang tua untuk memondokan anaknya akan semakin berkurang dan lambat laun pondok pesantren salafiyah kekurangan santri.

Tuntutan zaman dengan berbagai dinamika dalam kebijakan pendidikan menuntut pondok pesantren salafiyah harus mampu beradaptasi dan pada saat yang sama pondok pesantren salafiyah juga harus tetap tidak kehilangan jati dirinya sebagai pusat kaderisasi ulama. Dari aspek pengalaman, pondok pesantren salafiyah cukup akomodatif untuk mengikuti irama perkembangan zaman terutama terkait dengan dunia pendidikan. Bahkan semakin memiliki daya saing dengan model pendidikan formal yang ada karena sudah memiliki kepercayaan sebagai lembaga pendidikan yang membangun karakter santri dengan karakter yang agamis. Pondok pesantren sering dengan lembaga pendidikan yang "tahan banting" karena kemampuannya beradaptasi dalam situasi dan kondisi seperti apapun.

Dinamika perkembangan lembaga pendidikan di Indonesia mengalami pertumbuhan yang masif dan Pemerintah terus menumbuhkembangkan lembaga pendidikan yang berorientasi pada persaingan global. Akibat dari fenomena ini, masyarakat diberi banyak alternatif 
pilihan untuk menyekolahkan anaknya dan pada sisi yang lain pemerintah dengan mudah menyusun regulasi untuk memberikan kesempatan seluruh elemen masyarakat membangun dan menyelenggarakan lembaga pendidikan formal. Berbagai regulasi penyelenggaraan pendidikan formal ini direspons positif oleh pondok pesantren karena telah memiliki santri sebagai model input peserta didik. Namun demikian, beberapa pondok pesantren salafiyah memiliki kekhawatiran karena pondok pesantren adalah penyelenggara pendidikan sekaligus pencetak kader ulama.

Berbagai tantangan pondok pesantren dalam penyelenggaraan lembaga pendidikan formal dijawab dengan mengadakan "penyesuaian". Namun demikian, penyesuain tersebut harus disesuaikan dengan kebutuhan santri, orang tua santri, dan masyarakat secara lebih luas. Di antara respons pondok pesantren salafiyah terhadap regulasi pemerintah dan keinginan santri dan masyarakat lebih luas adalah dengan membuka program Paket $\mathrm{B}$ atau $\mathrm{C}$ dan juga membuka sistem Muadalah. Program Paket B dan C serta Mu'addalah ternyata berdampak positif, seperti alumni pesantren sudah dapat mengikuti kompetisi untuk mengikuti tes menjadi Pegawai Negeri Sipil (ASN) dan dapat masuk menjadi pengurus partai politik dan dapat mengikuti pemilihan umum menjadi anggota dewan. Penyesuaian ini ternyata terus berlanjut sesuai dengan regulasi yang ditetapkan oleh Pemerintah, baik Kementerian Agama maupun Kemendiknas. 
Program paket B dan paket C bagi pondok pesantren salafiyah tidak terlalu sulit karena hanya mengikuti pembelajaran yang tidak banyak menyita waktu. Program ini menjadi sangat populer setelah Menteri Kelautan (Susi Pujiastuti) adalah salah satu peserta yang lulus program paket C. Hal ini berbeda dengan sistem Mu'addalah yang diberikan pada santri pondok pesantren karena telah mengikuti pendidikan di pondok pesantren salafiyah dalam waktu yang cukup lama dan telah menyelesaikan beberapa kitab yang distandarkan oleh Kementerian Agama. Model Mu'addalah merupakan model yang dianggap paling ideal bagi santri pondok pesantren salafiyah untuk memperoleh ijazah formal yang disetarakan dengan ijazah sekolah umum sekaligus sebagai pengakuan pondok pesantren salafiyah oleh negara.

Model ideal $M u^{\prime}$ addalah adalah model yang disambut positif dengan gegap gempita. Hal yang menjadi daya tarik secara substansial adalah khitthah pondok pesantren salafiyah sebagai lembaga pendidikan keagamaan yang memiliki kekhasan tersendiri, yaitu mencetak kader ulama terus dipertahankan. Bahkan lulusan Mu'addalah mampu menduduki kursi dewan dan menjadi kepala Daerah (Bupati) di beberapa tempat, seperti Bupati Kabupaten Demak Jawa Tengah. Keberhasilan model Mu'addalah ternyata tidak dapat berlangsung lama karena Kementerian Agama RI mengeluarkan regulasi baru yang diharapkan lebih memacu pondok pesantren salafiyah bukan saja untuk bersaing dalam

\section{6 | Pendidikan Diniyah Formal}


dunia Pemerintahan dan Dewan, akan tetapi berkompetisi memasuki dunia Perguruan Tinggi.

Akomodasi dari Pemerintah khususnya Kementerian Agama RI adalah dengan memberikan alternatif baru yaitu membuka Pendidikan Diniyah Formal (PDF) sebagai langkah konstruktif dalam dunia pendidikan. Hal ini tertuang dalam Peraturan Menteri Agama (PMA) Nomor 13 tahun 2014 tentang Pendidikan Keagamaan Islam. PMA ini merupakan turunan atas Peraturan Pemerintah (PP) Nomor 55 tahun 2007 tentang Pendidikan Agama dan Keagamaan. Langkah ini menjadi "angin segar" bagi dunia pesantren yang tetap mempertahankan tradisi lama dengan tetap memelihara dan melestarikan nilai-nilai lama melalui kitab kuning akan tetapi membuka dan menerima nilai-nilai baru melalui pendidikan umum. Melalui PDF ini pondok pesantren tidak kehilangan jati dirinya sebagai lembaga pencetak para ulama sekaligus lembaga pewaris ilmu karya ulama salaf. Hal ini sesuai dengan yang disampaikan Kasubdit Pendidikan Diniyah Ahmad Zayadi, bahwa "PDF pada berbagai tingkatan ini merupakan jenis layanan pendidikan keagamaan Islam yang bersifat formal. Karena pendidikan keagamaan Islam, maka tujuannya untuk mencetak para kader ulama yang ahli di bidang ilmu agama Islam". http://www.ponpesmanggisan. com/manggisan/berita-165-pesantren-yangmenyelenggarakan-pendidikan-diniyah-formal.html diupload tanggal 30 Mei 2018. 
Berangkat dari regulasi dibukanya PDF di pondok pesantren salafiyah ini, diperlukan kajian secara mendalam melalui penelitian tentang bagaimana implementasinya dan bagaimana bentuk kaderisasi ulama yang dikembangkan pondok pesantren melalui PDF. Penelitian ini diperlukan karena PDF merupakan program yang dimulai tahun 2014 dan baru meluluskan santri sebagai angkatan pertama. Di samping itu, penelitian untuk meyakinkan bahwa pendidikan diniyah yang selama ini berjalan di pondok pesantren salafiyah dapat menjadi lembaga pendidikan formal. Apakah dengan model PDF menjadikan kader ulama terjadi pergeseran yaitu menjadi lebih toleran karena menerima mata pelajaran umum? Inilah beberapa pertanyaan yang terus perlu dikaji.

Untuk mempersempit kajian dan lebih fokus pada pembahasan, maka rumusan masalah yang menjadi inti pengkajian adalah 1) Bagaimana implementasi Pendidikan Formal berbasis pesantren dalam bentuk Pendidikan Diniyah Formal (PDF)?, dan 2) Bagaimana bentuk kaderisasi ulama toleran melalui PDF pada tingkat Ulya di Pondok pesantren Assalafi Al Fithrah Kota Surabaya? Adapun tujuan penelitian secara umum adalah untuk mengetahui secara lebih komprehensif tentang implementasi PDF Ulya Al Fithrah di Pondok Pesantren Assalafi Al Fithrah Kota Surabaya dalam mencetak kader ulama yang toleran. Tujuan secara lebih mendetail dalam penelitian ini adalah untuk 1) Untuk mengetahui secara lebih mendalam dan komprehensif

8 | Pendidikan Diniyah Formal 
tentang implementasi Pendidikan Diniyah Formal (PDF) Ulya Al Fithrah, dan 2) Untuk mengetahui bentuk kaderisasi ulama yang toleran yang dibentuk melalui PDF Ulya Al Fithrah di Pondok pesantren Assalafi Al Fithrah Kota Surabaya.

\section{口 PENDIDIKAN DINIYAH FORMAL; KAJIAN YANG MASIH TERBATAS}

Pendidikan Diniyah Formal (PDF) merupakan lembaga pendidikan yang diselenggarakan oleh pondok pesantren salafiyah dengan persaratan tertentu, baik persaratan administrasi, teknis, maupun kelayakan sesuai aturan. Persaratan secara administrasi diantaranya adalah memiliki ijin operasioanl dari Kementerian Agama Kabupaten/Kota, merupakan organisasi nirlaba yang berbada hukum, memiliki AD/ART, struktur organisasi/Pengurus, dan memiliki santri yang mukim dan belajar pada pesantren yang bersangkutan paling sedikit 300 (tigaratus) orang pada setiap tahun selama 10 (sepuluh) tahun pelajaran terahir. Jumlah santri 300 (tigaratus) orang ini merupakan jumlah minimal yang benar-benar mukim pada 1 (satu) pesantren.

Persaratan teknis berkaitan dengan pesantren sebagai penyelenggaran pendidikan diniyah formal, satuan pendidikan formal (Rekomendasi dan struktur organisasi, Jumlah/Persentase dan kualifikasi pendidik dan tenaga kependidikan, memiliki calan peserta didik, kurikulum, manajemen dan proses pendidikan, sistem evaluasi 
pendidikan, sumber pembiayaan, dan sarana dan prasarana) serta rencana induk pengembangan). Persaratan kelayakan adalah persaratan kelayakan izin pendirian Pendidikan Diniyah Formal. (Keputusan Dirjen Pendidikan Islam Nomor 5839 Tahun 2014). Adapun PDF yang diselenggarakan oleh pondok pesantren salafiyah adalah 3 tingkatan, yaitu PDF tingkat Ula (setingkat MI/SD), Wustho (setingkat MTs/SMP), dan Ulya (setingkat MA/SMA/SMK).

Dengan adanya persaratan yang harus dipenuhi oleh pondok pesantren salafiyah untuk menyelenggarakan PDF cukup ketat, maka tidak semua pondok pesantren mampu menyelenggarakan. Di seluruh Pondok pesantren salafiyah yang ada di Indonesia hanya beberapa yang mampu menyelenggarakan PDF wustho dan ulya. Di antara PDF yang telah berjalan dan memiliki legalitas formal dari Kementerian Agama adalah sebagai berikut.

1. PDF Wustho Malindo Manbaul Ulum Pekalongan, Jawa Tengah.

2. PDF Wustho Al-Munawaroh Pekanbaru, Riau

3. PDF Wustho Apik Kaliwungu, Kendal, Jawa Tengah

4. PDF Wustho Minhaajurrasyidiin, Lubang Buaya, Jakarta Timur.

5. PDF Wustho Al-Fitrah Surabaya, Jawa Timur.

6. PDF Wustho Nurul Qadim, Probolinggo, Jawa Timur.

7. PDF Wustho dan PDF Ulya Al-Mubarok, Wonosobo, Jawa Tengah.

8. PDF Ulya Salafiyah Parake, Polewali Mandar, Sulawesi Barat. 
9. PDF Ulya Minhaajurrasyidiin, Lubang Buaya, Jakarta Timur.

10. PDF Ulya Al-Falah, Jepara, Jawa Tengah.

11. PDF Wustho Al-Fitrah Surabaya, Jawa Timur

12. PDF Ulya Al-Munawaroh, Pekanbaru, Riau.

13. PDF Ulya Malindo Manbaul Ulum Pekalongan, Jawa Tengah.

Dinamika perkembangan lembaga pendidikan formal yang berada dalam lingkup pondok pesantren salafiyah murni biasanya mengalami tarik menarik untuk menyelenggarakan pendidikan formal. Hal ini dikarenakan pada satu sisi harus tetap melestarikan kitab kuning yang diajarkan sekaligus menjadi pewaris ulama salaf dan keinginan pendiri pondok pesantren. Sementara itu apabila menyelenggarakan pendidikan formal harus mengikuti aturan Pemerintah dengan berbagai administrasi dan kurikulum yang harus terpenuhi. Dari dua hal ini, pondok pesantren assalafi al Fithrah mampu mengadaptasikan antara pondok pesantren salafiyah murni dengan model lembaga pendidikan formal dengan mengikuti regulasi Pemerintah. Hal ini sesuai dengan motto yang ada di pondok pesantren yaitu Al Muhaafadlotu 'alaa alqodiimisshoolih wal akhdzu bil jadiidil ashla $\underline{h}$ yaitu tetap mempertahankan kitab kuning sebagai rujukan pembelajaran sekaligus tetap menerapkan model sorogan dan bandongan sebagai ciri dari pondok pesantren salafiyah dan menerima sesuatu yang baru yang baik. Sementara itu, dengan PDF berarti mempunyai 
konsekuensi membuka pembelajaran dengan mata pelajaran umum sesuai dengan peraturan Pemerintah dan pembelajaran dengan metode pembelajaran sebagaimana pada sekolah formal pada umumnya.

Secara umum kajian dan penelitian tentang Pendidikan Diniyah Formal (PDF) belum banyak dilakukan. Hal ini dikarenakan 1). regulasi penyelenggaraan program PDF ditetapkan pada tahun 2014 dengan Peraturan Menteri Agama (PMA) Nomor 13 tahun 2014 tentang Pendidikan Keagamaan Islam, 2) Belum semua pondok pesantren salafiyah menyelenggarakan program PDF, dan 3) Lulusan PDF tingkat Ulya yang pertama tahun ajaran 1438 H/ 1439 H. atau ajaran 2018 M. /2019 M. Namun demikian, untuk memperkaya dalam penelitian ini terdapat beberapa kajian yang telah dilakukan oleh para peneliti pondok pesantren.

Di antara tulisan yang memiliki sedikit ketersinggungan dengan penelitian yang dilakukan adalah tulisan Aswan yang dimuat dalam jurnal Falasifa, Vol. 7 Nomor 1 Maret 2016 terbit STAI Al Falah Assunniyyah Jember. Judul artikel "Integrasi Pendidikan Formal Dan Pendidikan Diniyah Salafiyah Terhadap Santri Assunniyyah Kencong Jember Sebagai Antisipasi Ouput Pesantren Di Era Regulasi Pendidikan Nasional". Artikel ini menekankan pada regulasi tentang integrasi sistem pendidikan di pondok pesantren Assunniyyah sebagai pesantren murni salaf akan tetapi dalam bidang kurikulum ditunjang dengan sistem yang sudah modern/formal klasikal dan telah terjadi integrasi 
melalui kurikulum dan pembelajaran tradisional dari pola pengajaran sorogan, bandongan, wetonan dan muhafazhah/ hafalan sebagai syarat kenaikan kelas santri sampai pada pola klasikal dengan penjenjangan.

Tulisan kedua yang mencoba "membedah" ketradisionalan Pesantren dari persoalan kultur, tradisi, dan pemikiran adalah tulisan Mochammad Achyat Ahmad dengan judul Liberalisasi Islam di Pesantren. Dari tulisan tersebut bahwa setelah pesantren banyak melakukan pergeseran-pergeseran penting dari tradisionalisme ke modernisme berdampak pada tidak terdapatnya perbedaan dengan penerapan sistem pendidikan modern. Hal ini karena pesantren harus maju mengikuti perkembangan zaman dan realitasnya sistem dan produk pesantren relatif dapat bersaing dengan dunia luar. Di sinilah pesantren ketika melakukan penyesuaian-penyesuaian sistem adalah sebuah keniscayaan meskipun tidak berarti harus menghilangkan identitas diri atau abai terhadap karakter dan status asalnya.

Penelitian yang langsung terkait dengan PDF Ulya Al Fithrah telah dilakukan oleh beberapa Mahasiswa Perguruan Tinggi Islam di Surabaya sebagai tugas penyusuna Skripsi. Di antara penelitian tersebut adalah tentang efektivitas Cognitive Behavior Therapy Dalam Meningkatkan SelfRegulated Learning Santri Kelas Isti'dad Ulya B (Kelas Persiapan) di Pondok Pesantren Assalafi Al Fithrah oleh Muhammad Ulil Absor. Hasil penelitian bahwa konseling dengan Cognitive Behavior Therapy Dalam Meningkatkan 
Self-Regulated Learning Santri Kelas Isti'dad Ulya B (Kelas Persiapan) di Pondok Pesantren Assalafi Al Fithrah melalui 5 (lima) tahapan yaitu identifikasi, diagnosisis, prognosis, treatment, dan follow up.

Penelitian berikutnya adalah tentang Pengaruh Mindfullness Therapy dalam Meningkatkan Regulasi Emosi Santriwati Kelas Isti'dad Pendidikan Diniyah Formal (PDF) Ulya Pondok Pesantren Assalafi Al Fithrah. Penelitian yang dilakukan oleh Tri Anita Jumaroh menyimpulkan bahwa penggunaan Mindfullness Therapy berpengaruh dalam meningkatkan regulasi emosi santriwati kelas Isti'dad Ulya di Pondok Pesantren Assalafi Al Fithrah Surabaya. 


\section{Bab II \\ PONDOK PESANTREN: LEMBAGA PENDIDIKAN TAFAQQUH FI ADDIEN}

Kajian pondok pesantren selalu mengalami perkembangan seiring dengan dinamika pondok pesantren dalam mengikuti "irama" peradaban bangsa. Pondok pesantren salafiyah dituntut untuk tetap mempertahankan tradisi penguasaan kitab kuning (kutub at-turats) sebagai sumber pendidikan agama dan juga dituntut untuk beradaptasi dengan pola pendidikan yang dikembangkan oleh Pemerintah yang notabene lebih mengedepankan pendidikan umum. Dualisme orientasi dalam aspek pendidikan antara kepentingan pondok pesantren salafiyah dengan Pemerintah membutuhkan "penyatuan", sehingga kedua kepentingan tersebut dapat terakomodasi. Pondok pesantren tetap berjalan sesuai dengan tujuan utamanya sebagai lembaga pencetak kader ulama sekaligus mengakomodir model pendidikan umum yang menjadi 
regulasi Pemerintah. Ja;an keluar biasanya 70\% kurikulum pendidikan keagamaan Islam dan 30\% Pendidikan umum atau dengan membuka program B setingkat MTs/SMP dan atau paket $C$ setingkat MA/SMA.

Sementara itu, dalam dunia pondok pesantren juga mengalami pergeseran orientasi kelembagaan. Pergeseran ini paling tidak terlihat dalam pengembangan model pondok pesantren, yaitu;

1. Pengembangan kelembagaan pendidikan model pesantren salafiyyah murni dengan membuka sekolah formal berbasis pendidikan umum. Contoh model pesantren ini adalah Ponpes Al Hikmah Benda Sirampog Jawa Tengah yang membuka sekolah formal berbasis pendidikan umum.

2. Pengembangan kelembagaan pendidikan model pesantren salafiyyah murni dengan membuka sekolah formal berbasis pendidikan keagamaan Islam (madrasi). Contoh model pesantren ini adalah Ponpes Al Fithrah yang berpusat di Kedinding Kota Surabaya.

3. Mendirikan pondok pesantren modern yang memadukan dua unsur sekaligus yaitu menyelenggarakan pendidikan umum akan tetapi juga tidak menyampingkan pendidikan keagamaan Islam yang bersumber dari kitab kuning,

Pergeseran orientasi pondok pesantren merupakan jawaban pondok pesantren terhadap keinginan santri dan orang tua santri agar setelah selesai mondok dapat 
melanjutkan ke Perguruan Tinggi. Bagi pondok pesantren seperti pondok modern Gontor tidak lagi membuka sekolah formal karena ijazah dari Ponpes Gontor telah diakui Pemerintah dan Perguruan Tinggi, sehingga alumninya dapat tidak memerlukan lagi ijazah formal. Sebenarnya pondok pesantren salafiyah juga dapat menggunakan Sistem Mu'addalah sehingga tidak perlu lagi membuka lembaga pendidikan formal.

Meskipun varian model penyelenggaraan pondok pesantren semakin banyak akan tetapi secara prinsip memiliki tujuan tunggal yaitu sebagai lembaga tafaqquh $f i$ addien. Disinilah pesantren punya keunggulan-keunggulan yang tak dimiliki oleh sistem pendidikan lain (Ahmad, 1434;25). Namun demikian, tetap saja pergeseran orientasi pondok pesantren salafiyah (tradisional) ke khalafiyah (modern) berdampak pada karakter yang dibangun dari kepatuhan kepada Kiai (ta'dhim wal ikhtiroom), kesederhanaan yang mencontoh figur Kiai, akhlak terhadap teman sesama santri, serta berpegang atau merujuk pada ulama salafussholih ikut tereduksi, sehingga harapan orang tua untuk menjadikan anaknya tafaqquh fi ad-din sulit terpenuhi.

Terjadinya pergeseran dalam dunia pendidikan di pondok pesantren salafiyah merupakan keniscayaan, meskipun beberapa pondok pesantren tetap mempertahankan ke-salafiyah-annya, seperti pada pondok salafiyah yang didalamnya juga mengkhususkan pada tahfidzul qur'an. Bagi pondok pesantren salafiyah yang adaptif dengan 
lembaga pendidikan yang sedang berkembang akan mengalami inovasi-inovasi dalam berbagai aspek secara kelembagaan. Inovasi ini tidak selalu menggerus atau menghilangkan pondok pesantren salafiyah karena bisa saja tetap pada garis ideologinya yaitu mempertahankan kajian kitab kuning karya ulama salaf sebagai inti pembelajaran.

Diversifikasi yang terjadi pada pondok pesantren salafiyah pada tataran kelembagaan bukan pada pengkajian sehingga ketika pondok pesantren dikenal dengan salah satu keilmuan maupun tradisi tertentu akan tetap dipertahankan meskipun telah menyelenggarakan lembaga pendidikan formal. Sebagai contoh pondok pesantren yang mengkaji kitab-kitab khusus seperti fikih, hadits, tasauf, tafsir akan tetap dikenal sebagai pondok dengan spesialisasi kitab fikih, hadits, tasauf, tafsir. Begitu juga tradisi yang dikembangkan pondok pesantren seperti thariqah sehingga dikenal terdapat pondok pesantren toriqoh.

Berbagai bentuk perubahan yang terjadi di pondok pesantren salafiyah dan tetap mempertahankan watak keasliannya menurut Nurcholis madjid bahwa pondok pesantren secara historis tidak hanya identik dengan makna keislaman, tetapi juga mengandung makna keaslian Indonesia (indigenous) sehingga tidak bisa dipungkiri bahwa pesantren adalah sebuah lembaga sistem pendidikanpengajaran asli Indonesia yang paling besar dan mengakar kuat (Madjid,1997: 3). Namun demikian, watak keaslian ini 
tetap membuka atau menerima sistem pendidikan modern yang diusung oleh Belanda sebagai negara penjajah.

Dalam sejarah, keterbukaan pondok pesantren menerima sistem pendidikan modern diawali oleh pondok pesantren Mambaul Ulum di Surakarta yang berdiri tahun 1906. Menurut Nurcholis Madjid Pesantren Mambaul Ulum mengambil tempat paling depan dalam merambah bentuk respon pesantren terhadap eskpansi pendidikan Belanda dan pendidikan Islam modern. Rintisan ini diikuti oleh pesantren Tebuireng pada tahun 1916 mendirikan Madrasah Salafiyah yang tidak hanya mengadopsi sistem pendidikan modern, tetapi juga memasukkan beberapa pelajaran umum seperti berhitung, bahasa Melayu, ilmu bumi, dan menulis dengan huruf latin ke dalam kurikulumnya (Madjid, 1997: xvii).

\section{口 INDIGENOUS PONDOK PESANTREN SALAFIYAH}

Watak keaslian pondok pesantren salafiyah sejak berdiri sampai sekarang tidak bergeser yaitu sebagai lembaga pendidikan yang mencetak kader ulama, fokus pada kajiankajian kitab salafiyah karya ulama salaf, dan tetap menjunjung tinggi khazanah keilmuan agama yang terpersonifikasi pada sosok Kiai sebagai pimpinan pondok pesantren. Menurut Chirzin setiap pesantren salafiyah memiliki ciri khas dalam penekanan yang menunjukan ketidak seragaman merupakan ciri pesantren salaf sekaligus tanda atas kebebasan dari tujuan pendidikan (Wahjoetomo; 1997: 84). 
Ketidak seragaman pondok pesantren salafiyah menurut hemat penulis terjadi pada beberapa hal, yaitu 1) Orientasi pesantren cukup beragam seperti ada pesantren yang menguatkan pada thariqah, akhlak-tasawuf, fiqh, dan tahfidz, 2) Konsekuensi dari perbedaan orientasi menjadikan kitab yang dipelajari tidak sama antar satu pesantren dengan pesantren lainya, 3) Perbedaan kitab akan berpengaruh pada sikap dan perilaku santri sehingga terdapat santri dengan tingkat keta'dhiman berbeda antara satu santri ponpes dengan santri ponpes lainnya, seperti terdapat santri sufi, santri thariqat, santri ahli fiqh, dan santri yang kuat mengedepankan rasionalitas, 4) Perbedaan perilaku santri juga berefek pada adanya santri yang berani mengadakan demonstrasi (paling tidak keluar dari Pesantren) dan kebanyakan santri menerapkan pola sam'an, wa tho'atan, tashdiq, wal ikhtiroom.

Pergeseran dalam membuka sistem pendidikan di pondok pesantren salafiyah juga ada yang diawali dengan membuka madrasah salafiyah. Pondok pesantren ini menerapkan sistem klasikal dan membuka mata pelajaran umum. Sistem ini meningkat menjadi sistem madrasi ketika terdapat kenaikan kelas bukan sekedar pada kenaikan kitab dan meningkat pada bentuk-bentuk sekolah. Dalam beberapa kebijakan mengikuti kebijakan Pemerintah, seperti mengikuti sistem mu'addalah, Paket B atau C, dan yang terahir adalah dengan mengikuti sistem PDF (Pendidikan Diniyah Formal). 
Terjadinya pergeseran pondok pesantren yang melibatkan dalam dunia pendidikan formal tidak menggeser tujuan pondok pesantren (salafiyah) sebagai pusat kajian kitab kuning. Di sinilah salah satu watak indegenous pondok pesantren salafiyah yang tetap bertahan sekalipun perkembangan lembaga pendidikan mengalami lompatan paradigma mengikuti perkembangan global. Pondok pesantren seolah tidak pernah mengalami keresahan untuk mengembangkan kreatifitas pendidikan agar tetap memperoleh tempat yang diminati oleh masyarakat. Bahkan sebaliknya, model pendidikan ala pondok pesantren menjadi rujukan bagi pengembangan lembaga pendidikan baru dengan sistem boarding school.

Era modernitas bukan saja menuntut pondok pesantren salafiyah beradapatasi dan bersaing dengan lembaga pendidikan keagamaan modern, akan tetapi membuka cakrawala baru terutama dalam bidang teknologi informatika. Pembelajaran kitab kuning dapat dilakukan dengan menggunakan sarana dan prasarana digital dan berlangsung kapan saja dan dimana saja yang penting masih terjangkau oleh jaringan internet. Geliat pondok pesantren salafiyah memanfaatkan teknologi digital menjadi hal yang biasa, apalagi beberapa kitab kuning sudah tercetak dalam bentuk digital.

Akibat dari teknologi digital yang merambah pada tercetaknya kitab kuning dalam bentuk digital akan terus 
dikembangkan. Kalau sudah demikian, apakah watak indigenous pondok pesantren salafiyah akan hilang atau minimal semakin berkurang dan mungkinkan tidak ada lagi istilah kitab kuning karena sudah tergantikan dengan media digital? Berbagai spekulasi dan konsekuensi akan terus menjadi bahan pemikiran bagi pondok pesantren salafiyah. Spekulasi yang mungkin muncul adalah tercerabutnya kitab kuning dalam bentuk lembaran yang ditenteng ketika akan mengaji dan hilangnya model pemaknaan menggantung pada kitab dalam bahasa khas Pesantren salafiyah yaitu bahasa Jawa.

Konsekuensi berada dalam peradaban yang serba digital, pondok pesantren mau tidak mau harus mampu menghadapi dan menggunakan teknologi tersebut. Konsekuensi ini sebenarnya telah dipredeksi sejak awal yaitu dengan adanya motto yang hampir selalu ditampilkan di ruang-ruang publik pondok pesantren salafiyah yaitu memelihara dan melestarikan nilai lama yang baik dan mengambil nilai-nilai baru yang lebih baik. Era digital adalah era baru yang memiliki nilai kebaikan untuk diterapkan dalam pembelajaran saat ini.

\section{$\square$ PESANTREN; SEJARAH DAN ORIENTASI PEN- DIDIKAN}

Pondok pesantren pada awal berdirinya merupakan lembaga yang mencetak kader ulama sehingga dikenal dengan pencetak majikan. Hal ini dikarenakan lulusan pondok pesantren dalam sejarahnya selalu mengarahkan 
para santrinya memiliki kemampuan agama yang bersumber dari kitab-kitab karya ulama salaf bukan menjadi pegawai pemerintah. Bahkan dalam beberapa pesantren sebagai pusat perlawanan terhadap penjajah dan beberapa ajaran "berseberangan" dengan pemerintah.

Sejarah mencatat bahwa Pesantren sebagai pusat perlawanan terhadap penjajah karena awal berdirinya pondok pesantren pada saat bangsa ini mengalami penjajahan. Pesantren sebagai perlawanan terhadap penjajah tidak hanya dalam bentuk perlawan fisik, melainkan semangat yang kuat untuk mempertahankan negara sebagai negara yang merdeka dan bebas dari penjajah. Perlawanan pondok pesantren merata di berbagai daerah terutama di Jawa Timur dengan basis pesantren yang kuat. Bahkan untuk memotivasi dan membangkitkan semangat perjuangan diciptakan syair lagu, yaitu Yaa ahlal wathon karya Kiai Wahab. Syair yang sangat fenomenal tersebut adalah sebagai berikut.

Yaa aflal wathon yaa aflal wathon Yaa ahlal wathon

Hu66ul wathon minal iman

Walaa takun minal hirmaan

Inhadluu Ahlad Wathon (dua Kali)

Induunisiyyaa Bülaadii

Anta 'Vnwaanul Faßhomaa

Kullu Man Ya'tiika Yaumaa

Toomihan Yalqi Himaamaa 
Pusaka hati wahai Tanah Airku

Cintamu dalam imanku

Jangan halangkan nasibmu

Bangkitlah, hai, Bangsaku

\section{Indonesia negeriku \\ Engkau panji martabatku \\ Siapa datang mengancammu \\ 'Kan binasa di bawah dulimu}

Kelahiran pondok pesantren sebagai benteng dari kekuatan moral dan bersumber dari ajaran agama tetap saja tidak mengalami pergeseran orientasi yaitu sebagai lembaga pendidikan tradisional dengan kajian kitab kuning. Karakter ini (terutama pondok pesantren salafiyah) sampai sekarang tetap dipertahankan seperti pondok pesantren sehingga kemandirian setelah santri lulus dari pondok pesantren dapat dijadikan model bagi lembaga pendidikan. Pondok pesantren menciptakan suasana kelembagaan yang serba mandiri seperti memasak dan mencuci serta membentuk pola kehidupan yang sederhana. Model kehidupan seperti ini denga sendirinya akan membentuk karakter santri yang mandiri dan biasa bekerja sendiri dan tetap pada tujuan utamanya, yaitu memperdalam ilmu-ilmu agama. Lulusan pesantren sebagian besar bekerja di sektor swasta daripada menjadi pegawai negeri. Menurut A. Mukti Ali (1987: 20), Pondok pesantren bukanlah suatu lembaga pendidikan untuk mencetak "pegawai" yang mau diperintah oleh orang 
lain akan tetapi lembaga pendidikan yang mencetak "majikan" untuk dirinya sendiri. Pesantren mencetak generasi yang tetap istiqomah dalam pengembangan intelektual yang didasarkan pada kitab kuning.

Pondok pesantren memiliki kekuatan tetap mempertahankan tradisi kepesantrenan termasuk tradisi pengelolaan dengan kurikulum khusus yaitu kitab kuning. Sejarah mempertahankan kitab kuning sebagai satu-satunya sumber rujukan pembelajaran sekaligus sebagai kurikulum inti adalah satu sisi "genre" pesantren. Akan tetapi menerima model lembaga pendidikan kekinian yang berkembang seirama dengan perkembangan zaman dan tuntutan modernitas merupakan bentuk "kelenturan" dalam mengakomodasi tuntutan tersebut. Jargon Almukhaafdlotul -'alal qaadiimisshalih Walakhdzu biljadidiil ashlakh menjadi jargon yang sangat populer. Jargon yang diambil dari kaidah ushul Fiqih ini tidak mengurangi substansi pembelajaran kitab kuning.

Secara substansi pengembangan pondok pesantren dengan mengadopsi model pendidikan formal lebih terstruktur, akan tetapi nilai-nilai tradisi yang berlaku akan mengalami pergerseran, seperti dari model sorogan yang mengedepankan pembelajaran face to face antara santri dengan Kyai bergeser menjadi kalsikal yang diatur dalam pola kelas dan tingkatan kelas. Padahal dalam pembelajaran sorogan terdapat nilai tidak sekedar pada substansi kitab yang dibaca akan tetapi pada ikatan antara santri dengan 
Kyai yang lebih dekat karena terjadi dialog individual. Sementara pembelajaran di kelas tidak akan sedekat secara pribadi antara santri dengan ustad karena pembelajaran dilakukan dengan kelompok.

Tuntutan pesantren untuk mengadopsi model pembelajaran klasikal secara otomatis tidak dapat dinafikan terjadinya pergeseran orientasi Pendidikan. Dalam pengamatan penulis bahwa pergeseran orientasi terjadi minimal seperti 1), pembelajaran ditentukan dengan waktu yang rigit, 2) adanya standar lulusan yang harus dicapai sesuai dengan regulasi pemerintah (Kementerian Agama), 3) adanya struktur kurikulum yang baku baik kurikulum pesantren maupun kurikulum pemerintah, 4) pembatasan waktu belajar karena tingkatan kelas dan kelulusan santri, 5) adanya nilai kuantitatif sebagai hasil belajar, 6) melakukan evaluasi semesteran, mid semester, dan ulangan harian, dan 7) diperolehnya ijazah formal untuk melanjutkan studi.

Adanya pergeseran orientasi pendidikan dengan mengikuti pola atau regulasi yang ditetapkan oleh Kementerian Agama tidak serta menggeser kualitas santri dalam penguasaan kitab kuning maupun pembentukan karakter santri. Menurut dr Sutomo yang dikutip oleh Dawam Rahardjo (1985: ix-x) ada beberapa hal yang sudah menjadi bagian dari kehidupan santri di pondok pesantren salafiyah yaitu; Pertama, sistem pondoknya di mana pendidik bisa melakukan tuntutan dan pengawasan langsung, kedua, keakraban hubungan antara santri dan kiai 
sehingga bisa memberikan pengetahuan yang hidup, ketiga, pesantren mampu mencetak orang-orang yang bisa memasuki semua lapangan pekerjaan yang bersifat merdeka, keempat, cara hidup para kiai yang sederhana tetapi penuh kesenangan dan kegembiraan, dan kelima, pesantren merupakan sistem pendidikan yang murah biaya penyelenggaraannya untuk menyebarkan kecerdasan bangsa.

Kelima karakter yang dibangun pondok dalam kehidupan santri adalah keunggulan yang sulit mengalami pergeseran. Apalagi pondok pesantren yang memiliki santri cukup banyak dan memiliki figur Kyai sebagai pendiri sekaligus pimpinan pondok pesantren dan menjadi panutan ummat Islam secara umum. Bahkan pergeseran juga tidak terjadi pada sifat santri dengan Panca Jiwa kepesantrenan, yaitu keikhlasan, kesederhanaan, kemandirian, ukhuwah Islamiyah, dan kemerdekaan (Hajar, 2009: 41),

\section{$\square$ KITAB KUNING DI TENGAH TARIK MENARIK KURIKULUM PEMERINTAH}

Kitab kuning bagi pondok pesantren salafiyah adalah "ruh"nya sehingga apabila pondok pesantren tidak mengajarkan kitab-kitab karya ulama salaf tersebut bukan pondok pesantren salafiyah. Penguasaan kitab kuning adalah identitas pengembangan intelektual kaum sarungan yang dijadikan barometer keberhasilan pondok pesantren. Identitas lainya seperti 1) hubungan kekerabatan antara santri dengan kiai, 2) sikap ta'dzimnya santri terhadap kiai 
dengan istilah sam'an wa tho'atan, tashdiq wal ikhtirom (selalu mendengarkan apa yang dikatakan kiai, selalu menaati apa yang diperintah kiai, selalu membenarkan perkataan dan perilaku kiai, dan selalu memuliakan kiai dan keluarganya), 3) kegiatan pembelajaran yang cenderung apa adanya, 4) selalu memakai sarung dan pecis dalam setiap aktivitas apapun, dan 5) pola hidup yang sederhana baik dalam berpakaian maupun memenuhi aktifitas kebutuhan hidup sehari-hari.

Perjalanan kitab kuning sebagai "kurikulum" pokok pondok pesantren salafiyah mendapat "ancaman" apabila menyelenggarakan lembaga pendidikan formal dengan regulasi Pemerintah. Akomodasi kurikulum menjadi keniscayaan meskipun dengan komposisi $70 \%$ kurikulum keagamaan Islam dan 30\% kurikulum umum, padahal apabila santri harus mempelajari mata pelajaran umum maka tuntutan penguasaan kedua kurikulum (Agama dan Umum) harus seimbang. Asumsi ini berlaku bagi pondok pesantren yang menerapkan regulasi dan secara ketat melaksanakan sesuai dengan jadwal pembelajaran. Akan tetapi pondok pesantren salafiyah sebenarnya dapat mensikapi dengan menjadikan 30\% mata pelajaran umum sebagai komplemen karena jurusan yang diterapkan juga bukan jurunsa IPA, IPS dan Bahasa, melainkan jurusan keagamaan Islam.

Beberapa pondok pesantren salafiyah mampu melakukan proses penyelenggaraan lembaga pendidikan formal akan tetapi tidak kehilangan jati dirinya sebagai 
lembaga pendidikan kitab kuning. Menurut Muh. Tolkhah Hasan (1989: 75) Penguasaan santri terhadap kitab kuning pada pondok pesantren salaf selain kemampuan berbahasa Arab secara lisan dan tulisan adalah penguasaan isi kitab kuning. Untuk menguasai kitab kuning tersebut dilakukan secara periodik, yaitu santri diminta untuk membahas kitab kuning dan menjelaskan kedudukan kalimat dan pengertian isinya. Selain itu juga diadakan ujian lisan dan tulisan (Tolkhah, 1989: 75). Artinya bahwa penguasaan kitab kuning tetap dapat dilakukan meskipun santri dibebani 30\% mata pelajaran umum pada sekolah formal yang diselenggarakan. Hal ini dikarenakan pesantren dapat mengatur waktu dan mekanisme ujian apalagi evaluasi atau penilaian seperti ini biasanya dilakukan dengan cukup sederhana, yaitu apabila para santri telah selesai mempelajari kitab kuning sebagai kurikulum yang dipelajari selama belajar dengan kiai dan kiai memperbolehkan untuk mengkaji kitab lain yang lebih tinggi, maka dengan sendirinya tujuan pembelajaran dianggap sudah selesai sesuai dengan tujuannya. Paling tidak santri telah mampu memahami teks kitab kuning yang dibaca (Fahmul Maqru') dan santri mampu menyampaikan isi pikiran dalam bahasa arab secara lisan, dimana orang lain mampu memahami apa yang diucapkan (Ta'bir Syafahi).

\section{$\square$ PDF ULYA PUSAT KADERISASI ULAMA TOLERAN; SEBUAH KERANGKA BERFIKIR}

Kajian Pendidikan Diniyah Formal (PDF) Ulya di Pondok pesantren Assalafi Al Fithrah ini berkaitan dengan implementasi Pendidikan Formal dalam bentuk PDF dengan 
basis pesantren salafiyah dan bentuk kaderisasi ulama toleran yang dibagun melalui PDF Ulya Al Fithrah di Pondok pesantren Assalafi Al Fithrah Kota Surabaya. Secara sederhana, kerangka pikir yang dijadikan alur dalam penelitian ini adalah sebagai berikut.

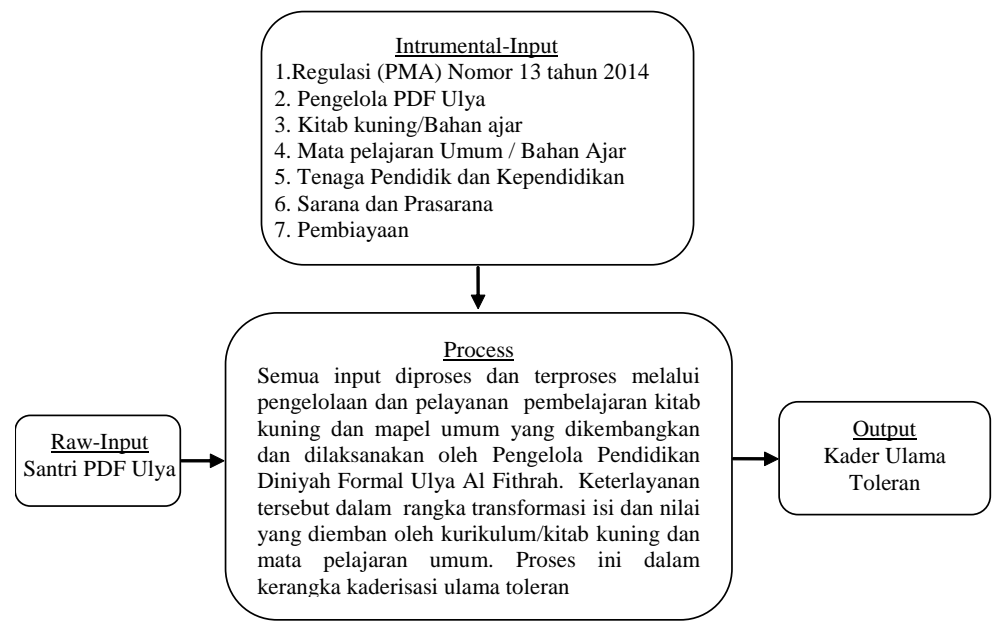

Instrumental input dalam penyelenggaraan PDF Ulya ini merupakan masukan (Input) yang keberadaannya dan pemanfaatannya diatur untuk mencapai hasil pembelajaran yang diharapkan. Regulasi PMA No. 13 tahun 2014 menjadi sangat penting sebagai dasar dalam penyelenggaraan PDF. Begitu juga Pengelola, kitab kuning dan mata pelajaran umum sebagai bahan ajar, tenaga pendidik dan kependidikan, sarana dan prasarana dan pembiayaan. Keseluruhan instrumen tersbut menjadi sangat urgen mencapai hasil yang diharapkan. Raw input merupakan kualitas santri yang akan mengikuti proses pendidikan di PDF Ulya Al Fithrah. Kualitas 
input ini didasarkan pada pola Isti'dadiyah sebelum mengikuti proses pembelajaran di kelas PDF Ulya bagi santri alumni MTs atau SMP, sedangkan alumni dari PDF Wustho bisa langsung mendaftar ke PDF Ulya. Out Put

Proses pembelajaran PDF Ulya Al Fithrah merupakan kegiatan yang melibatkan seluruh komponen pembelajar sehingga bagi peserta didik memperoleh keterlayanan pendidikan yang optimal. Diantara yang memiliki peran terhadap keterlayanan peserta didik adalah kepemimpinan kepala PDF Ulya, Manajemen pengelolaan, membangun budaya yang sesuai dengan karakter pondok pesantren salafiyah, adanya team work yang solid untuk mendukung jalanya pembelajaran, adanya kemandiri pengelola, dan adanya evaluasi pembelajaran. Output merupakan keluaran yang dihasilkan dari proses pembelajaran selama di PDF Ulya Al Fithrah. Output ini memiliki dua dimensi, yaitu yang diharapkan dan tidak diharapkan. Output yang diharapkan adalah menjadi kader ulama penerus ulama salafussholih dan yang tidak diharapkan adalah keluar dari jalur tersebut.

\section{口 METODOLOGI DAN TEKNIK ANALISIS DATA}

Buku ini merupakan hasil penelitian dan yang menjadi lokus penelitian adalah PDF Ulya Al Fithrah. Penetapan ini didasarkan pada PDF Ulya Al Fithrah telah meluluskan santri pada tahun ajaran 1438 H. / 1439 H. sebagai lulusan pertama dan alumni telah melanjutkan studi ke Perguruan Tinggi Negeri maupun swasta. Disamping itu, pelaksanaan 
pembelajaran model PDF Ulya Al Fithrah telah didasarkan pada Peraturan Menteri Agama (PMA) Nomor 13 tahun 2014 tentang Pendidikan Keagamaan Islam, baik dari aspek kurikulum maupun manajemen PDF.

Alasan Pemilihan PDF Ulya Al Fithrah juga didasarkan pada beberapa hal, yaitu 1) PDF Ulya Al Fithrah merupakan satu-satunya PDF yang berada di Kota Surabaya meskipun terdapat banyak Pondok Pesantren salafiyah yang memiliki santri lebih dari 300 santri dalam kurun waktu 10 tahun, 2) PDF Ulya Al Fithrah telah berhasil meluluskan santri dan berhasil mendaftar ke Perguruan Tinggi terutama di UIN, 3). PDF Ulya Al Fithrah memiliki legitimasi yang kuat dari Pemerintah dan telah memiliki Nomor Pokok Sekolah Nasional (NPSN) 69937227 dan NSPDF 231235780008, 4) PDF Al Fithrah merupakan PDF yang berada di bawah pondok pesantren salafiyah murni yang kental sekali dengan tariqat Nasyabandiyah Qadiriyah Ustsmaniyah, dan 5) Ponpes Al Fithrah terkenal dengan adaptifitas terhadap perkembangan lembaga pendidikan dan selalu mengikuti regulasi dari Pemerintah.

Desain penelitian dirumuskan dengan desain penelitian kualitatif. Oleh karena itu, pengumpulan data dilakukan dengan teknik wawancara, pengamatan, telaah dokumen dan Focus Group Discussion (FGD). Wawancara dilakukan dengan Kepala PDF Ulya Al Fithrah sebagai informan utama, Waka. Kurikulum santri PDF Ulya Al Fithrah, Ka. TU PDF Ulya, orang tua santri, dan santri PDF Ulya. Pengamatan dilakukan pada 
saat pembelajaran di kelas dan di masjid, pada saat santri istirahat, dan pada saat santri mengikuti kegiatan pondok seperti tawajuhan, istighotsah, dan manaqiban baik di siang hari maupun di malam hari. Telaah dokumen dilakukan untuk memperoleh data-data yang bersifat dokumenter, seperti kitab/buku sebagai bahan ajar, profil pondok pesantren, dan berbagai dokumen yang bersifat foto kegiatan PDF Ulya. Focus Group Discussion (FGD) dilakukan sebagai langkah triangulasi data terhadap hasil temuan sementara yang masih memerlukan penjelasan lebih komprehensif. Dalam FGD ini dilibatkan peserta dari Pondok pesantren salafiyah lain yang memiliki potensi untuk menyelenggarakan PDF.

Di samping data primer seperti yang dijelaskan di atas juga dilakukan pengumpulan data yang bersifat data sekunder. Data sekunder ini dihasilkan dari hasil pengamatan interaksi antara santri dengan santri, santri dengan pengasuh, pengamatan di kelas pada saat pembelajaran berlangsung baik pembelajaran kitab kuning maupun mata pelajaran umum, pengamatan pada saat kegiatan ekstrakurikuler santri, dan sumber data yang dihasilkan dari telaah jargon-jargon yang tertera di dinding Ppondok pesantren.

Analisis dalam penelitian ini menekankan pada analisis konteks terkait dengan penyelenggaraan PDF Ulya Al Fithrah dan proses pembelajaran yang meliputi kurikulum atau bahan ajar yang terkait dengan pembentukan kader ulama. Adapun konteks dilihat dari seluruh rangkaian proses dari 
input, raw input, process, dan out put. Dari proses analisis inilah, penelitian ini menekankan pada analisis secara siklik, yaitu sejak mulai dilakukan proses pengumpulan data, penyajian data, reduksi data, dan penarikan kesimpulan. Secara skematis analisis tersebut sebagaimana yang dikembangkan oleh Mills \& Hubbermen (1984), yaitu

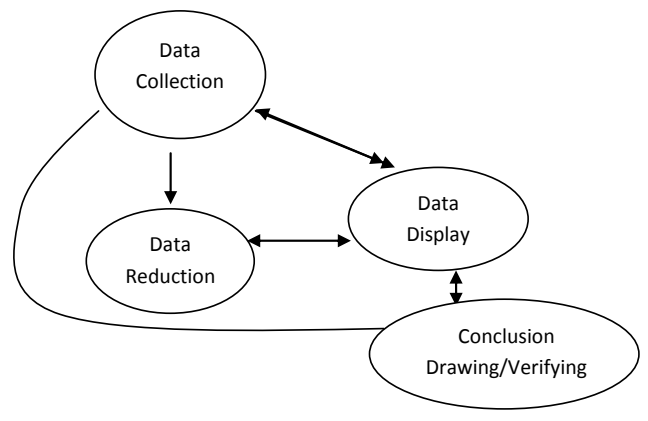

Alur analisis model siklik dari Mills \& Hubbermen di atas bahwa penelitian ini dilakukan dengan pengumpulan data sebagai langkah awal kemudian dilakukan reduksi data untuk pemilahan data, dan penyederhanaan data dari catatan lapangan. Semua data yang dikumpulan dan dianalisis adalah data yang sesuai dengan pokok masalah yang telah ditetapkan sebagai tujuan penelitian. Dalam analisis ini diperkuat dengan hasil triangulasi data melalui FGD Metode ini digunakan untuk cross check data sekaligus untuk memperoleh kebenaran informasi yang diperoleh sebelumnya berdasarkan hasil wawancara Menurut Moleong (2008), bahwa dengan triangulasi data tersebut peneliti dapat me-recheck temuanya dengan jalan membandingkannya dengan berbagai sumber, metode, atau teori. 


\section{Bab III}

\section{PENDIDIKAN DINIYAH FORMAL (PDF) ULYA AL FIHTRAH; PENCETAK KADER ULAMA TOLERAN}

Pondok Pesantren Al Fithrah berada di jalan Kedinding Lor nomor 99 Kedinding Kenjeran Surabaya. Pondok Pesantren Assalafi Al Fithrah didirikan tahun 1985 oleh Hadhratusy Syaikh KH. Achmad Asrori Al Ishaqy RA (Kyai Asrori) putera dari Kyai Utsman Al-Ishaqi ${ }^{1}$ (meninggal tahun

${ }^{1}$ Kyai Utsman Al-Ishaqi adalah mursyid Tarekat Qadiriyah wa Naqsyabandiyah. dan sepeninggal Kiai Utsman tahun 1984 diteruskan oleh putranya Kiai Ahmad Asrori sebagai mursyid. Dari sinilah ketokohan Kiai Asrori mulai nampak meskipun masih dalam usia yang masih muda. Langkah menjadi mursid di usia muda ini ternyata ada sebagaimana diceritakan pada tanggal 16 Maret 1988 beberapa pengikut berangkat meninggalkan Surabaya menuju Kebumen untuk melakukan baiat kepada Kiai Sonhaji. Langkah tersebut tidak menyurutkan langkah Kiai Asrori menjadi mursid sekaligus memimpin pesantren Al-Fithrah di Kedinding Lor dengan sistem klasikal dan kurikulum yang diterapkan menggabungkan pengetahuan umum dan pengajian kitab kuning. Langkah lain 
1984). Proses pendirian tidak berbeda dengan pondok pesantren besar lainnya seperti Ponpes Tebuireng, yaitu bermula dari kediaman Kyai Asrori dan mushola. Adapun santri tidak hanya yang mondok di Ponpes tersebut melainkan terdapat santri yang berasal dari Pondok Pesantren Darul 'Ubudiyah Jatipurwo Surabaya yang didirikan dan diasuh oleh Hadhrotusy Syaikh Al Arif Billah KH. Muhammad Utsman Al Ishaqy ra.

dari Kyai Ahmad Asrori adalah menggagas jamaah Al-Khidmah yang sebagian anggotanya adalah pengamal tarekat Tarekat Qadiriyah wa Naqsyabandiyah. Jamaah ini menarik karena sifatnya yang inklusif tidak memihak salah satu organisasi sosial manapun dan murni keagamaan tanpa muatan-muatan politis, terbuka bagi siapa saja yang ingin menempuh perjalanan mendekat kepada Tuhan tanpa membedakan baju dan kulit luarnya. Riawayat belajar Kiai Asrori tidak teratur, yaitu belajar di Rejoso satu tahun, di Pare satu tahun, dan di Bendo satu tahun. Di Rejoso ia malah tidak aktif mengikuti kegiatan ngaji. Ketika hal itu dilaporkan kepada pimpinan pondok, Kiai Mustain Romli, ia seperti memaklumi, "biarkan saja, anak macan akhirnya jadi macan juga." Meskipun belajarnya tidak tertib, yang sangat mengherankan, Kiai Asrori mampu membaca dan mengajarkan kitab Ihya' Ulum al-Din karya AlGhazali dengan baik. Silsilah Kyai Asrori adalah Kyai Ahmad Asrori Al Ishaqi - Muhammad Utsman - Surati - Abdullah - Mbah Deso - Mbah Jarangan - Ki Ageng Mas - Ki Panembahan Bagus - Ki Ageng Pangeran Sedeng Rana - Panembahan Agung Sido Mergi - Pangeran Kawis Guo Fadlullah Sido Sunan Prapen - Ali Sumodiro - Muhammad Ainul Yaqin Sunan Giri - Maulana Ishaq - Ibrahim Al Akbar - Ali Nurul Alam - Barokat Zainul Alam - Jamaluddin Al Akbar Al Husain - Ahmad Syah Jalalul Amri Abdullah Khan - Abdul Malik - Alawi - Muhammad Shohib Mirbath Ali Kholi' Qasam - Alawi - Muhammad - Alawi - Ubaidillah - Ahmad Al Muhajir - Isa An Naqib Ar Rumi - Muhammad An Naqib - Ali Al Uraidli Ja'far As Shodiq - Muhammad Al Baqir - Ali Zainal Abidin - Hussain Bin Ali - Ali Bin Abi Thalib / Fathimah Binti Rasulullah SAW. (disarikan dari laman Website pribadi Muhammad Ismi Musyafani https://www. alfithrah99sby.org. 15 Februari 2010.). 
Perkembangan pondok pesantren mulai nampak ketika pada tahun 1990 kedatangan beberapa santri dengan kegiatan 'ubudiyah dan mengaji secara sorogan dan bandongan di mushola. Jumlah santri pada saat itu masih sedikit sehingga belum secara formal dijadikan sebagai pondok pesantren. Setelah terjadi penambahan santri yang cukup banyak (25 santri) maka pada tahun 1994 Kyai Achmad Asrori Al Ishaqy memutuskan untuk mendirikan Pondok Pesantren dan mengatur pendidikan secara klasikal. Konsekuensi dari sistem klasikal inilah menambah ketertarikan masyarakat dan meminta untuk menerima santri putri. Pada tahun 2003 Pondok pesantren Al Fithrah membuka pendaftaran santri putri dan pada awal pembukaan diterima 77 santri putri. (https://www. alfithrah99sby. org dan wawancara dengan pengurus PDF Ulya Al Fithrah dalam FGD).

Sistem klasikal yang diselenggarakan Ponpes Al Fithrah lambat laun menginspirasi para santri untuk mengikuti model pendidikan formal lanjutan. Para santri yang berjumlah lebih dari 3000 santri (98\% mukim) lebih banyak menginginkan studi lanjutan ke jenjang yang lebih tinggi setelah keluar dari pondok pesantren. Keinginan tersebut diakomodasi dengan menyelenggarakan program Paket $\mathrm{C}$ setingkat sekolah lanjutan menengah (SMA). Program ini berjalan tidak lama karena Kementerian Agama mengeluarkan SK Dirjen Pendidikan Islam No. : DJ I/457/2008 tanggal 23 Desember 2008. Dalam SK Dirjen tersebut 
pendidikan setingkat Madrasah Aliyah dapat dilakukan dengan sistem Mu'addalah. Program ini mendapat respons dari Ponpes Al Fithrah dan mendapat sambutan dari para santri. Respons pengelola Ponpes Al Fithrah merupakan respons positif yang selalu mengikuti perkembangan dan regulasi Pemerintah dalam regulasi penyelenggaraan pendidikan. Di samping itu, kebutuhan santri untuk melanjutkan ke Perguruan Tinggi Islam seperti IAIN/UIN maupun perguruan tinggi Islam Swasta dan Ma'had 'Aly cukup tinggi.

Inklusivitas Ponpes Al Fithrah dalam mengikuti perkembangan pendidikan nasional sangat terbuka dan adapatif dengan regulasi yang dikeluarkan oleh Pemerintah. Kemudahan menerima hal yang baru dalam dunia pondok pesantren salafiyah biasanya cukup alot, akan tetapi yang dilakukan oleh Kyai Ahmad Asrori menjadikan ponpes ini mengalami dinamika yang signifikan dan mendapat respon positif dari masyarakat². Bahkan anak-anak di wilayah Kenjeran cukup banyak yang menjadi santri kalong atau santri yang dilaju dari rumah untuk mengikuti pembelajaran di pondok pesantren.

Jargon Al Mukhaafadlotu 'alalqadiimisshalih wal akhdzu bil jadidiil ashlakh bagi Ponpes Assalafi Al Fithrah menjadi

${ }^{2}$ Ketenaran Ponpes Al Fithrah sama dengan ketenaran nama Kyai Ahmad Asrori dengan sebutan Pondok Pesantren "Abah Asrori, Yai Asror, Kyai Asrori" sebagai sebutan yang familiar dan terkesan sudah menjadi bagian dari masyarakat. 
jargon yang benar-benar untuk diaplikasikan dalam model penyelenggaraan pendidikan. Hanya saja ada program yang tidak dapat ditawar-tawar. Menurut Hermansyah (Waka Kurikulum PDF 'Ulya) terdapat program yang "mabni” yang tidak boleh ada perubahan maupun pergeseran. Program tersebut merupakan program yang di desain oleh pendiri Kyai Ahmad Asrori sampai kapanpun. Program selain Syi'ar yang biasa dilakukan pada minggu awal dengan manaqib, pengajian ahad pagi pada ahad kedua, haul, majlis dzikir, dan maulidur Rasul adalah program yang dikenal dengan istilah Wadlifah.

Program Wadlifah adalah kegiatan yang berkaitan langsung dengan Allah Swt., Rasulullah Muhammad SAW, Syaikh Abdul Qadir Al Jailani, dan Syaikh KH. Achmad Asrori Al Ishaqy. Kegiatan ini berguna untuk menanamkan dan melatih tanggungjawab dan kejujuran hati kepada Allah Swt. Adapun jenis kegiatan yang yang tidak boleh diubah oleh siapapun dan kapanpun meliputi:

1. Jama'ah Maktubah, shalat sunnah (Qabliyah dan ba'diyah, Isyraq, Dhuha, Isti'adah, Tsubutil Iman, Hajat, dan Tasbih)

2. Aurod-aurod yang telah dituntunkan dan dibimbingkan

3. Qiro'atul Qur'an al Kariim setelah tahlil shubuh diawali dengan membaca al Faatihah 3 kali. Dalam membaca Al Qur'an ini dilakukan dengan sendirisendiri satu juz dan ditutup dengan kalamun dan do'a Al Qur'an 
4. Maulid setiap malam jum'at diawali dengan membaca Al Fatihah 3 kali kemudian membaca Ya Robbi Inna Fatahna Yaa Rasulullah. Dalam membaca ini dipandung oleh pembaca. Setelah bacaan selesai dilanjutkan dengan membaca Rowi mulai dari Alhamdulillah Al Qowiyyu Al Gholib secara sendirisendiri sampai Fahtazzal 'Arsyu dilanjutkan dengan Mahallul Qiyaam yang dikomandoni oleh pembaca. Setelah bacaan ini selesai dilanjutkan dengan Wawulida dan Rowi-rowi secara mandiri sampai selesai dengan do'a. Setelah acara ini selesai dilanjutkan dengan membaca Nasyid yang diiringi dengan nasyid.

Berbagai program dan kegiatan yang diselenggarakan Ponpes Assalafi Al Fithrah di atas merupakan perwujudan dari visi ponpes yaitu mensuritauladani akhlaqul karimah baginda habibillah Rasulillah Muhammad saw., meneruskan perjuangan salafush sholih, terdepan dalam berilmu dan beragama serta mampu menghadapi tantangan zaman. Program dan kegatan juga merupakan penerapan dari misi ponpes yaitu;

1. Membentuk jiwa santri yang mampu Mensuritauladani Akhlaqul Karimah Baginda Habibillah Rasulillah Muhammad SAW.

2. Membentuk santri yang mampu melanjutkan perjuangan Salafusholih sebagai mana dicontohkan baginda Habibillah Rosululloh SAW. 
3. Membentuk santri yang Terdepan dalam berilmu dan beragama

4. Membentuk santri yang Mampu menghadapi tantangan zaman.

Dalam obrolan dengan pengelola PDF 'Ulya bahwa penyelenggaraan ponpes Al Fithrah dengan berbagai kegiatan menjadi sebuah jaminan para santri apabila keluar atau selesai belajar di Ponpes Assalafi ini diperoleh jaminan kelulusan. Adapun jaminan kelulusan tersebut adalah 1) memiliki kesadaran beribadah, 2) mampu membaca $\mathrm{Al}$ Qur'an dengan tartil, 3) hafal Aurad yang telah dituntunkan, 4) memiliki sikap jujur, disiplin, santun serta berbudaya bersih dan sehat, 4) mampu membaca dan memahami kutub at turrats, 5) terbiasa melaksanakan kegiatan sosial keagamaan, 6) lulus ujian Madrasah dan UAN, dan 7) memiliki keterampilan hidup.

Perkembangan ponpes Assalafi Al Fithrah semakin berkembang terutama dalam mengembangkan lembaga pendidikan formal, non formal dan lembaga pendidikan khusus. Menurut Achmad Kunawi ada 5 hal yang menjadikan Ponpes Al Fithrah semakin berkembang pesat meskipun pendirinya KH. Achmad Asrory Al Ishaqy telah meninggal dunia dan pengelolaan pondok maupun lembaga diserahkan bukan pada anak dan keluarganya melainkan pada jamaah. Kelima hal tersebut menjadi kekuatan yang fundamental dan telah tersistem yang dibangun oleh Kiai Achmad Asrory Al 
Ishaqy itu sendiri. Bahkan dalam tataran "elit" pengelola kelima hal tersebut dikenal dengan 5 pilar, yaitu

1. Thariqat Naqsyandiyah Qadiriyah Utsmaniyah. Thariqat ini merupakan thariqat peninggalan $\mathrm{KH}$. Achmad Asrory Al Ishaqy sebagai pewaris dari ayahnya atau Bertalqin dan berbai'at dari ayahnya $\mathrm{Al}$ Arif Billaah Hadrotusy-syaikh Muhammad 'Utsman bin Nadiy Al Ishaqi. Ayah KH. Achmad Asrory Al Sihaqy bertalqin dan berbai'at dari Al Arif Billaah Hadrotusy-syaikh Abi Ishamuddiyn Muhammad Romliy At Tamimimiy. Sejarah thariqat ini cukup panjang sampai ayah KH. Meninggal dunia mengangkat mursid KH. Achmad Asrory Al Ishaqy yang pada saat itu masih terlalu muda (usia 30 tahun). Akibat dari pengangkatan ini beberapa muridnya sempat keluar untuk berpindah ke thariat yang lain. Pada saat KH. Achmad Asrory meninggal dunia tidak mengangkat mursid sehingga ketokohan thariqat bersifat kolektif kolegial. ${ }^{3}$

${ }^{3}$ Menurut Achmad Kunawi (Kepala PDF Ulya Al Fithrah), sebelum KH. Achmad Asrori Al Ishaqy meninggal dunia telah memberikan sinyal, yaitu ketika memimpin jamiahan di masjid selalu ijin karena kondisi fisik yang lagi sakit dan menunjuk diantara jamaah thariqat untuk memimpin menggantikan dirinya. Pada setiap permintaan penggantian imam selalu berganti-ganti yang diminta sehingga para tokoh thariqat merasa diangkat derajatnya. Kegiatan seperti ini terus terjadi sampai pada akhirnya KH. Ahmad Asrory Al Ishaqy meninggal dunia tidak menunjuk satu muridpun yang menjadi mursid. Disinilah Thariqat Naqsyabandiyah Qadiriyah Usmaniyah menjadi sangat populer dan semakin bertambah jamaahnya karena dipimpin berdasarkan koletif kolegial. 
2. Perkumpulan Jamaah Al Hikmah. Perkumpulan jamaah ini aktif mengadakan kegiatan istghotsah maupun kegiatan lain setiap hari minggu dan diikuti dari berbagai daerah sekitar. Bahkan pada saat penelitian ini dilakukan terdapat rombongan jamaah dari Pedurungan Semarang. Dalam perkumpulan jamaah AL Hikmah ini juga dipimpin oleh jamaah yang berasal bukan dari keluarga "Ndalem" Kiai, sehingga aktifitasnya tidak tergantung pada satu figur melainkan pada banyak figur yang terus menrus akan tumbuh figur baru.

3. Pondok Pesantren Assalafi Al Fithrah. Pondok ini merupakan cikal bakal dari semua penyelenggaraan kegiatan yang ada di ponpes. Pengelola ponpes Al Fithrah juga bukan dari keluarga pendiri sehingga proses pergantian dilakukan dengan musyawarah secara profesional dan kompeten. Model penggantian kepemimpinan ketua ponpes ini dilakukan dengan melibatkan seluruh komponen pengelola ponpes dan hanya memimipin maksimal 2 periode. Hasil dari musyawarah disampaikan pada keluarga "Ndalem" baik $\mathrm{Bu}$ Nyai maupun keluarga dari putra dan putrinya untuk mendapatkan persetujuan lisan. Selama ini apabila pergantian kepemimpinan hasil musyawarah tidak pernah mendapat penolakan dari keluarga "Ndalem" sehingga tingkat kepercayaan diri ketua ponpes sangat tinggi. Begitu juga dari program yang dikembangkan oleh pengelola pondok selalu mendapat "restu" dari keluarga "Ndalem" sehingga tidak ada hambatan. 
4. Yayasan Al Hikmah Indonesia. Yayasan ini memiliki cabang di beberapa daerah di Jawa Timur dan di Jawa Tengah. Yayasan AL Hikmah yang menanugi semua kegiatan pondok pesantren dan lembaga pendidikan yang dikembangkan berfungsi hanya sebagai penyedia sarana dan prasarana. Oleh karena itu itu semua lembaga pendidikan yang ada apabila membutuhkan sarana prasarana melaporkan pada Yayasan, hal ini dikarenakan semua sistem keuangan berada di bendahara Yayasan yang tidak diintervensi oleh siapapun sekalipun keluarga "Ndalem". Status Yayasan berbadan hukum adalah independen dimana dalam pengelolaan dilakukan oleh ketua yang dipilih secara musyawarah mufakat. Kedudukan keluarga "Ndalem" hanya sebagai penasehat dan tidak melakukan intervensi ke dalam. Pengurus Yayasan memiliki kekuasan "penuh" untuk memberikan advice kepada stake holder yang ada dibawahnya.

5. Keluarga Ndalem, yaitu keluarga KH. Achmad Asrori Al Ishaqy sebagai pendiri menjadi sangat penting kedudukannya. Meskipun keluarga Ndalem ini tidak terlibat langsung dalam pengelolaan berbagai kegiatan ponpes Al Fithrah, akan tetapi kedudukannya di atas semua lembaga yang ada. Secara struktural keluarga Ndalem tidak termasuk dalam seluruh organisasi yang ada di pondok pesantren, akan tetapi secara kultural memiliki pengaruh yang sangat besar. Hal ini sangat disadari oleh seluruh komponen dari Yayasan sampai pada organisasi terkecil di lingkungan Pondok pesantren. Hal ini 
sangat wajar karena pondok pesantren merupakan pondok yang didirikan oleh keluarga Ndalem (keluarga Syaikh KH Achmad Asrory Al Sihaqy) sehingga sampai kapanpun akan menjadi bagian utama dari seluruh komponen proses penyelenggaraan pondok pesantren Al Fithrah.

Tidak terlibatnya keluarga Ndalem KH. Achmad Asrory Al Ishaqy dalam struktur kepengurusan semua organisasi menurut Achmad Kunawi benar-benar menunjukan bahwa Ponpes ini dikelola secara profesional. Kompetensi dan soliditas pengurus pada semua lini organisasi menjadi sangat diperhatikan. Sebagai salah satu contoh, ketika Achmad Kunawi menjadi Kepala MI Al fithrah dengan santri yang sangat sedikit mengadakan terobosan, yaitu diformalkan (dijadikan lembaga pendidikan formal) maka pada awalnya mendapat respon kurang setuju dari keluarga Ndalem karena khawatir pendidikan agamanya menjadi hilang atau berkurang. Akan tetapi melihat kondisi MI yang tidak diminati oleh masyarakat dan pengelola/pengurus organisasi intra ponpes, Achmad Kunawi meyakinkan dengan menyampaikan berbagai rpogram yang strategis sehingga pendidikan keagamaan tetap berjalan sesuai dengan karakter pondok pesantren.

Perjuangan Achmad Kunawi ternyata membuahkan hasil yaitu pada tahun 2012 menjadi lembaga pendidikan formal. Keberhasilan MI menjadi lembaga pendidikan formal ini langsung disosialisakan oleh seluruh komponen pondok 
pesantren pada masyarakat sekitar yang memiliki tingkat relegiusitas tinggi. Hasil sosialisasi ternyata tidak terduga, pada tahun berikutnya yang mendaftar menjadi santri di MI sangat banyak, yaitu mencapai puluhan santri dan sekarang setiap tahun menerima lebih dari 100 santri. Gambaran seperti inilah menunjukan bahwa kompetensi, profesionalitas, dan kepercayaan tidak harus dari keluarga pendiri ponpes, melainkan dari berbagai komponen yang memiliki integritas tinggi dalam membangun pondok pesantren. Dari keberhasilan inilah, Achmad Kunawi diberi tugas untuk menyelenggarakan Pendidikan Diniyah Formal (PDF) Ulya Al Fithrah untuk periode awal. Ada hal yang selalu diingat dari almarhum KH Achmad Asrory Al Ishaqy sebelum meninggal, yaitu "Jangan menggantungkan saya, akan tetapi bertindaklah profesional meskipun keputusan penting yang harus dikonsultasikan".

\section{口 TANTANGAN PONDOK PESANTREN ASSALAFI AL FITHRAH MENGHADAPI ERA LEMBAGA PEN- DIDIKAN FORMAL 4}

Perjalanan Ponpes Assalafi Al Fithrah dalam mengikuti model penyelenggaraan lembaga pendidikan formal tidak mengalami kesulitan. Hal ini dikarenakan ponpes sejak awal

${ }^{4}$ Data yang dideskripsikan dalam kaporan dibawah ini didasarkan pada hasil wawancara dengan pengelola PDF Al Fithrah dan dokumen yang berjudul "Buku Profil Pendidikan Diniyah Formal (PDF) Ulya Al Fithrah Surabaya" Pondok Pesantren Assalafi AL Fithrah Surabaya Kedinding Lor 99, Surabaya. 
memiliki kepedulian terhadap santri yang menginginkan pendidikan yang bisa untuk studi lanjut dan para santri juga mlenginginkan adanya lembaga pendidikan formal yang mampu menghantarkan studi lanjut. Ponpes Assalafi Al Fithrah selalu merespon keinginan santri dan mengikuti regulasi yang ditetapkan oleh Pemerintah (Kementerian Agama). Menurut Hermansyah bahwa Ponpes ini selalu mengikuti regulasi Pemerintah dalam penyelenggaraan pendidikan formal akan tetapi tetap mempertahankan tradisi kitab kuning sebagai kurikulum pokok. Bahkan menurut Achmad Kunawi, M.Pd (Kepala PDF 'Ulya) kurikulum yang diterapkan $70 \%$ sampai $75 \%$ Pendidikan Agama (bersumber pada kitab-kitab kuning) dan $30 \%$ atau $25 \%$ kurikulum yang bersifat umum.

Diantara regulasi Pemerintah yang diterapkan oleh Ponpes Assalafi Al Fithrah adalah model Paket C. Penyelenggaraan Paket $\mathrm{C}$ ini setingkat dengan SMA sehingga para santri setelah mengikuti ujian Paket $\mathrm{C}$ dapat melanjutkan ke Perguruan Tinggi. Program Paket C ini menjadi tambah menarik setelah Menteri Kelautan (Susi Pujiastuti) mengikuti ujian Paket C melalui Ujian Nasional Berbasis Komputer (UNBK) di SMA Negeri 1 Pangandaran selama tiga hari pada 11 Mei hingga 13 Mei 2018 dan lulus terbaik dari 550 peserta.

Pada tahun 2008 dengan keluarnya SK Dirjen Pendidikan Islam No. DJ I / 457 / 2008 tanggal 23 Desember 2008, Ponpes menyelenggarakan program Mu'addalah 
sebagai pendidikan setingkat dengan Madrasah Aliyah/SMA. Program ini diselenggarakan dan berjalan dengan baik. Namun demikian seiring dengan munculnya regulasi baru yaitu diterbitkanya PMA (Peraturan Menteri Agama) No. 13 tahun 2014 tentang Pendidikan Keagamaan Islam membuka layanan Pendidikan Diniyah Formal (PDF). Ketertarikan untuk menyelenggarakan PDF ini adalah karena PDF merupakan salah satu dari entitas pendidikan keagamaan Islam yang bersifat formal untuk menghasilkan lulusan mutafaqqih fiddin (ahli ilmu agama Islam) guna menjawab atas langkanya kader mutafaqqih fiddin dan berbasis pada kitab kuning (kutub al-turats), sedangkan mata pelajaran umum hanya terdiri atas Pendidikan Kewarganegaraan, Bahasa Indonesia, Matematika, dan Ilmu Pengetahuan Alam (buku Profil, 1438: 1).

Ada dua alasan Ponpes Assalafi Al Fithrah menyelenggarakan PDF 'Ulya dan pada tanggal 20 Mei 2015 menjadi salah satu dari 14 Ponpes pertama yang mendapat pengakuan dari Kemenag RI sebagai penyelenggara PDF dengan piagam nomor 2915 tahun 2015 dengan nomor statistik 231235780008. Kedua alasan tersebut adalah berangkat dari dawuh KH. Achmad Asrori Al Ishaqy dan PMA Nomor 13 tahun 2014 sejalan dengan pemikiran Syaikh KH. Achmad Asrori Al Ishaqy (buku profil, 1438: 2).

Visi PDF 'Ulya Al Fithrah adalah Membentuk santri berakhlakul karimah, berilmu, dan berprestasi tingkat 
nasional 2021. Indikator pencapaian visi tersebut dilakukan langkah-langkah sebagai berikut,

1. Berakhlakul Karimah

a. Memiliki sikap sopan santun, jujur, disiplin, serta berbudaya hidup bersih dan sehat

b. Memiliki sikap toleransi dan solidaritas

c. Mengamalkan tuntunan Hadratusy Syaikh K.H. Achmad Asrory Al Ishaqy

2. Berilmu

a. Mampu membaca al Qur'an dengan baik dan benar

b. Mampu menghafal juz 1 dan 30 serta surat al ma'tsurat

c. Memahami makna al Qur'an

d. Hafal aurad yang telah dituntunkan Hadratusy Syaikh K.H. Achmad Asrory Al Ishaqy

e. Mampu membaca dan memahami kutub al turats (Fiqhul manhaji / Kifayatul akhyar, dan Fathul Muin)

f. Lulus ujian ahir berstandar nasional PDF 'Ulya rata-rata nilai 75

g. Memiliki keterampilan hidup (Berbahasa Inggris, Arab, dan Komputer)

3. Berprestasi

a. Berprestasi dalam lomba baca kitab kuning tingkat nasional

b. Berprestasi dalam lomba pidato, story teling, dan olimpiade nahwu shorof tingkat provinsi

c. Masuk Ma'had 'Aly dan Perguruan Tinggi Islam Negeri 
Dari visi dan capaian visi PDF Al Fithrah tersebut merupakan konsep ideal untuk mencapai tujuan penyelenggaraan PDF dan santri keluar dari ponpes memiliki karakter sesuai dengan visi tersebut. Di antara karakter yang dibangun melalui visi tersebut adalah berakhlak mulia. Karakter ini seperti memiliki sikap sopan santun, jujur, disiplin, serta berbudaya hidup bersih dan sehat, dan memiliki sikap toleransi dan solidaritas. Visi ini ditegaskan dalam misi yang dilakukan yaitu menyelenggarakan pendidikan diniyah menengah yang bermutu untuk membentuk jiwa santri yang mensuritauladani Akhlak Rasulullah SAW., melanjutkan perjuangan ulama salafushsholih yang berilmu dan beramaliah serta mampu menghadapi tantangan zaman. Visi tersebut juga termotivasi dengan motto yang dipasang di bagian terdepan madrasah seperti dibawah ini;

\section{TERDEPAN DALAM IPTEK \& AGAMA}

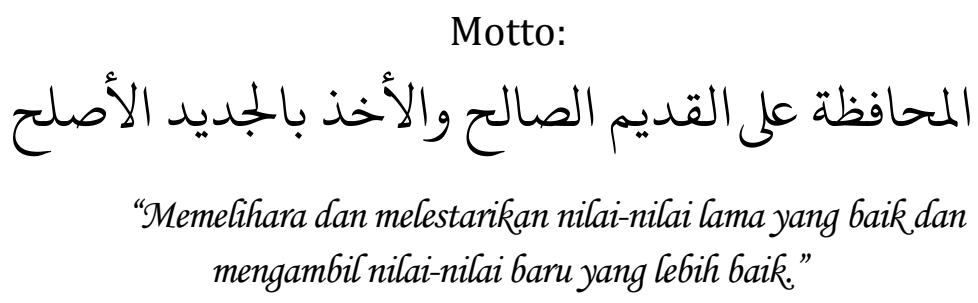

Jaminan mutu yang menjadi misi dan kualitas santri setelah mengalami proses pembelajaran di PDF 'Ulya Al Fithrah adalah sebagai berikut; 1) Hafidz juz 1 dan 30 serta beberapa surat al ma'tsurat, 2) hafal aurad yang telah dituntunkan oleh Hadratusy Syaikh K.H. Achmad Asrory Al 
Ishaqy, 3) mampu membaca dan memahami kitab at turats (kifayatul akhyar atau manhaji), dan 4) lulusan diterima di Perguruan Tinggi, baik swasta maupun negeri.

Dari visi dan misi di atas, PDF Al Fithrah telah menyusun Road Map arah dan target pengembangan. Road Map tersebut berdasarkan analisis lingkungan PDF dan memungkinkan PDF PDF melakukan pengembangan dan pembenahan secara bertahap. Secara umum pembenahan dan pengembangan dilakukan melalui tahapan berikut.

\begin{tabular}{|c|c|c|c|}
\hline \multicolumn{4}{|c|}{ ROAD MAP PENGEMBANGAN PDF } \\
\hline $\begin{array}{l}\text { TAHAP } 1 \\
\text { Pendidikan } \\
\text { Diniyah yang } \\
\text { standar } 2017 \\
\text {-2018 }\end{array}$ & $\begin{array}{l}\text { TAHAP } 2 \\
\text { Pendidikan Diniyah } \\
\text { yang unggul 2018- } \\
2019\end{array}$ & $\begin{array}{l}\text { TAHAP } 3 \\
\text { Pendidikan } \\
\text { Diniyah yang } \\
\text { berprestasi } \\
\text { 2019-2020 }\end{array}$ & $\begin{array}{l}\text { TAHAP } 4 \\
\text { Pendidikan } \\
\text { Model } 2020 \\
2021\end{array}$ \\
\hline $\begin{array}{l}\text { TARGET } \\
\text { Pembiasaan } \\
\text { karakter } \\
\text { berjalan } \\
\text { Kurikulum } \\
\text { tersusun } \\
\text { Pembelajara } \\
\text { n berjalan } \\
\text { secara baik }\end{array}$ & $\begin{array}{l}\text { TARGET } \\
\text { Pembiasaan karakter } \\
\text { telah berjalan } \\
\text { Kurikulum tersusun } \\
\text { secara ideal } \\
\text { Pembelajaran } \\
\text { berjalan secara baik } \\
\text { dan kontekstual }\end{array}$ & \begin{tabular}{|l} 
TARGET \\
- Karakter \\
sudah \\
menjadi \\
budaya bagi \\
santri PDF \\
'Ulya \\
- Unggul \\
dalam \\
akademik \\
dan non \\
akademik
\end{tabular} & $\begin{array}{l}\text { TARGET } \\
\text { Menjadi model } \\
\text { bagi PDF yang } \\
\text { lain dalam } \\
\text { pembiasaan } \\
\text { maupun dalam } \\
\text { kurikulum dan } \\
\text { pembelajaran }\end{array}$ \\
\hline
\end{tabular}

Dengan adanya road map yang telah disusun, maka jaminan mutu PDF 'Ulya merupakan tantangan tersendiri untuk dapat dicapai setelah santri menyelesaikan studi selama 3 tahun. Jaminan mutu ini bukan sekedar menjadi tantangan pondok pesantren dalam mencetak santri yang 
memiliki penguasaan kitab kuning karya ulama salaf melainkan juga menjadi tantangan tersendiri dalam penyelenggaraan PDF sebagai lembaga pendidikan formal. Kualitas PDF 'Ulya Fithrah menjadi barometer dalam menghadapi persaingan di era kuatnya penyelenggaraan lembaga pendidikan formal. Paling tidak ada 3 hal yang menjadi tantangan tersendiri secara umum Ponpes $\mathrm{Al}$ Fithrah menyelenggarakan PDF 'Ulya di era gencarnya penyelenggaraan lembaga pendidikan formal. Tantangan tersebut adalah;

1. Ponpes Assalafi Al Fithrah merupakan Ponpes pertama yang menyelenggarakan Pendidikan Diniyah Formal (PDF) di wilayah Kota Surabaya dan salah satu dari 14 PDF yang ada di Indonesia sehingga memiliki tanggungjawab harus memiliki kualitas yang baik dan lulusanya dapat melanjutkan ke Perguruan Tinggi Negeri minimal Swasta.

2. Sebagai Ponpes pertama yang menyelenggarakan PDF, maka akan menjadi pilot projek atau percontohan bagi ponpes lainnya yang akan menyelenggarakan PDF. Dengan demikian PDF Al Fithrah harus siap menjadi pusat konsultasi bagi ponpes lain yang akan mendirikan PDF

3. Mengingat orientasi PDF 'Ulya Al Fithrah adalah menyiapkan santri untuk melanjutkan ke Perguruan Tinggi, maka harus menyiapkan lulusan mampu bersaing dengan lulusan Madrasah Aliyah bahkan dengan sekolah menengah umum yang sudah lebih lengkap dari SDM dan fasilitas pembelajaran. 
Selain tantangan secara umum, terdapat tantangan internal dalam proses pembelajaran di kelas. Tantangan pembelajaran PDF Al Fithrah sebagai lembaga pendidikan formal dapat dilihat dalam beberapa aspek, yaitu

1. Input santri yang mendaftar menjadi santri PDF berasal bukan saja dari Ponpes Al Fithrah, melainkan dari berbagai ponpes lain di sekitar Surabaya maupun di luar Surabaya. Kondisi ini mengharuskan piha penyelenggara mengadakan kegiatan isti'dadiyah selama 1 tahun sebagai program persiapan agar santri memiliki kemampuan yang standar untuk mengikuti pemelajaran di kelas.

2. SDM tenaga pendidik perlu dipersiapkan untuk menjaga kompetensi dan profesionalitas. Sementara ini masih terdapat guru yang missmatch dimana guru lulusan S.1 dengan jurusan Tafsir/Hadits akan tetapi mengajar matematika ${ }^{5}$.

${ }^{5}$ Secara akademis, tenaga pendidik memiliki latarbelakang pendidikan S.1 dan S.2. Namun demikian, pada tataran praktis tidak semua guru mengajar atau memegang mata pelajaran sesuai dengan ijazah atau kompetensi yang dimiliki. Sebagai salah satu contoh adalah lulusan S.1 dari jurusan Tafsir/Hadis mengajar mata pelajaran matematika. Meskipun secara keilmuan mumpuni, hal ini dapat dibuktikan dengan lulusan PDF Al Fithrah angkatan 1 tahun 2018 yang diterima di Perguruan Tinggi Negeri dengan jurusan Matematika. Sekedar informasi bahwa pada tahun pelajaran 2017/2018 PDF Al Fithrah telah meluluskan santri angkatan 1 dengan jumlah 225 santri. Dari jumlah tersebut diterima di berbagai Perguruan Tinggi, seperti di UIN Malang, Universitas Negeri Malang, Universitas Trunojoyo, dan mayoritas diterima di Ma'had 'Aly. Khusus yang diterima di Ma'had 'Aly di lingkungan Ponpes Assalafi Al Fithrah dengan konsentrasi tasawuf dan thariqah yaitu Ma'had 'Aly Alfithrah bekerjasama dengan STAI Al Fithrah prodi Akhlak dan 
3. Fasilitas pembelajaran terutama untuk mata pelaharan umum yang belum terpenuhi sehingga oembelajaran mengandalkan buku paket tanpa diiringi dengan buku maupun media lain yang mendukung.

\section{$\square$ IMPLEMENTASI PDF ULYA DI PONDOK PESANTREN AL FITHRAH; STRUKTUR PENGELOLAAN PDF AL FITHRAH}

PDF Al Fithrah merupakan bagian dari kelembagaan yang berada dibawah naungan Ponpes Assalafi Al Fithrah dan dibawah pembinaan Kementerian Agama Kota Surabaya. Meskipun berada di lingkungan Ponpes Assalafi Al Afithrah, akan tetapi dalam pengelolaan atau secara manajemen telah memiliki struktur tersendiri. Struktur pengelolaan bersifat garis komando dengan Kepala Pondok dan kepala bidang Pendidikan Pondok pesantren. Dalam bagan dapat dilihat struktur PDF 'Ulya Al Fithrah sebagai berikut.

Tasawuf. Menurut Achmad Kunawi bahwa santri yang diterima di Ma'had 'Aly ini merupakan kader ulama yang dipersiapkan untuk menjadi Kyai di berbagai cabang Ponpes Al Fithrah. Oleh karena itu, lulusanya tidak diperbolehkan kembali ke rumah atau kampungnya sebelum melaksanakan pengbdian di Ponpes terlebih dahulu. 


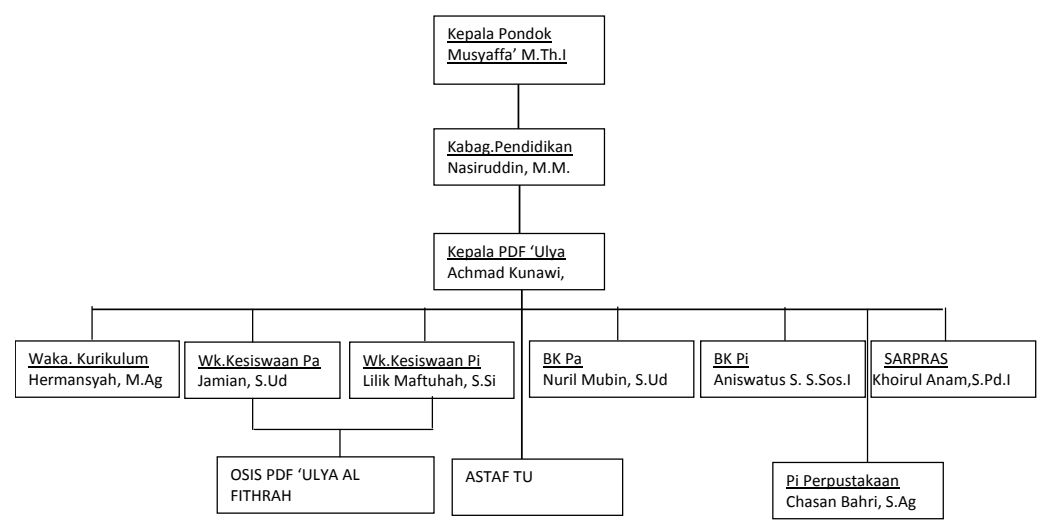

Selain pengelola yang terdapat pada struktur di atas, juga terdapat tenaga pendidik dan kependidikan yang mengelola dalam pembelajaran PDF. Secara keseluruh jumlah tenaga pendidik dan kependidikan adalah 59 orang. Dari jumlah tersebut terdiri atas 4 orang tenaga kependidikan dengan tingkat pendidikan 1 orang dari MA dan 3 orang Sarjana S.1. Adapun untuk tenaga pendidik berjumlah 55 orang dengan tingkat pendidikan MA berjumlah 1 orang sebagai Walikelas, 34 orang S.1, dan 20 orang Sarjana S.2. Dari jumlah tersebut mengelola santri (peserta didik) berjumlah 906 santri putra dan putri dan 129 santri Isti'dad sebagai santri persiapan 1 tahun sebelum memasuki PDF Ulya. 


\section{$\square$ JUMLAH SANTRI PDF AL FITHRAH}

Secara keseluruhan jumlah santri adalah 906 santri (belum termasuk santri Isti'dad yang jumlah dan keberadaan santri dinamis). Dari jumlah tersebut terbagi dalam 2 kategori, yaitu santri laki-laki dan santri perempuan dengan gedung yang terpisah. Secara garis besar jumlah santri tersebut dapat dilihat pada diagram berikut.

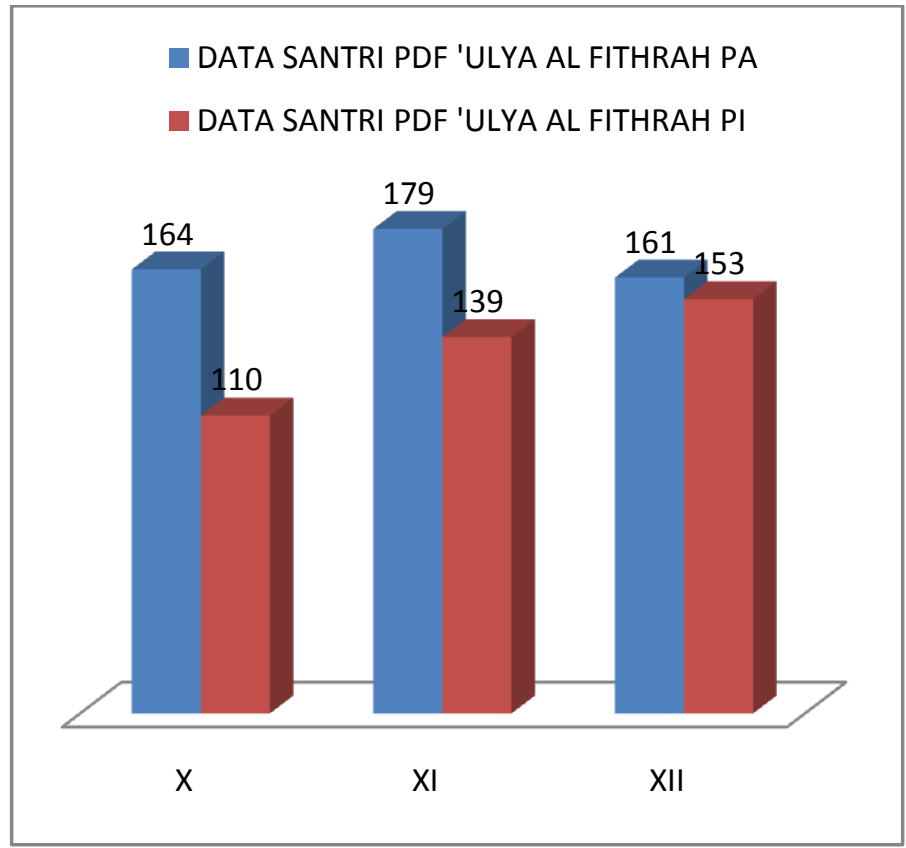

Dari jumlah tersebut terbagi dalam 13 kelas santri putra dan 12 kelas santri putri. Jumlah tersebut secara rinci dapat dilihat pada tabel berikut. 


\section{Tabel jumlah Santri dalam setiap kelas}

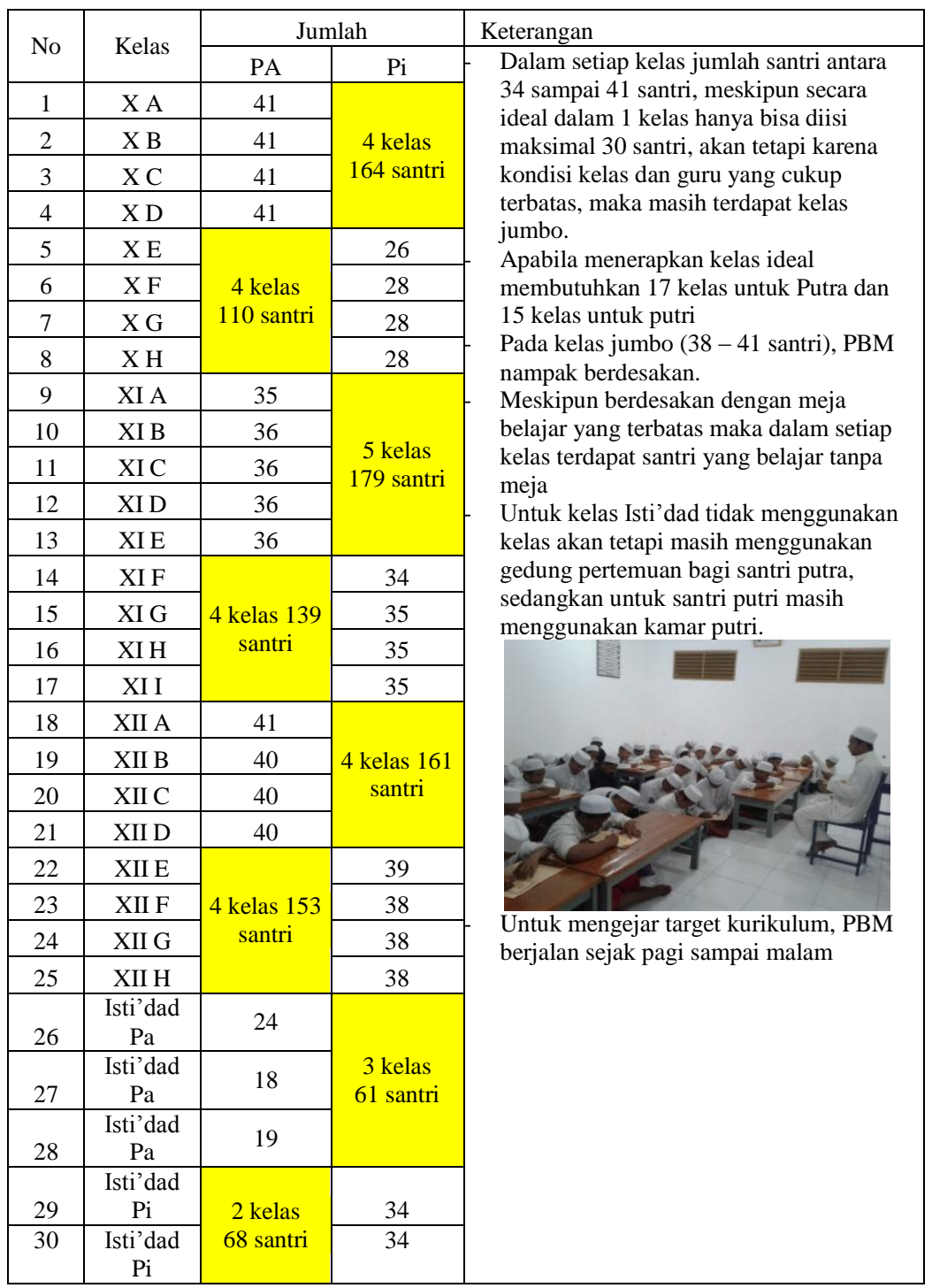




\section{$\square$ KURIKULUM PDF AL FITHRAH}

Kurikulum pembelajaran di PDF Al Fithrah secara umum terbagi atas kurikulum pendidikan agama yang bersumber dari kutubut at thurats dan dari mata pelajaran umum sesuai dengan regulasi yang ada. Disamping itu terdapat berbagai kegiatan yang harus diikuti oleh santri diluar kurikulum yang ditetapkan oleh pemerintah, yaitu kegiatan pondok pesantren. Kegiatan ponpes ini dapat dikatakan merupakan kurikulum yang tersembunyi (hidden curriculum) karena terprogram, tersusun, dan terjadwal sebagaimana dalam pembelajaran di kelas.

Dalam kerangka dasar kurikulum yang disusun ditegaskan bahwa landasan filosofis yang dijadikan pijakan dalam pengembangan kurikulum satuan PDF adalah sebagai berikut

1. Pendidikan keagamaan Islam pada satuan PDF didasarkan pada tradisi kultural yang ada di pesantren. Pengembangan kurikulum pada satuan jenis ini berbasis pada penguasaan kitab kuning yang merupakan salah satu karakteristik pesantren di tanah air dalam upaya mencetak kader ulama yang mutafaqqih fid din yang bertumpu pada nilai-nilai kultural yang moderat (tasamu).

2. Kurikulum PDF dikembangkan dalam kerangka dasar yang menempatkan peserta didik sebagai subjek pengetahuan. Kurikulum diarahkan untuk dapat mengembangkan kapasitas peserta didik sebagai pribadi yang bukan hanya sekedar mendapatkan 
pengetahuan keagamaan dari Kyai atau ustadz, tetapi juga dapat memperoleh dan mengembangkan pengetahuan melalui interaksi dengan sesama santri, masyarakat, atau sumber belajar lainnya (Profil: 40).

Dengan kerangka dasar dan landasan filosofis diatas, PDF Ulya Al Fithrah menyusun struktur kurikulum dengan memperhatikan kompetensi inti (KI), Mata pelajaran, beban belajar, kalender pendidikan, dan kompetensi dasar (KD). Deskripsi kurikulum yang telah disusun oleh PDF 'Ulya Al Fitrah adalah sebagai berikut.

\section{KOMPETENSI INTI (KI)}

Kompetensi Inti (KI) PDF tingkat 'Ulya merupakan tingkat kemampuan untuk mencapai Standar Kompetensi Lulusan (SKL). Menurut Hermansyah (Waka Kurikulum) bahwa Kompetensi untuk PDF 'Ulya terlalu tinggi sehingga SKL yang harus dicapai sukup berat. Oleh karena itu kemungkinan ketercapaian secara ideal agak sulit meskipun para santri sudah terbiasa dengan kondisi belajar yang tidak mengenal waktu dan terbiasa dengan tradisi kultural dan struktural dalam berbagai kondisi. Santri terbiasa dengan kegiatan kepesantrenan dan selalu menaati aturan tertulis maupun tidak tertulis dari pesantren. Tradisi sam'an (mendengarkan), tho'atan (menaati), tashdiq (membenarkan), wal ihktiroom (dan memuliakan) seluruh perintah dan perilaku Kyai telah membentuk karakter santri. Dengan demikian, kompetensi inti yang harus dicapai santri kemungkinan besar akan tercapai. Rumusan kompetensi inti (KI) yang ditetapkan adalah; 
a. Kompetensi Inti - 1 (KI-1) untuk kompetensi inti sikap spiritual

b. Kompetensi Inti - 2 (KI-2) untuk kompetensi inti sikap sosial

c. Kompetensi Inti - 3 (KI-3) untuk kompetensi inti pengetahuan, dan

d. Kompetensi Inti - 4 (KI-4) untuk kompetensi inti keterampilan

Uraian tentang kompetensi inti (KI) pada jenjang PDF 'Ulya adalah sebagai berikut.

\section{Kompetensi Inti Kelas 1, 2, dan kelas 3 PDF Ulya}

a. Menghayati dan mengamalkan ajaran agama Islam

b. Menghayati dan mengamalkan perilaku jujur, disiplin, tanggunjawab, peduli (gotong royong, kerjasama, toleran, damai), santun, responsif dan pro aktif menunjukan sikap sebagai bagian dari solusi atas berbagai permasalahan

c. Memahami, menerapkan, menganalisis pengetahuan faktual, konseptual, prosedural berdasarkan rasa ingintahunya tentang ilmu pengetahuan, tekonologi, seni, budaya, dan humaniora dengan wawasan kemanusiaan, kebangsaan, kenegaraan, dan peradaban terkait penyebab fenomena dan kejadian, serta menerapkan pengetahuan prosedural pada bidang kajian yang spesifik sesuai dengan bakat dan minatnya untuk memcahkan masalah. 
d. Mengolah, menalar, dan menyaji dalam ranah konkret dan ranah abstrak terkait dengan pengembangan dari yang dipelajari di pesantren secara mandiri dan mampu menggunakan metode sesuai kaidah keilmuan

\section{MATA PELAJARAN}

Mata pelajaran yang masuk dalam struktur kurikulum PDF 'Ulya terdiri atas kelompk mata pelajaran keagamaan Islam, pendidikan umum, dan muatan lokal. Struktur kurikulum tersebut adalah sebagai berikut.

\begin{tabular}{|c|c|c|c|c|}
\hline \multirow{2}{*}{\multicolumn{2}{|c|}{ KOMPONEN MATA PELAJARAN }} & \multicolumn{3}{|c|}{$\begin{array}{l}\text { Kelas dan Alokasi Waktu per } \\
\text { Minggu }\end{array}$} \\
\hline & & 1 & 2 & 3 \\
\hline \multicolumn{5}{|c|}{ A. Keagamaan Islam } \\
\hline 1 & Al Qur'an & 2 & 2 & 2 \\
\hline 2 & Tafsir - Ilmu Tafsir & 4 & 4 & 4 \\
\hline 3 & Hadits - Ilmu Hadits & 4 & 4 & 4 \\
\hline 4 & Tauhid & 2 & 2 & 2 \\
\hline 5 & Fiqh - Ushul Fiqh & 4 & 4 & 4 \\
\hline 6 & Akhlak - Tasawuf & 2 & 2 & 2 \\
\hline 7 & Tarikh & 2 & 2 & 2 \\
\hline 8 & Bahasa Arab & 3 & 3 & 3 \\
\hline 9 & Nahwu Sharf & 4 & 4 & 4 \\
\hline 10 & Balaghah & 2 & 2 & 2 \\
\hline 11 & Ilmu Kalam & 2 & 2 & 2 \\
\hline 12 & Ilmu Arudh & & 2 & 2 \\
\hline 13 & Ilmu Mantiq & 2 & 2 & 2 \\
\hline 14 & Ilmu Falak & & 2 & 2 \\
\hline \multicolumn{5}{|c|}{ B. Pendidikan Umum } \\
\hline 15 & Pendidikan Kewarganegaraan & 2 & 2 & 2 \\
\hline 16 & Bahasa Indonesia & 2 & 2 & 2 \\
\hline 17 & Matematika & 2 & 2 & 2 \\
\hline 18 & Ilmu Pengetahuan Alam & 2 & 2 & 2 \\
\hline 19 & Seni Budaya & 2 & 2 & 2 \\
\hline \multicolumn{2}{|c|}{ C. Muatan Lokal } & 10 & 6 & 6 \\
\hline \multicolumn{2}{|c|}{ Jumlah } & 53 & 53 & 53 \\
\hline
\end{tabular}


Keterangan:

1. Struktur kurikulum PDF 'Ulya terdiri atas 19 mata pelajaran dan muatan lokal

2. Mata pelajaran kelompok keagamaan Islam (A) dan kelompok pendidikan umum (B) merupakan kelompok mata pelajaran yang muatan dan acuanya dikembangkan oleh pusat berdasarkan informasi yang diperoleh dari penyelenggara pendidikan diniyah yang sudah ada

3. Komponen muatan lokal (C) merupakan kegiatan kurikuler untuk mengembangkan kompetensi yang disesuaikan dengan ciri khas, potensi dan keunggulan yang dimiliki oleh suatu pesantren yang materinya menuntut untuk dijadikan sebagai mata pelajaran tersendiri. Substansi muatan lokal ditentukan oleh satuan pendidikan diniyah. Muatan lokal merupakan mata pelajaran sehingga satuan pendidikan diniyah harus mengembangkan Kompetensi Dasar untuk setiap jenis muatan lokal yang diselenggarakan. Satuan PDF Ulya dapat menyelenggarakan satu atau beberapa mata pelajaran muatan lokal setiap tahun pelajaran.

4. Jam pembelajaran per minggu untuk setiap pelajaran dialokasikan sebagaimana tertera dalam struktur kurikulum. Satun pendidikan dapat menambah jumlah jam pembelajaran sesuai dengan kebutuhan belajar peserta didik dan/atau kebutuhan akademik, sosial, budaya, atau faktor lain yang dianggap pentin.

5. Satu jam pelajaran beban belajar tatap muka adalah 45 menit. 


\section{BEBAN BELAJAR}

Beban belajar yang harus diikuti oleh peserta didik dirumuskan dalam bentuk satuan waktu yang dibutuhkan peserta didik untuk mengikuti program pembelajaran melalui tatap muka, penugasan terstruktur, dan kegiatan mandiri tidak terstruktur. 1) Kegiatan tatap muka merupakan kegiatan pembelajaran yang berupa interaksi antara peserta didik dengan pendidik. Beban belajar kegiatan tatap muka per minggu dilakukan 53 jam pelajaran. 2) Penugasan terstruktur merupakan kegiatan pembelajaran yang berupa pendalaman materi pembelajaran oleh peserta didik yang dirancang oleh pendidik untuk mencapai kompetensi yang telah ditetapkan, 3) kegiatan mandiri tidak terstruktur kegiatan pembelajaran yang berupa pendalaman materi pembelajaran oleh peserta didik yang waktu penyelesaianya diatur sendiri oleh peserta didik. Beban belajar penugasan terstruktur dan kegiatan mandiri pada PDF Ulya maksimal $60 \%$ dari kegiatan tatap muka mata pelajaran yang bersangkutan.

Secara terstruktur beban belajar yang harus dicapai oleh peserta didik PDF 'Ulya adalah sebagai berikut.

a. Beban belajar satu minggu untuk kelas 1, 2, dan 3 adalah 53 jam pelajaran

b. Durasi setiap jam pelajaran memiliki beban belajar tatap muka 45 menit

c. Beban belajar kelas 1 dan 2 dalam 1 semester minimal 18 minggu 
d. Beban belajar di kelas 3 semester ganjil 18 minggu dan semester genap minimal 14 minggu

e. Pelaksanaan program pendidikan menggunakan sistem paket dengan penyelesaian selama 3 tahun. Program percepatan (akselerasi) dapat diselenggarakan untuk mengakomodasi peserta didik yang memiliki potensi kecerdasan dan bakat istimewa.

f. Satuan PDF Ulya dimungkinkan dapat menggunakan SKS dengan panduan diuraikan secara khusus dalam dokumen tersendiri.

\section{KALENDER PENDIDIKAN}

Kalender pendidikan adalah pengaturan waktu untuk kegiatan pembelajaran peserta didik selama satu tahun pelajaran. Cakupan kalender pendidikan adalah permulaan tahun pelajaran, waktu pembelajaran efektif, dan hari libur. Kalender pendidikan yang diselenggarakan PDF 'Ulya adalah

a. Satuan PDF 'Ulya meyusun kalender pendidikan sesuai dengan kebutuhan setempat, karakteristik pesantren, kebutuhan peserta didik dan masyarakat dengan memperhatikan kalender pendidikan sebagaimana yang dimuat di dalam dokumen.

b. Permulaan tahun pelajaran adalah waktu dimulainya kegiatan pembelajaran pada awal tahun pelajaran pada setiap satuan pendidikan. Permulaan tahun pelajaran adalah bulan Syawal setiap tahun berahir pada bulan Sya'ban tahun berikutnya. 
c. Waktu libur adalah waktu yang ditetapkan untuk tidak diadakan kegiatan pembelajaran terjadwal pada satuan pendidikan. Waktu libur dapat berbentuk jeda tengah semester, jeda antar semester, libur ahir tahun pelajaran, hari libur keagamaan, hari libur umum termasuk hari-hari libur besar nasional dan hari libur khusus.

\section{KOMPETENSI DASAR (KD)}

Kompetensi Dasar dirumuskan untuk mencapai kompetensi inti (KI). Kompetensi Dasar juga mencerminkan kedalaman muatan kurikulum pada stuan PDF 'Ulya. Rumusan Kompetensi Dasar dikembangkan dengan memperhatikan karakteristik dan kemampuan peserta didik dan kekhasan masing-masing mata pelajaran.

\section{口 TUJUAN DAN RUANG LINGKUP MATA PELAJARAN}

Tujuan dan ruang lingkup mata pelajaran yang diselenggarakan di PDF 'Ulya Al Fithrah disesuaikan dengan regulasi yang ada sehingga tidak berbeda dengan PDF yang ada di seluruh Indonesia. Apalagi PDF Ulya adalah lembaga pendidikan formal baru yang berada di pondok pesantren salafiyah $^{6}$ dengan program langsung dari Kementerian

\footnotetext{
${ }^{6}$ Pendidikan Diniyah Formal diselenggarakan berdasar pada SK Dirjen Pendidikan Islam No. 5839 Tahun 2014 Tentang Pedoman Pendirian Pendidikan Diniyah Formal. Dalam SK tersebut dipersaratkan antara lain bahwa Ponpes boleh menyelenggarakan PDF dengan sarat memiliki ijin operasional Pesantren dari Kementerian Agama Kabupaten/Kota, memiliki AD/ART, memiliki santri mukim dan belajar
} 
Agama RI (Top Down). Tujuan dan ruang lingkup mata pelajaran terbagi atas kelompok mata pelajaran keagamaan Islam dan kelompok mata pelajaran pendidikan umum.

\section{KELOMPOK MATA PELAJARAN KEAGAMAAN ISLAM}

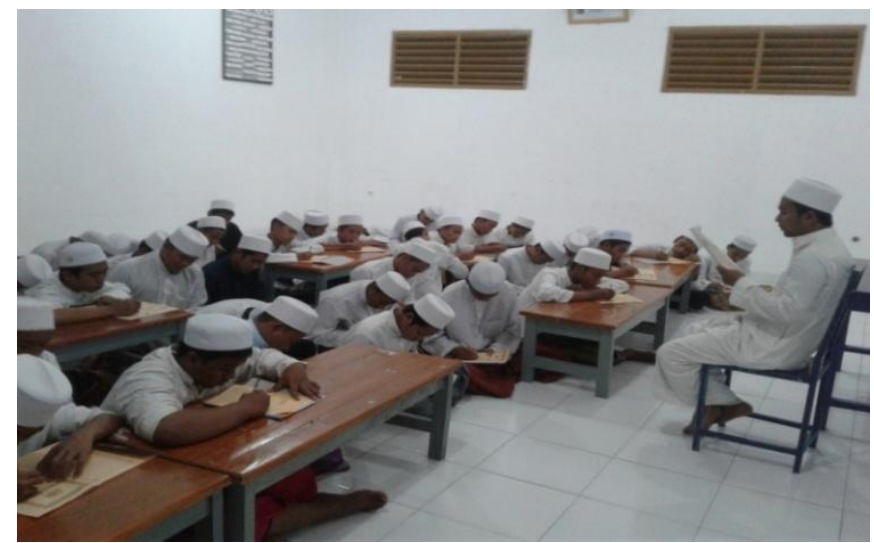

Model Pembelajaran mata pelajaran keagamaan Islam (kutub at-turats) di PDF Ulya Al Fithrah

pada pesantren yang bersangkutan minimal 300 orang pada setiap tahun selama 10 tahun, mendapat rekomendasi dari Kanwil Kementerian Agama, memiliki jumlah dan kualifikasi pendidik dan tenaga kependidikan yang memadai, memiliki calon peserta didik minimal 30 orang, memiliki kurikulum pendidikan diniyah formal, memiliki sistem evaluasi, memiliki sumber pembiayaan untuk kelangsungan pendidikan paling sedikit untuk 1 pelajaran berikutnya, memiliki sarana dan prasarana pembelajaran yang berada di lingkungah pesantren, dan melampirkan rencana induk pengembangan. Adapun diantara persaratan teknis antara lain kualifikasi pendidikan bagi Pendidik dan Kepala PDF minimal S.1. Dari hasil FGD yang melibatkan Ponpes salafiyah di Kota Surabaya bahwa persaratan terutama harus memiliki santri mukim minimal 300 orang pada setiap tahun selama 10 tahun terlalu berat karena banyak santri yang berasal dari wilayah sekitar (tidak mukim). 
Kelompok mata pelajaran Keagamaan Islam memiliki tujuan, ruang lingkup, dan kitab rujukan. Yang termasuk dalam kelompok mata pelajaran ini adalah sebagai berikut.

\section{a. Al-Qur'an}

Tujuan dari mata pelajaran al Qur'an agar peserta didik memiliki kemampuan antara lain;

1) Memperoleh keyakinan terhadap Allah SWT

2) Mengembangkan kemampuan dalam menghafal juz 'Amma dan surah-surah pilihan al Qur'an

3) Meningkatkan kemampuan membaca dengan standar teori tahsin tartil

4) Meningkatkan kemampuan menulis ayat-ayat al Qur'an dengan Rasm Imla'i maupun Rasm Utsmani

5) Meningkatkan kesadaran untuk memahami arti dan kandungan ayat-ayat al Qur'an untuk diterapkan dalam kehisupan sehari-hari

6) Memperoleh bekal pengetahuan dan keterampilan membaca, menulis, menghafal dan mengartikan juz Amma dan surah-surah pilihan sebagai bekal dalam kehidupan bermasyarakat, berbangsa dan bernegara

7) Sebagai bekal untuk menjadi imam shalat agar diperkaya dengan ayat-ayat pilihan

Adapun ruang lingkup mata pelajaran al Qur'an adalah

1) Tahsinut Tilawah berupa praktek membaca al Qur'an bin Nazhar 30 juz dengan menjelaskan dan mengaplikasikan ilmu-ilmu tajwid 
2) Tahfidzul Qur'an berupa hafalan al Qur'an juz 30 serta beberapa surah pilihan yang meliputi surah as Sajadah, Yasin, ad-Dukhan, al-Mulk, alWaqi'ah, dan al-Kahfi.

Kitab yang dijadikan sumber rujukan dalam mata pelajaran al Qur'an dan bidang Tahfidzul Qur'an (6 dan 7) adalah sebagai berikut.

1) Al Jazariyah karya Syams al-Din Muhammad alJazari

2) Hidayah al Mustafid fi Ahkam al-Tajwid karya Muhammad Abi Rimah

3) Nihayah al-Qaul al-Mufid karya Muhammad Makki Nashir

4) Manar al-Huda fi Bayan al-Qaaf wa al-ibtida' karya Ahmad al-Asymuni

5) Al-Tamhid fi Ilm al-Tajwid karya Syams al-Din Muhammad al-Jazari

6) Tahfidz al Qur'an Metode Lauhun karya Dr.KH. A. Muhaimin Zen, MA

7) Metode Pengajaran Tahfidzul Qur'an di Pondok Pesantren karya Dr.KH. A. Muhaimin Zen, MA

\section{b. Tafsir-Ilmu Tafsir}

Dalam Permenag No. 1 pasal 27 ayat 3 tahun 2014 tentang Pendidikan keagamaan Islam bahwa mata pelajaran tafsir-ilmu tafsir menjadi dasar bagi peserta didik untuk dapat memahami kandungan makna kitab suci al Qur'an yang merupakan dasar pada setiap ilmu dalam ajaran agama 
Islam. Tujuan mata pelajaran ini adalah agar peserta didik memiliki kemampuan sebagai berikut.

1) Membaca dan memahami tafsir al Alqur'an dengan baik dan benar mulai dari surat al Fatihah sampai surat An-Nas berbasis kitab tafsir yang otoritatif di kalangan pesantren

2) Memahami teori dan kaidah ilmu tafsir ('ulumul Qur'an) secara mendalam berdasarkan kitab yang mu'tamad

3) Mengamalkan isi kandungan al Qur'an dalam kehidupan sehari-hari

Ruang lingkup mata pelajaran tafsir-ilmu tafsir adalah sebagai berikut

1) Tafsir al Qur'an dari surat al Fatihah sampai surah an-Nas berdasarkan kitab-kitab tafsir yang mu'tamad di kalangan pesantren terutama kitab tafsiral-Jalalayn karya Jalaluddin al Mahalli dan Jalaluddin As-Suyuthi, Marah labid karya imam Nawawi al-Bantani dan shafwatut Tafaasiir karya Muhammad Ali ash-Shabuni.

2) Teori dan kaidah-kaidah ilmu tafsir al Qur'an yang otoritatif terutama kitab al-Itqan fi 'Ulum alQur'an dan Itmam ad-Dirayah karya Jalaluddin as-Suyuthi dan kitab Mabahith fi 'Ulum al-Qur'an karya Subhi Shalih.

Kitab rujukan sebagai bahan pengayaan dalam mata pelajaran tafsir-ilmu tafsir adalah 
1) Tafsir : 1). tafsiral-Jalalayn karya Jalaluddin al Mahalli dan Jalaluddin As-Suyuthi, 2) Marah labid karya imam Nawawi al-Bantani, 3) shafwatut Tafaasiir karya Muhammad Ali ash-Shabuni.

2) Ilmu tafsir (ilmu al-Qur'an) : 1) al-Itqan fi 'Ulum al-Qur'an karya Jalaluddin as-Suyuthi, 2) Itmam ad-Dirayah karya Jalaluddin as-Suyuthi, dan 3) Mabahith fi 'Ulum al-Qur'an karya Subhi Shalih

\section{c. Hadits-Ilmu Hadits}

Penyampaian mata pelajaran hadits-ilmu hadits pada peserta didik PDF Ulya bertujuan untuk ; meningkatkan kecintaan peserta didik terhadap hadits, membekali peserta didik dengan dalil-dalil yang terdapat dalam hadits sebagai pedoman dalam menyikapi dan menghadapi kehidupan, mengingatkan pemahaman dan pengamalan hadits baik dari segi isi kandungan maupu keilmuan, dan membekali keterampilan menelusuri hadits dari sumber aslinya dan menilai secara kuantitas dan kualitas.

Ruang lingkup hadits-ilmu hadits meliputi;

1) Tema-tema yang ditinjau dari perspektif hadits dalam kitab Riyadh al-Shalihin tentang berakhlak dengan sifat terpuji dan menjauhi sifat tercela seperti ikhlas, tawbah, shabar, muraqabah, taqwa, yaqin, tawakkal, istiqamah, al-mubaadarah ila al-khayr, al-mujaahadah, al-hats 'ala alizdiyaat min al-khayraat, katsrat thuruq al-khayr, iqtishad, muhaafazah 'ala al-a'mal, al-amru bi al- 
muhaafzhah 'ala al-sunnah, wujub al-inqiyad, alnahyu 'an a-bida', fiiman sanna sunnatan, aldilalah 'ala khayrin, ta'awun 'ala al-birri wa altaqwa, al-nashihah, al amru bi al-ma'ruf, ada' alamanah, dll.

2) Masalah dasar-dasar ilmu hadits meliputi; Sejarah ilmu hadits dan macamnya, Pengertian hadits, sunnah, khabar, atsar, dan hadits qudsi, Macam-macam hadits dilihat sampainya pada kita; mutawatir, shahih, hasan, dan dha'if, Khabar mardud dan macam-macamnya, Hadits-hadits yang berserikat antara shahih dan makbul, Persaratan periwayat dan al-jarh wa al-ta'dil, Periwayat dan adabnya tahammul wa ada' alhadits, Isnad dan yang berkaitan dengan isnad, Biografi para perawi hadits, dan Takhrijul hadits

Kitab rujukan yang menjadi dasar dari penyampaian materi dalam hadits-ilmu hadits adalah kitab Riyadh alShalihin karya al-Imam Muhyi al-Din al-Nawawi. Untuk kelas 1 sebagai alternatif dapat menggunakan Mukhtar al-haadits al-Nabawiyah wa al-Hikam al-Muhammadiyah karya alSyaikh Ahmad al-Hasymi dan kitab al-Jami' al-Saghir karya Jalaluddinash-Shuyuthi. Namun demikian kitab sebagai rujukan utama adalah Syarh al-Manshuumah al-Baiquniyyah fi musthalah al-Hadits karya Athiyah al-Ajhuri. Sedangkan untuk kelas 2 dan 3 adalah kitab Manhaj Dzawi al-Nazhar fi Syarh Manzhumah al-Atsar karya Muhammad Mahfuzh alTermasi dan kitab al-Manhal al-Lathief fi Ushul al-Hadits alSyarif karya Muhammad al-Maliki. 


\section{d. Tauhid}

Tujuan pembelajaran pada mata pelajaran Tauhid adalah 1) memantapkan akidah melalui pemberian, pemupukan, dan pengembangan pengetahuan, penghayatan, pengamalan, pembiasaan, serta pengalaman peserta didik tentang alkidah Islam sehingga menjadi manusia muslim yang terus berkembang keimanan dan ketaqwaanya kepada Allah Swt., 2) memotivasi peserta didik untuk mempelajari dan mempraktekan ajaran akidah Islam yang inklusif dalam bentuk pembiasaan perilaku kehidupan sehari-hari, dan 3) mempersiapkan peserta didik mampu membaca naskah tentang materi tauhid berbahasa Arab (kitab kuning) tingkat menengah atas sehingga siap melanjutkan ke pendidikan yang lebih tinggi.

Ruang lingkup mata pelajaran Tauhid adalah sebagai berikut;

1) Pengertian, objek kajian, dan kegunaan ilmu tauhid

2) Hubungan antara iman dan islam serta hal-hal yang merusak iman

3) Hukum akal; wujub, mustahil, dan jawaz

4) Bertauhid dalam sifat dan asma' al-husna menurut ahlus sunnah

5) Iman kepada Allah, Malaikat, Rasul Allah, Kitab, Hari ahir, dan Qada' dan Qadar menurut ahlus sunnah 
6) Penolakan penyamaan (Syabh) nash-nash agama atau setuju penyelarasan antara nash agama dengan dalil-dalil akil kuat.

7) Sifat wajib, mustahil, dan jaiz badi Allah dan sifat wajib, mustahil, dan jaiz bagi Rasulullah dalam bingkai keimanan ahlus sunnah wal jamaah.

Rujukan kitab untuk kelas 1 adalah al-Hushun alHamidiyah karya Husain Afandi atau kitab Tuhfah al-Murid 'ala Jauharah al Taukhidiyah karya al-Bajuri. Sedangkan untuk kelas 2 dan 3 menggunakan kitab al-Dasuqi 'alaa Umm al-Barahin

\section{e. Fiqh-Ushul Fiqh}

Prinsip dari mata pelajaran ini adalah menekankan pada kemampuan cara melaksanakan ibadah dan muamalah yang benar dan baik disertai dengan kemampuan memahami cara-cara menetapkan hukum dari sumber hukum agama. Tujuan dari pembelajaran ini adalah sebagai berikut;

1) Mengetahui dan memahami prinsip-prinsip, kaidah-kaidah, dan tatacara pelaksanaan hukum Islam baik yang menyangkut aspek ibadah maupun muamalah untuk dijadikan pedoman hidup dalam kehidupan pribadi dan sosial.

2) Mengamalkan ketentuan hukum Islam dengan benar dan baik sebagai perwujudan dari ketaatan dalam menjalankan ajaran agama Islam baik dalam hubungan manusia dengan Allah Swt., dengan diri manusia itu sendiri, sesama manusia, dan makhluk lainnya maupun dengan lingkungannya. 
3) Mengenal, memahami, dan menghayati terhadap sumber hukum Islam dengan memanfaatkan suhul fiqh dan kaidah fiqh sebagai metode penetapan dan pengembangan hukun Islam dari sumbernya.

4) Menerapkan kaidah-kaidah pembahasan dalildalil syara' dalam rangka melahirkan hukum Islam yang diambil dari dalil-dalilnya untuk diamalkan dalam kehidupan sehari hari.

Ruang lingkup mata pelajaran Fiqh-Ushul Fiqh dibagi menjadi 2, yaitu ruang lingkup bidang Fiqh dan ruang lingkup Ushul fiqh. Secara lebih jelas adalah sebagai berikut;

1) Bidang Fiqh meliputi

- Istinja', wudlu, tayamum, mandi wajib, masalah haid, dan nifas

- Pembahasan tentang shalat, ancaman bagi yang meninggalkan, dna syarat rukun shalat

- Sunat ab'ad dan bay'at dalam shalat, sujud sahwi dan sujud tilawah

- Azan dan iqamah, shalat-shalat sunnah, shalat jamaah dan shalat jumat

- Jama' qashar dan qadha shalat serta tata cara shalat janazah

- Zakat perniagaan, fitrah, pengelolaan zakat, dan sedekah sunnat

- Puasa wajib dan sunnah serta pembahasan tentang i'tikaf

- Haji dan umrah, qurban dan aqiqah dalam hukum Islam

74 | Pendidikan Diniyah Formal 
- Ekonomi Islam, riba, bungan bank, qiradh, pasar modal syariah, pegadaian syariah, dan asuransi

- Sewa menyewa, pinjam meminjam, wakalah dan masalah hak syuf'ah

- Wakaf, hibah, wasiat dan wasiat wajibah dan tata cara pembagian waris

- Pernikahan, perceraian dan masalah ruju' hadhanah dan harta bersama suami istri

- Masalah pemeliharaan nashab dan problem hamil diluar nikah

- Hukum pidana Islam tentang qishas, hudud, dan takzir

- Penganiayaan, pembunuhan dan masalah diat berat dan diat ringanserta komersialisasi diat kasus TKW di Saudi Arabia

- Memahami mazab dan aliran hukum dalam fiqh Islam, dan

- Memahami persoalan pengembangan hukum Islam

2) Bidang Ushul Fiqh

- Pengertian syari'ah, fiqh dan ushul fiqh

- Penalaran dan pembahasan tentang dalil hukum

- Perbandingan antara fiqh dan ushul fiqh, kaedah fiqh dan kaedah ushul fiqh

- Konsep hukum, hakim, mahkum fih, dan maqasid al-Syari'ah

- Kategori hukum taklifi, wajib, mandhub, mubah, mahdzur, makruh, sah, dan batal 
- Hukum wadh'i, syarat, sebab, mani', sah, batal, dan fasid

- Macam-macam hukum, wajib, mandhub, mubah, mahdzur, makruh, sah, dan batal

- Kategori hukum taklifi dan hukum wadh'i, syarat, sebab, mani', sah, batal, dan fasid

- Masadir al-ahkam: al-Qur'an. Hadits, Ijma', dan Qiyas

- Istihsan, istishab, dan syar'u man qoblana dalam hukum Islam

- Istidlal dna Ijtihad, mujtahid, dan madzab fiqh serta ittiba' dan taqlid

- Syar'u manqoblana dan statusnya dalam hukum Islam

Kitab rujukan yang menjadi landasan pembelajaran mata pelajaran fiqh-ushul fiqh adalah Fathul Mu'in karya Zain al-Din al-Malibari, al-Iqna' fi Hall al-Fazh abi Syuja' karya Muhammada Al Syarbini, dan Syarh al-Mahalli 'alaa Minhaj al-Thalibin karya al-Mahalli. Sedangkan ushul fiqh menggunakan kitab Tashil al-Thuruqat fi Nazhm al-Waraqat karya Yahya al-Imriyhii untuk kelas 1, al-Luma' fi ushul alFiqh karya al-Syairazi dan Lubb al-Ushul karya al-Syaikh Zakariya al Anshari untuk kelas 2 dan kelas 3.

\section{f. Akhlak Tasawuf}

Mata pelajara akhlak tasawuf pada peserta didik PDF 'Ulya diberikan dengan tujuan mewujudkan manusia Indonesia yang berakhlak mulia dan menghindari akhlak 
tercela dalam kehidupan sehari-hari, baik dalam kehidupan individu maupun sosial, sebagai manifestasi dari ajaran dan nilai-nilai akidah dalam Islam. Tujuan kedua adalah mewujudkan manusia Indonesia yang memiliki hati yang bersih dan mampu mendekatkan diri kepada Allah Yang Maha Mulia dalam maqaamat ahwal, sebagai implementasi ajaran dan nilai-nilai tasauf akhlaqi dalam kehidupan seharihari.

Ruang lingkup mata pelajaran akhlak tasawuf meliputi;

1) Akhlak terpuji terdiri atas adab keseharian (tidur, qiyaamullail, makan dan minum), adab dalam pernikahan, adab bekerja, tata pergaulan, al-Amr bil ma'ruuf wa al-Nahy 'an al-munkar, adab nabawiyah, akhlak muhammadiyah, dan jihad al-nafs

2) Aspek tercela meliputi ghdhab, haqd, hasad, jaah, riya', kibr, dan 'ujub

3) Tasawuf meliputi rahasia basmalah, hamdalah, shalawat, dzikir dan doa, wirid, shalat berjamaah, keutamaan ilmu, tilawatil qur'an, qiyamullail, rahasia thaharah, salat, zakat, puasa, haji, rahasia tilawah al-Qur'an, rahasia makanan halal, haram, dan syubhat, uzlah, bergaul, mujahadah dan riyadhah, hakikat dunia dan kehidupan, alghurur, maqamat ahwal, (al-taubat, qana'ah, alShabr wa al-Syukr, musyahadah), konsep uzlah shuhbah, kedudukan syariat dan hakikat, definisi tasawuf, mursyd, niat, ikhlas, shidq, muhasabah, muraqabah dan tafakkur, serta dzikr al-maut. 
Kitab rujukan untuk kelas 1 adalah kitab kifayat alAtqiya wa Minhaj al-Ashfiya' karya Muhammad Syatha alDimyati atau Minhaj al-Abidinilla Jannati Rabb al-Alamin karya Imam al-Ghazali. Sedangkan untuk kelas 2 dan 3 kitab Mau'idhah al-Mu'minin min Ihya' 'Ulum al-Din karya Imam Ghazali.

\section{g. Tarikh}

Materi tarikh secara substansial terkait dengan asal usul perkembangan dan peranan kebudayaan dan peradaban Islam di masa lampau mulai dari dakwah rasulullah SAW sampai periodesasi perkembangan Islam, baik di Indonesia maupun dunia. Tujuan dari mata pelajaran tarikh adalah sebagai berikut

1) Membangun kesadaran peserta didik tentang pentingnya mempelajari landasan ajaran, nilainilai dan norma-norma Islam yang telah dibangun Rasulullah SAW dalam rangka mengembangkan kebudayaan dan perdaban Islam

2) Membangun kesadaran peserta didik tentang pentingnya waktu dan tempat yang merupakan sebuah proses dari masa lampau, masa kini, dan masa depan

3) Melatih dengan kritis peserta didik untuk memahami fakta sejarah secara benar dengan didasarkan pada pendekatan ilmiah. 
4) Menumbuhkan apresiasi dan penghargaan peserta didik terhadap peninggalan sejarah Islam sebagai bukti peradaban ummat Islam di masa lampau, dan

5) Mengembangkan kemampuan peserta didik dalam mengambil ibrah dari peristiwa-peristiwa bersejarah pada masa Rasulullah SAW, tokohtokoh berprestasi dan mengaitkan fenomena sosial, budaya, politik, ekonomi, IPTEK dan seni untuk mengembangkan kebudayaan dan peradaban Islam.

Adapun ruang lingkup mata pelajaran tarikh adalah sebagai berikut

1) Kondisi sosial bangsa Arab, kehidupan Muhammad SAW sampai diangkat menjadi rasul

2) Dakwah Rasulullah SAW sejak awal kerasulannya (secara sembunyi-sembunyi, terang-terangan, dan keluar Makkah) sampai menjelang hijra ke Madinah

3) Pembentukan masyarakat Islam sejak kehadiran Rasulullah SAW di Madinah sampai usai perang Badr

4) Pembinaan masyarakat Islamsejak berahirnya perang Badr sampai berkumpulnya seluruh musuh Islam (dalam kelompok al-ahzab) dalam perang Khandak

5) Perjuangan Rasulullah SAW dalam menyelamatkan Islam dari kepungan al-ahzab dan upaya mengembangkan dakwah Islam sesudah itu sampai terjadinya perjanjian hudaibiyah 
6) Perjuangan dakwah dan mliter Rasulullah SAW setelah perjanjian hudaibiyah sampai terjadinya Fath Makkah

7) Perjuangan akhir Rasulullah SAW dalam rangka menyempurnakan misi kerasulanya

8) Hari-hari terahir kehidupan Rasulullah SAW sampai ke Rafiq al-A'la.

Kitab rujukan mata pelajaran tarikh adalah al-Rakhiq alMaktuum karya Shafi al-rahman al-Mubarokfurri. Adapun kitab al-Sirah al Nabawiyah karya Ibn Hisyam menjadi kitab yang dianjurkan.

\section{h. Bahasa Arab}

Bahasa Arab di madrasa merupakan mata pelajaran yang masuk rumpun bahasa. Meskipun demikian secara substansi tidak terdapat perbedaan yang signifikan dilihat dari aspek tujuan pembelajaran bahasa Arab itu sendiri. Pada PDF Ulya, tujuan pembelajaran bahasa Arab agar peserta didik memiliki kompetensi linguistik, komunikasi, budaya yang dibutuhkan untuk mampu berkomunikasi aktif dalam bahasa Arab lisan maupun tulis, baik interpretif, presentasional maupun interpersonal. Adapun tujuan khusus dari mata pelajaran bahasa Arab adalah;

1) Membekali peserta didik dengan kemampuan menguasai kompoenen bahasa yang berkaitan dengan bunyi, kosa kata (mufrodat kontekstual dan ibarat ishtilahiyah) dan tarkib praktis dan fungsional. 
2) Membekali peserta didik dengan 4 keterampilan berbahasa Arabterutama keterampilan berbicara dan menulis yang dapat diterapkan secara aktif dalam berkomunikasi dengan bahasa Arab di pesantren

3) Mengembangkan kemampuan berkomunikasi lisan dan tulisan dengan penutur asli bahasa Arab dalam konteks kehidupan sehari-hari yang berterima

4) Menumbuhkan kesadaran peserta didik tentang pentingnya penguasaan bahasa Arabdalam melaksanakan tugasnya sebagai calon ulama mutafaqqihun fi al-din serta mengembangkan pemahaman tentang budaya Arab Islam dan melibatkan diri dalam keragaman budaya.

Ruang lingkup mata pelajaran bahasa Arab meliputi unsur bahasa yang menekankan pada kosa kata dan ungkapan praktis (mufrodat dan ibarat) serta struktur bahasa (Nahwu-sharf) fungsional, keterampilan berbahasa, dan budaya dalam kegiatan berbahasa. Struktur bahasa yang diajarkan berhubungan dengan fadhlal al-jumlah, nawasikh, dan bentuk-bentuk sharf pokok. Sumber utama bahan pelajaran bahasa Arab adalah kitab al-Arobiyah bayna yadayk juz III karya Abd al-Rahman al-Fauzan, dkk. dan didukung dengan materi dari kitab al-Araobiyah li al-Nasyi'in karya Mahmud Ismail al-Shini dkk. serta kitab-kitab Nahwu dan Sharf yang digunakan pada tingkatan yang sama. 


\section{i. Nahwu Sharf}

Mata pelajaran Nahwu-Sharf pada PDF 'Ulya diharapkan peserta didik mampu memahami, menyelami, dan menerapkan pengetahuan nahwu dan sharf untuk dapat dimanfaatkan untuk mengakses berbagai buku keIslaman berbahasa Arab yang menjadi rujukan studinya. Pada tingkat ini peserta didik diharapkan mampu mendemonstrasikan hafalan nadhom Alfiyah Ibnu Malik dengan lancar, mampu memahami dan menjelaskan struktur kata dan kalimat yang terdapat dalam teks berbahasa Arab.

Ruang lingkup pelajaran Nahwu-sharf merupakan pendalaman dan perluasan atas materi di tingkat wustha. Adapun kitab yang menjadi rujukan utama adalah Syarh Ibnu Aqil alaa Alfiyah Ibn Malik karya Baha' al-Din Abd al-Lah ibn Aqil. Kitab lain yang memungkinkan menjadi pengayaan adalah kitab mughni al-Labib 'an kutub al-A'arib karya Ibn Hisyam al-Anshari.

\section{j. Balaghah}

Mata pelajaran balaghah menekankan pada pemahaman dan penggunaan bahasa sastrawi termasuk yang digunakan dalam al-Aqur'an al-Karim. Tujuan secara spesifik dalam mata pelajaran balaghah ini adalah

1) Membaca dan memahami teks-teks kalam Arab baik puisi (syi'ir) maupun prosa (natsar) khususnya ayat-ayat al_Qur'an dengan baik dan benar 
2) Menyebutkan dan menjelaskan makna kata-kata atau ungkapan yang mengandung aspek-aspek balaghah dalam suatu teks

3) Mengembangkan pemahaman tentang saling keterkaitan antara bahasa dan budaya serta memperluas cakrawala budaya, termasuk budaya Arab Islami.

4) Menumbuhsuburkan potensi balaghah dalam diri peserta didik dalam berkomunikasi khususnya dalam kegiatan dakwah Islam.

Ruang lingkup mata pelajaran balaghah meliputi pembahasan fashahah, muqtadlal wal maqam, dan macammacam gaya bahasa (uslub) struktur ilmu ma'ani, gaya bahasa kiasan ilmu bayan, serta gaya bahasa pertautan dan pertentangan muhassinat ilmu ilmu badi'. Kitab rujukan yang digunakan adalah al-Jauhar al-Maknun karya Jalaluddin alSuyuthi di kelas 2 dan kelas 3.

\section{k. Ilmu Kalam}

Tujuan pemeberian mata pelajaran Ilmu kalam pada santri adalah agar memiliki kemampuan memahami dan membedakan secara faktual dan konseptual pemikiran kalam yang benar dan yang salah (sesat), memiliki sikap keberagamaan atau keberimanan yang berakidah kalam ahlussunnah waljamaah yang moderat dan penuh kasih sayang (rahmah), tetapi tetap memiliki sikap yang tegas terhadap penganut akidah dan kalam yang sesat, dan agar juga memiliki pola pikir dan pola tindak dalam mem- 
praktikan aqidah yang benar dan menjauhi aqidah yang sesat. Tujuan umum ini dijabarkan ke dalam rumusan tujuan yang diharapkan pada PDF Ulya Al Fithrah yaitu

1) Menumbuhkembangkan akidah ahlussunnah wal jamaah sebagai aqidah yang moderat dan rahma (penuh kasih sayang) sehingga tumbuh menjadi muslim Indonesia yang terus meningkatkan keimanan dan ketaqwaannya kepada Allah SWT dan menjadi cendekiawan atau ulama yang penuh tanggungjawab dan bijaksana dalam kehidupan pribadi, bermasyarakat, berbangsa, dan bernegara.

2) Memupuk diri sebagai muslim Indonesia yang beriman dan bertaqwa kepada Allah SWT dengan sikap penuh dengan rendah hati, sehingga tidak memiliki sikap klaim diri sebagai muslim yang benar dan muslim yang lain salah (bathil) serta memiliki kesempatan melanjutkan pendidikan pada jenjang yang lebih tinggi.

3) Mewujudkan diri sebagai muslim Indonesia yang berakidah ahlisunnah waljamaah dan berakhlak mulia dengan penuh kecintaan terhadap tanah air dan NKRI.

Ruang lingkup ilmu kalam adalah makna penting ilmu kalam, kelompok yang benar dan yang sesat dalam beraqidah, kewajiban mendalami ilmu kalam, memikirkan Dzat Allah SWT., sifat Allah SWT., perbuatan Allah SWT., melihat Allah SWT. dengan mata kepala di akherat, al-Qur'an 
merupakan kalam Allah bukan makhluk, Qadar, Syafaat, kebangkitan, azab kubur, al-shirath dan al-mizan, kepemimpinan Abu Bakar al-Shidiq RA. Adapun kitab rujukan adalah al-Iqtishaad fi al-I'tiqad karya Imam Ghazali untuk kelas 1, dan al-Ibanah 'an ushul al-diyaanah karya Imam Abu al-hasan al-Asyari untuk kelas 2 dan 3.

\section{Ilmu ‘Arud}

Ilmu arudh adalah ilmu bantu (alat) terutama terkait dengan syair Arab. Tujuan pemberian materi melalui mata pelajaran ilmu arudh adalah

1) Mamahami mabadi'/dasar dasar ilmu arudh dan kaidahnya

2) Memahami macam-macam wazan/bahar syair dan laqab bait

3) Memahami perubahan wazan/zihaf dan illat

4) Memahami dasar-dasar ilmu Qafiyah

5) Memahami aib qafiyah

Ruang lingkup mata pelajaran ilmu arudh adalah sebagai berikut

1) Aspek wazan dilihat dari wazan tertentu terkait dengan kebenaran, kerusakan, dan zihaf dan illat (perubahan)nya

2) Aspek Qafiyat yakni bagian ahir dari bait syair yang meliputi huruf qafiyah, haraqat qafiyah, macam-macam qafiyah, laqab qafiyah, dan aib qafiyah. 
Kitab yang menjadi rujukan adalah al-mukhtashar alsyafi 'alaa matn al-kafi karya muhammad Damanhur. Kitab ini untuk kelas 2 dan 3, sedangkan kitab lain sebagai pengayaan adalah al-mayassar fi ilm al-arudh karya $\mathrm{KH}$. Khatibul Umam.

\section{m. Ilmu Mantiq}

Ilmu mantiq merupakan kaidah-kaidah yang dijadikan pedoman untuk berfikir agar tidak keliru dan informasi yang diterima tidak salah. Tujuan materi ini adalah agar santri mampu menunjukan kemampuan berfikir logis, kritis, dan kreatif serta kemampuan analisis yang produktif sesuai dengan kaidah-kaidah penalaran yang logis. Ruang lingkup ilmu mantiq adalah konsep al-ilmu dan al-adalah, lafadz, qadhiyah, istidlal, dan lawahiq qiyas (qiyas tambahan). Kitab rujukanya adalah kitab karya Muhammad Nur Ibrahimi untuk kelas 1, dan untuk kelas 2 dan 3 al-sulam al-munawraq fi ilm al-manthiq karya Abd Rahman al-Akhdari.

\section{n. Ilmu Falak}

Ilmu falaq diberikan agar santri memiliki wawasan terhadap fenomena benda-benda langit yang senantiasa bergerak. Dengan demikian santri mampu memahami seluk beluk tata surya khususnya yang berkaitan dengan gerak edar bumi, bulan dan matahari. Tujuan secara khusus adalah:

1) memahami ketentuan nash tentang waktu-waktu ibadah

\section{6 | Pendidikan Diniyah Formal}


2) meluruskan arah kiblat dan menerapkannya melalui pendekatan rumus falakiyah

3) meningkatkan kesadaran dan pemahaman yang benar serta dapat menjelaskan secara logis terhadap sebagian perubahan fenomena alam yang oleh syariat Islam dianjurkan untuk bertaqarrub kepada Allah SWt, seperti fenomena terjadinya peristiwa gerhana matahari dan bulan.

Ruang lingkup ilmu falak meliputi tata koordinat bola bumi, tata koordinat bola langit, mengenal posisi matahari pada bola langit, dan perhitungan dan pengukuran arah kiblat, penentuan waktu shalat, dan awal bulan qomariyah syari'iyah. Kitab yang menjadi rujukan adalah al-Khulashah al-Wafiyah fi al_afalak bi Jadawil al-Lughaaritmiyah karya Zubair Umar al-Jailani.

\section{KELOMPOK MATA PELAJARAN UMUM}

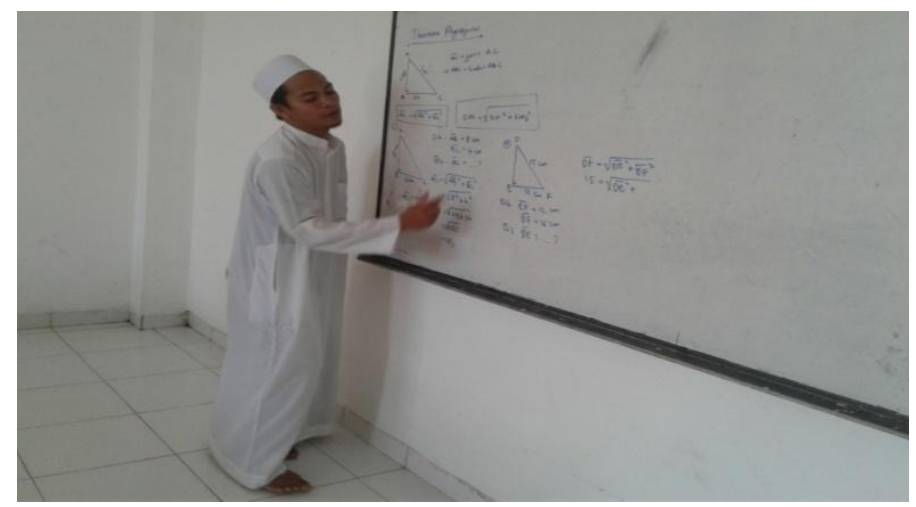

Pembelajaran Matematika di PDF Ulya Al Fithrah 
Kelompok mata pelajaran Umum yang diajarkan pada PDF Ulya adalah Pendidikan Kewarganegaraan, bahasa Indonesia, Matematika, Ilmu Pengetahuan Alam, dan Seni budaya. Dari kelima mata pelajaran terdapat mata pelajaran yang merepresentasikan dunia pondok pesantren salafiyah, yaitu pada mata pelajaran seni budaya dengan mengkaji syair-syair dan ratib. Untuk melihat secara lebih komprehensif tujuan, ruang lingkup dan rujukan materi pada mata pelajaran umum adalah sebagai berikut.

\section{a. Pendidikan Kewarganegaraan}

Pendidikan kewarganegaraa yang diajarkan di PDF Ulya memiliki karakteristik tersendiri karena diajarkan dalam kerangka nasional yang berbasis pada nilai, budaya, dan karakter pesantren. Dengan demikian, peserta didik diharapkan akan memiliki semangat kebangsaan dan cinta tanah air, mendukung demokrasi yang berkeadaban dan mendukung kesadaran hukum dan menghormati keragaman. Secara operasional tujan pembelajaran mata pelajaran pendidikan kewarganegaraan adalah

1) Mengembangkan sikap positif dan menampilkan perilaku yang mendukung semangat kebangsaan dan cinta tanah air

2) Mengembangkan sikap positif dan menampilkan perilaku yang mendukung demokrasi berkeadaban

3) Mengembangkan sikap positif dan menampilkan perilaku yang mendukung kesadaran hukum dan keragaman.

\section{8 | Pendidikan Diniyah Formal}


Ruang lingkup mata pelajaran Pendidikan Kewarganegaraan pada PDF Ulya AL Fithrah adalah sebagai berikut

1) Nilai ideal, instrumental, dan praksis silai-sila Pancasila dan UUD Negara Republik Indonesia tahun 1945

2) Integrasi Nasional dalam bingkai Bhineka Tunggal Ika

3) Nilai-nilai kultural dalam kehidupan bermasyarakat

4) Pengelolaan kekuasaan negara

5) Implementasi hukum yang berkeadilan

6) Nilai-nila HAM dan penanganan kasus-kasus pelanggaran HAM

\section{b. bahasa Indonesia,}

Bahasa Indonesia diajarkan agar peserta didik memiliki penguasaan keterampilan berbahasa yang memadai. Oleh karena itu kompetensi yang diharapkan adalah sebagai berikut.

1) Keterampilan bahasa yang ingin dicapai yaitu keterampilan menyimak/mendengarkan dengan berbagai ragam bahasa lisan dan fungsinya, keterampilan berbicara dengan menggunakan wacana lisan yang tepat, keterampilan membaca untuk memahami wacana tulis, dan keterampilan menulis untuk mengungkapkan pikiran, perasaan, dan informasi dalam bentuk teks naratifartistik, teks informatif-ekspositoris, dan teks argumentatif-persuasif. 
2) Kebahasaan dengan indkator memahami satuan bentuk dalam bahasa, memahami tata kalimat, dan memahami tata makna

3) Kesastraan dengan indikator memahami apa itu puisi, prosa, dan drama.

Secara spesifik tujuan pembelajaran bahasa Indoensia pada peserta didik PDF Ulya adalah sebagai berikut.

1) Menghargai dan bangga menggunakan bahasa Indonesia sebagai bahasa persatuan dan bahasa negara

2) Memahami karakteristik bahasa Indonesia secara baik dan mampu menggunakannya untuk berbagai tujuan

3) Menggunakan bahasa Indonesai untuk meningkatkan kemampuan intelektual, serta kematangan emosional dan sosial

4) Menggunakan bahasa Indonesia secara efektif dan efisien sesuai dengan etika yang berlaku yaitu memenuhi kaidah interpretatif dan kaidah interaktif, baik dalam ragam lisan maupun tulisan

5) Mengapresiasi karya sastra sebagai medium untuk memperluas wawasan, memperhalus budi pekerti serta meningkatkan pengetahuan dan kemampuan berbahasa

6) Menghargai dan membanggakan sastra Indonesia sebagai khazanah budaya dan intelektual manusia Indonesia 
Ruang lingkup bahasa Indonesia mencakup komponen kemampuan berbahasa dan bersastra dalam aspek keterampilan berbahasa, kebahasaan, dan kesanstran. Rujukan dalam pembelajaran bahasa Indonesia adalah bahan ajar yang berasal dari dunia Islam-pesantren, seperti karya KH.A.Mustofa Bisri, Ahmad Thohari, Emha Ainun Nadjib, Mahbub Junaidi, D. Zawawi Imron, Jamal D Rahman, dan Acep Zamzam. Pada aspek lain dapat memanfaatkan biografi lokal kiai-kiai pesantren dan atau menggunakan tradisi sastra-seni-budaya yang berkembang secara lokal.

\section{c. Matematika,}

Cabang matematika dalam dunia pesantren dengan istilah ilmu hisab. Kompetensi yang diharapkan melalu mata pelajaran matematik di PDF Ulya adalah sebagai berikut.

1) Menunjukan kemampuan berfikir logis, kritis, analitis, sistematis, kreatif, dan inovatif dalam pengambilan keputusan

2) Mengusai konsep-konsep matematika terutama konsep aritmatika dan aljabar dalam memecahkan masalah kehidupan sehari-hari dan masalahmasalah perhitungan dalam masalah fiqh zakat dan fiqh mawaris

3) Mengusai konsep dan aturan dalam logika matematika yang berguna bagi masalah pengambilan keputusan dan argumentasi serta lebih mampu menerapkannya pada disiplin ilmu mantiq 
4) Menguasai konsep-konsep statistika deskriptif sehingga mampu mengolah dan menafsirkan data-data tentang berbagai masalah menyangkut umat Islam dan dunia Islam

5) Mengusai konsep-konsep matematika terutama konsep perbandingan trigonometri dan bola bumi (salah satu bidang stereometri) untuk memperlancar pemahaman dalam ilmu falaq

6) Mengusai pengetahuan yang diperlukan untuk mengkuti pendidikan tinggi.

Adapun tujuan dari pembelajaran matematika ini adalah peserta didik memiliki kemampuan sebagai berikut

1) Memahami konsep matematika dan menjelaskan antar konsep serta mengaplikasi konsep atau algoritma secara luwes, akurat, efesien, dan tepat dalam pemecahan masalah

2) Menggunakan penalaran pada pola dan sifat, melakukan teknik matematika dalam membuat generalisasi, menyusun bukti, atau menjelaskan gagasan dan pernyataan matematika

3) Memecahkan masalah yang meliputi kemampuan memahami masalah, merancang model matematika, menyelesaikan model dan menafsirkan solusi yang diperoleh

4) Mengomunikasikan gagasan dengan simbol, tabel, diagra atau media lain untuk memperjelas keadaan atau masalah 
5) Memahami sikap menghargai kegunaan matematika dalam kehidupan, yaitu memiliki rasa ingin tahu, perhatian, dan minat dalam mempelajari matematika, serta sikap ulet dan percaya diri dalam pemecahan masalah

Ruang lingkup matematika yang diajarkan pada PDF Ulya adalah bidang aritmatika, aljabar, logika, statistika, trigonometri, dan stereometri.

\section{d. Ilmu Pengetahuan Alam}

Pembelajaran Ilmu Pengetahuan Alam (IPA) di PDF Ulya diharapkan dapat membekali peserta didik terhadap dasar pengetahuan dan perkembangan IPA dan teknologi sehingga peserta didik dapat melakukan ikhsasul waqii" lebih dalam dan luas sebelum memutuskan hyukum tertentu bagi produk-produk hasil perkembangan ilmu pengetahuan dan teknologi terutama beberapa produk yang menimbulkan kontroversi di masyarakat. Kompetensi yang diharapkan melalui mata pelajaran IPA adalah

1) Menjelaskan ruang lingkup biologi berdasarkan objek dan permasalahannya pada berbagai tingkat organisasi kehidupan

${ }^{7}$ Sebuah realistas dimana Islam diturunkan untuk berinteraksi dengan realitas-realitas obyektif yang nyata-nyata ada sebagaimana ia adanya. Selain itu ajaran-ajarannya didesign sedemikian rupa yang memungkinkannya diterapkan secara nyata dalam kehidupan manusia. 
2) Mendeskripsikan keaneka ragaman hayati Indonesia dan usaha pelestarian serta pemanfaatan sumber daya alam

3) Menjelaskan hubungan antara komponen ekosistem, aliran energi, dan mengkaitkan dengan keseimbangan lingkungan dan pelestariannya.

4) Mengidentifikasi jenis-jenis limbah dan daur ulang limbah serta membuat produk daur ulang limbah

5) Menjelaskan berbagai gangguan kesehatan tubuh dan lingkungan yang disebabkan oleh makhluk hidup dan berbagai polusi serta upaya penanggulangannya

6) Memahami kegunaan dan efek samping bahan kimia dalam kehidupan sehari-hari

7) Menjelaskan berbagai konsep dasar fisika, penerapan serta pemanfaatannya dalam kehidupan sehari-hari

8) Menjelaskan arti, prinsip dasar, jenis-jenis, peran dan implikasi teknlogi tepat guna dan bioteknologi pada sains, lingkungan, teknologi, dan masyarakat

Melalui kompetensi di atas, pembelajaran IPA bertujuan untuk

1) Meningkatkan keyakinan terhadap kebesaranb Tuhan Yang Maha Esa berdassarkan keberadaan, keindahan, dan keteraturan alam ciptaan-Nya 
2) Mengembangkan pemahaman tentang berbagai macam gejala alam, konsep dan prinsip IPA yang bermanfaat dan dapat diterapkan dalam kehidupan sehari-hari

3) Meningkatkan kesadaran untuk berperanserta dalam memelihara, menjaga, dan melestarikan lingkungan serta sumber daya alam

4) Mengembangkan pemahaman dan kemampuan IPA untuk menunjang kompetensi untuk menentukan hukum-hukum tertentu terhadap produk perkembangan ilmu pengetahuan dan teknologi

Ruang lingkup mata pelajaran IPA meliputi aspek-aspek 1) Makhluk hidup dan proses kehidupan, 2) Polusi dan limbah lingkungan, 3) Ekosistem, komponen ekosistem dan keseimbangan lingkungan, 4) Bahan kimia di sekitar, 5) Konsep dasar fisika dan pemanfaatannya, dan 6) Teknologi tepat guna dan bioteknologi. Adapun buku rujukan terdiri atas buku pegangan peserta didik untuk mata pelajaran IPA karangan Tim PD Pontren.Jakarta.Kemenag RI, dan buku pegangan siswa dan guru mata pelajaran Fisika, Kimia, dan Biologi untuk SMA/MA, Kemendikbud RI

\section{e. Seni budaya}

Pembelajaran Seni Budaya di PDF Ulya diupayakan untuk meningkatkan pemahaman peserta didik terhadap seni budaya relegi dengan segenap nilai, ajaran dan 
fungsinya dalam konteks keIslaman, sehingga peserta didik tidak saja melakukan apresiasi terhadap seni budaya, tetapi berkreasi menciptakan berbagai bentuk dan format seni budaya Islami yang relevan dengan zamanya. Dalam konteks ini pondok pesantren mengaplikasikan jargon yang menjadi sikap yaitu al-mukhaafadlatu 'ala qadiimis shalih dan juga sekaligus terjadi proses kreatif terhadap sikap al-akhdzu bi jadiidil ashlah. Adapun kompetensi yang diharapkan dari pembelajaran ini adalah peserta didik memahami berbagai ragam bentuk seni budaya yang ada dan menjadi tradisi di kalangan masyarakat muslim, khususnya kalangan madrasah dan pesantren yang menjadi sumber inspirasi dan sarana mensosialisasikan ajaran Islam. Kompetensi lain adalah peserta didik memahami kandungan makna, nilai, hikmah dan fungsi yang ada dibalik ragam bentuk kesenian yang ada dan diajarkan di kalangan masyarakat muslim.

Adapun tujuan pembelajaran ini adalah agar peserta didik

1) mengenali berbagai ragam khazanah seni budaya Islami yang ada dan berlaku di pesantren/ madrasah yang menjadi sumber kreatifitas dan akar tradisi Islamdi kalangan masyarakat.

2) memahami berbagai kandungan makna, hikmah dan bentuk seni budaya Islami serta berbagai kayfiyah dan tata aturan permainan dalam penampilan seni budaya, dan 
3) memiliki kesadaran untuk berperan serta dalam memelihara, menjaga, dan mengembangkan seni budaya relegius, mampu mengembangkan kreatifitas dan meningkatkan apresiasi terhadap seni budaya untuk menunjang kompetensi dalam menjaga dan mengembnagkan seni budaya.

Ruang lingkup pembelajaran seni budaya di PDF Ulya meliputi

1) aspek estetik yang meliputi berbagai nilai keindahan baik dalam lagu, sastra maupun format penampilan yang ada dalam seni budaya seperti tercermin dalam syair-syair shalawat dan ratib yang biasa dibaca dan disenandungkandi madrasah/pesantren dan masyarakat dalam acara dan waktu-waktu tertentu, seperti shalawat nariyah, badr, syair burdah, ratibul haddad dan symtuth dhurar, dziba' dan barzanji.

2) Aspek etikmeliputi berbagai kandungan makna, ajaran dan hikmah yang dibalik syair, syimbol dan berbagai format seni budaya seperti tercermin dalam shalawat nariyah, badr, syair burdah, ratibul haddad dan symtuth dhurar, dziba' dan barzanji,

3) Aspek historis dan kreatif terdiri atas pengamatan dan keterlibatan terhadap berbagai ragam bentuk penampilan dan format tradisi dan seni budaya lokal yang bernuansa relegi seperti hadrah, tabot, maulid, sekaten, dan beberapa jenis seni budaya lainnya yang terjadi di masyarakat yang ada di sekitar lembaga PDF, dan 
4) Aspek spiritual dan ritual meliputi berbagai kandungan hikmah dari khizb dan aurad yang merupakan bagian dari khazanah seni budaya.

Rujukan buku mata pelajaran yang disusun adalah dari kitab-kitab, yaitu Simth al_durar karya al-Habib Ali bin Muhammad Al-Habsy, Ratib al-Haddad karya al-Habib Abdullah bin Alwi al-Hadaad, Syair al-Burdah karya al-Imam Muhammad bin Zaid Al-Bushiri, Al Barzanji karya Ja'far bin Husain al-Barzanji, Al-Diba'i karya al-Imam Abd alRahmanAl-Diba'i, Syams Al-Ma'arif karya al-Imam Ahmad bin Ali al-Buni, dan Syawariq al-Anwar Min Ad'iyah al-Saadah alAkhyar karya Muhammad bin Alwi al-Maliki. 


\section{Bab IV \\ PENDIDIKAN DINIYAH FORMAL; MENERUSKAN PERJUANGAN ULAMA SALAFUSSHOLIH}

Secara umum pondok pesantren salafiyah merupakan lembaga pendidikan non formal yang sarat dengan kajian kitab kuning. Kitab ini karya ulama salaf yang terus dikaji dan ditransformasikan pada santri agar memiliki penguasaan sekaligus meneruskan cita-cita ulama salafush al-shalihin. Begitu juga yang dilakukan oleh Ponpes Assalafi Al Fithrah dengan visinya disamping mensuritauladani akhlaqul karimah baginda habibillah rasulillah muhammad saw. juga meneruskan perjuangan salafush sholih, terdepan dalam berilmu dan beragama serta mampu menghadapi tantangan zaman.

Melihat visi meneruskan perjuangan salafush sholih secara implisit dan eksplisit ponpes Al Fithrah merupakan 
ponpes yang akan mencetak kader ulama untuk meneruskan perjuangan ulama sebelumnya (salafush sholih). Ponpes dibawah Yayasan Al-Khidmah Indonesia (YAKIN) dan Nomor Statistik Pondok Pesantren Salafiyah pada Kandepag: 042.3578.14.003 diharapkan menjadi salah satu pusat kaderisasi ualam yang ada di Indonesia. Hal ini dikarenakan Ponpes Al Fithrah telah tersebar di berbagai daerah seperti Ponpes Al Fithrah Gresik, Al Fithrah Semarang, Al Fithrah Lamongan, Al FIthrah Indaramayu, Al Fithrah Batang, Al Fithrah Yogyakarta, Al Fithrah Balongpanggang Gresik, Al Fithrah Tuban, Al Fithrah Pakal Surabaya, PP. Bustanul Arifin Menganti dan PP. Miftahul Huda Ngroto.

Langkah Ponpes Al Fithrah dalam mencetak kader ulama dengan menyelenggarakan pendidikan formal, non formal maupun pendidikan khusus. Lembaga pendidikan formal yang diselenggarakan disesuaikan dengan pesantren sebagai lembaga kader ulama, yaitu

1. Isti'dad Ula diperuntukan khusus santri lulusan SD/MI yang belum mampu membaca al-Qur'an dengan baik dan belum mampu menulis serta membaca tulisan pegon dengan baik. Standar pendidikan ini 1 tahun.

2. Isti'dad Wustha diperuntukan khusus santri lulusan SMP/MTs yang belum mampu membaca al_qur'an dengan baik, belum mampu menulsi dan membaca tulisan pegon dengan baik, serta belum mampu memahami dan mengaplikasikan gramatika Arab. Standar pembelajaran ini $1 \mathrm{~s} / \mathrm{d} 2$ tahun. 
3. Pendidikan Diniyah Formal (PDF) Wustha al fithrah

4. Pendidikan Diniyah Formal (PDF) Ulya al-Fithrah, dan

5. Ma'had Aly al fithrah.

Untuk pendidikan diniyah non formal diselenggarakan untuk memenuhi kebutuhan masyarakat sekitar, seperti Taman Pendidikan al-Qur'an (TPQ) al fithrah, Madrasah Diniyah (Madin) MI Takmiliyah al fithrah, MTs Takmiliyah, dan Aliyah Takmiliyah al-Fithrah, serta Ma'had Jami'ah al Fithrah. Adapun pendidikan khusus adalah program khusus Ramadhan, Astracil dan Astricil sebagai pesantren khusus anak-anak usia dini dengan program hafalan aurad (wiridan setelah salat), hafalan juz 'Amma, ekstra banjari, berlatih berbicara bahasa Arab dan bahasa Inggris.

Kekuatan Pondok pesantren untuk mencetak kader ulama secara terstruktur telah dilakukan dengan menyelenggarakan lembaga pendidikan formal dari Madrasah Ibtidaiyah Takmiliyah, PDF Wustha, PDF 'Ulya, dan Ma'had 'Aly. Oleh karena itu apabila santri mengikuti langkah-langkah pendidikan dari tingkat Takmiliyah sampai ke tingkat Ma'had Aly maka diharapkan menjadi kader ulama untuk meneruskan perjuangan ulama salaf. Apalagi santri Ma'had Aly adalah santri pilihan yang memang secara khusus diproyeksikan untuk menjadi ulama. Proyeksi ini secara terstruktur telah diprogram yaitu santri setelah selesai studi Ma'had 'Aly harus mengabdi terlebih dahulu minimal selama 
1 tahun untuk mengajar di Ponpes al Fithrah di berbagai cabang yang dimiliki.

Meskipun Ponpes Al Fithrah memiliki langkah-langkah terstruktur untuk mencetak kader ulama yaitu sampai ke tingkat Ma'had Aly, akan tetapi proses kaderisasi yang dilakukan melalui penyelenggaraan PDF Ulya dapat dijadikan bahan untuk melanjutkan perjuangan ulama salaf. Hal ini dikarenakan bahan atau materi yang disampaikan melalui mata pelajaran yang dimuat dalam kurikulum pendidikan keagamaan Islam PDF cukup tinggi. Menurut Santri Ma'had Aly, bahwa kitab-kitab yang harus diselesaikan oleh santri PDF Ulya sangat tinggi bahkan sejajar dengan Ma'had Aly, hal ini dikarenakan santri dituntut harus menyelesaikan kitab-kitab yang dirujuk sebagai kitab utama.

Para santri belajar tidak hanya sesuai jadwal pembelajaran di kelas pada umumnya, akan tetapi melebihi jam belajar yang ditetapkan yaitu 18 jam dalam 1 minggu. Menurut Hermansyah, bahwa secara rasional cukup berat bagi santri menyelesaikan materi melalui kitab-kitab utama, akan tetapi karena kebiasaan atau kultur santri yang terbiasa belajar sampai malam, maka santri dapat menyelesaikan sesuai dengan target. Bagi santri mukim Ponpes Al Fithrah yang dijadikan sarat penyelenggaraan PDF setiap hari memiliki aktifitas sebagai berikut; 


\begin{tabular}{|l|l|l|}
\hline \multicolumn{3}{|c|}{ JADWAL KEGIATAN SANTRI MENETAP / MUKIM } \\
\hline No & Waktu kegiatan & \multicolumn{1}{c|}{ Jenis kegiatan } \\
\hline 1 & $04.15-05.40$ & Tarhim dan Salat Subuh \\
\hline 2 & $05.40-06.25$ & Membaca al-Qur'an, ngaji kitab, senam \\
\hline 3 & $06.25-06.35$ & Salat Isyraq, Dhuha, dan Isti'adzah \\
\hline 4 & $06.35-07.15$ & Sarapan pagi \\
\hline 5 & $07.15-07.30$ & Persiapan sekolah \\
\hline 6 & $07.30-11.50$ & Masuk sekolah jam 1 s/d 6 \\
\hline 7 & $11.50-12.40$ & Salat Dhuhur dan makan siang \\
\hline 8 & $12.00-15.00$ & Istirahat \\
\hline 9 & $15.00-15.20$ & Persiapan salat Ashar \\
\hline 10 & $15.20-17.00$ & $\begin{array}{l}\text { Ngaji sorogan, membaca al-Qur'an, kursus } \\
\text { bahasa Arab dan bahasa Inggris }\end{array}$ \\
\hline 11 & $17.00-17.30$ & Persiapan salat Maghrib \\
\hline 12 & $17.30-19.20$ & Salat Maghrib dan membaca Burdah \\
\hline 13 & $19.20-20.20$ & Salat Isya \\
\hline 14 & $20.20-20.50$ & Makan malam \\
\hline 15 & $20.50-21.00$ & $\begin{array}{l}\text { Persiapan Majlis } \\
\text { pembahasan Kajian Ilmiah (MKPI) }\end{array}$ \\
\hline 16 & $21.00-00.00$ & MKPI \\
\hline 17 & $00.00-01.00$ & Salat malam (Tasbih, Tahajjud dan witir) \\
\hline 18 & $01.00-03.30$ & Istirahat \\
\hline
\end{tabular}

Jadwal di atas belum termasuk kegiatan wajib yang harus diikuti santri mukim yaitu Salat berjamaah dan diikuti salat sunnah qabliyah/ba'diyah, mengikuti salat sunnah yang telah ditetapkan, mengikuti manakib ahad pertama dan acara ahad kedua dari jam 07.00 sampai menjelang dhuhur, mengikuti pengajian al-Qur'an atau kitab sesuai dengan tingkatan kitab dan kemampuan, mengikuti sekolah dan dirosah idlofi.

Beban belajar santri PDF diakui oleh beberapa santri PDF maupun santri Ma'had Aly memang nampak berat. Beban ini masih harus ditambah dengan beban-beban lain yang mengikat dan harus diikuti oleh santri PDF Ulya. Santri masih dibebani harus mengikuti kegiatan pembelajaran yang 
bersifat ekstra kurikuler maupun yang bersifat Jami'ah. Beban santri untuk kegiatan ekstra kurikuler antara lain; bahasa Inggris, bahasa Arab, kajian kitab, kaligrafi, seni banjari, tata busana, public speaking, dan manaqib.

Pendidikan Diniyah Fromal (PDF) Ulya Al Fithrah bagi Pondok pesantren salafiyah di lingkungan Kota Surabaya dan sekitarnya cukup dikenal, sehingga menjadi rujukan bagi pondok pesantren salafiyah yang akan menyelenggarakan PDF. Bahkan menurut Achmad Kunawi (Kepala PDF) sering dari pondok pesantren konsultasi tentang pendirian PDF daripada ke Kementerian Agama. Hal ini dimaklumi karena program PDF adalah program Pusat sehingga layanan dan informasi bahkan saat ujian nasional (Imtihan Wathani) yang berlangsung tanggal 10 - 12 Maret 2018 dan diikuti oleh 836 santri se Indonesia, terdiri dari 431 santri putra dan 405 santri putri soalnya didatangkan langsung dari pusat tanpa melalui Kanwil Kemenag.

Menurut Istono dari Kementerian Agama Kota Surabaya, bahwa penyelenggaraan PDF di ponpes salafiyah sudah lebih mulai jelas, yaitu dalam sistem keuangan Kemenag Kab/Kota sudah ada akun yang khusus untuk PDF. Oleh karena itu, apabila pondok pesantren salafiyah akan menyelenggarakan PDF tidak sulit apabila memenuhi persaratan. Hanya saja karena ini program baru dan yang pertama menyelenggarakan di kota Surabaya adalah PDF Ulya Al Afithrah, maka apabila akan menyelenggarakan PDF untuk berkonsultasi dengan pengelola PDF Al Fithrah Ponpes Assalafi Al Fithrah. 
Dalam FGD (Focus Group Discussion) di Ponpes Sunan Giri, bahwa penyelenggaraan PDF sebenarnya tidak terlalu sulit bagi pondok pesantren salafiyah. Apalagi PDF ini mememiliki orientasi membentuk kader ulama yang sudah menjadi bagian dari tugas pondok pesantren salafiyah mencetak ulama. Menurut Ismail (Pengasuh Ponpes Sunan Giri) bahwa secara teoritis penyelenggaraan PDF tidak terlalu sulit, hanya saja keterbatasan jumlah santri mukim dan model penyelenggaraan pendidikan yang sedang berjalan sudah cukup mapan, maka untuk mendirikan PDF sebag ai lembaga pendidikan diniyah formal untuk mencetak kader ulama membutuhkan pemikiran tersendiri.

\section{$\square$ PDF ULYA AL FITHRAH; LANGKAH STRATEGIS MENYELENGGARAKAN PENDIDIKAN DINIYAH FORMAL}

Pendidikan Diniyah Formal (PDF) Ulya didirikan untuk memberikan pilihan kepada masyarakat untuk mendidik para santri menjadi kader ulama sesuai dengan PMA Nomor 13 tahun 2014. PDF Ulya juga dihadirkan menjadi salah satu entitas kelembagaan pendidikan keagamaan Islam untuk menghasilkan lulusan mutafaqqih fiddin (ahli ilmu agama) guna menjawab atas langkanya kader mutafaqqih fiddin. Oleh karena itu basis kitab yang dijadikan mata pelajaran adalah kitab kuning (kutub al-turats) karya ulama salaf. 


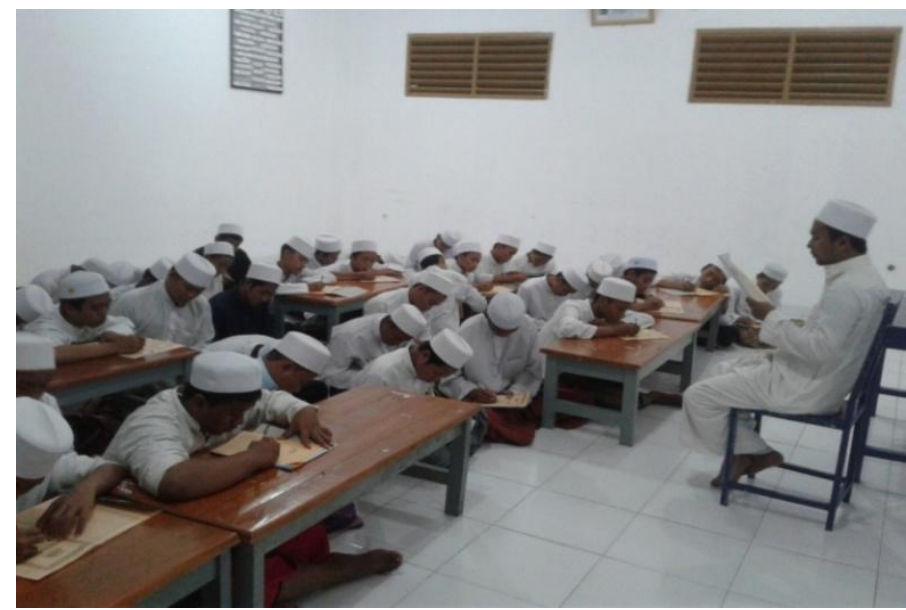

Pembelajaran kutub at-turats calon ulama tafaqquh $f i$ addin PDF Ulya Al Fithrah

PDF Ulya Fithrah adalah jawaban dari kelangkaan mutafaqqih fiddin atau paling tidak merupakan upaya yang terstruktur dan terprogram secara formal serta mengikuti regulasi dari Pemerintah (Kementerian Agama). Upaya ini bagi pondok pesantren al Fithrah adalah langkah strategis untuk mengikuti perkembangan zaman dan tuntutan masyarakat dan bangsa. Apalagi PDF ini bagi Kementerian Agama merupakan bagian implementasi dari skenario besar untuk menjadikan pendidikan di Indonesia khususnya pesantren sebagai destinasi pendidikan (Profil, 2018: 1).

Ada beberapa hal PDF Al Fithrah menyelenggarakan model pendidikan diniyah formal. Apabila dilihat dari akar sejarahnya, pondok pesantren Assalafi Al Fithrah merupakan pesnatren yang sangat adaptif dengan perkembangan 
lembaga pendidikan di Indonesia. Pada sisi yang lain, ponpes Assalafi Al Fithrah harus tetap konsisten untuk melestarikan kitab kuning sebagai sumber pembelajaran utama sekaligus cikal bakal berdirinya ponpes. Persolan inilah, Syaikh KH. Achmad Asrory Al Ishaqy selalu mensiasati agar kedua model pendidikan (pendidikan al pesantren salafiyah dan pendidikan formal) dapat terakomodasi. Apalagi tidak sedikit para santri yang menginginkan studi lanjutan ke Perguruan Tinggi.

Langkah awal yang dilakukan dalam penyelenggaraan pendidikan formal adalah penyelenggaraan program ujian paket C yang setara dengan SMA. Pada tahun 2008 keluar peraturan Dirjen Pendidikan Islam Nomor DJ I / 457 / 2008 sehingga Ponpes Assalafi Al Fithrah menyelenggarakan model Mu'addalah yang dapat menyelenggarakan ujian akhir secara mandiri. Penyelenggaraan $\mathrm{Mu}$,addalah yang setara dengan MA/SMA ini berjalan dengan baik dan berhasil meluluskan santri untuk bisa melanjutkan ke Perguruan Tinggi terutama Ma'had 'Aly dan Perguruan Tinggi Islam Swasta.

Ponpes Assalafi Al Fithrah dalam menyelenggarakan pendidikan formal terus mengikuti regulasi Pemerintah. Dari beberapa perubahan peraturan selalu diikuti dengan konsisten tanpa mengurangi dan menggeser substansi pesantren sebagai lembaga pengkaji kitab kuning. Begitu juga ketika Kementerian Agama meregulasikan pendidikan diniyah formal dengan PMA Nomor 13 tahun 2014, Ponpes 
Assalafi Al Fithrah mengikuti dengan mendirikan Pendidikan Diniyah Formal (PDF) Al Fithrah. Adapun langkah awal adalah dengan menyelenggarakan PDF tingkat atas (Ulya) pada tahun 2014 meskipunpada saat itu PMA baru disahkan.

Pada awal penyelenggaraan PDF Ulya dan sampai meluluskan tahun pertama berjalan masih mengadakan pembenahan agar sesuai dengan standar nasional pendidikan. Menurut Achmad Kunawi bahwa petunjuk teknis (juknis) yang bersifat operasional dari Kementerian Agama masih sangat dibutuhkan agar penyelenggaraan sesuai dengan standar pendidkan nasional. Standar Nasional Pendidikan terdiri dari :

\section{STANDAR KOMPETENSI LULUSAN}

Standar Kompetensi Lulusan (SKL) pendidikan keagamaan Islam PDF Ulya Al Fithrah merupakan jaminan mutu atau kualitas lulusan dengan kondisi ideal. SKL pada PDF Ulya terbagi dalam mata pelajaran lokal dan mata pelajaran yang masuk dalam struktur kurikulum (kurikulum Inti). SKL tersebut dan tantangannya adalah sebagai berikut.

a. Hafalan Juz 1 dan juz 30 serta surat al ma'tsurat (Yasin, Waqiah, Al Mulk, dan As Sajadah) belum menetapkan SKL, sehingga tantangan ke depan Hafalan Juz 1 dan juz 30 serta surat al ma'tsurat (Yasin, Waqiah, Al Mulk, dan As Sajadah) menjadi SKL setelah santri menyelesaikan studi di PDF. 
b. Hafalan Aurad yang dituntunkan Hadrotusy Syaikh KH. Achmad Asrory Al Ishaqy belum memiliki SKL yang ditetapkan secara ideal sehingga ke depan hafalan Aurad menjadi SKL dalam kurikulum

c. Mampu membaca dan memahami kitab at turats (kifayatul akhyar) belum semua santri alumni PDF mampu membaca dan memahami kitab kuning (kitab at turats) tersebut, sehingga tantang kedepan adalah menetapkan SKL untuk membaca dan memahami kitab at turats (kifayatul akhya atau minhaji).

d. Untuk mata pelajaran umum SKL mengikuti ketetapan yang sudah ada

\section{STANDAR ISI}

Standar isi kurikulum PDF Ulya Al Fithrah secara ideal harus dimiliki pada setiap mata pelajaran yang menjadi beban belajar santri. Namun demikian masih terdapat beberapa mata pelajaran atau yang menjadi beban belajar santri. Hal ini dapat dilihat pada standar isi kurikulum di bawah ini

a. Hafalan Juz 1 dan juz 30 serta surat al ma'tsurat (Yasin, Waqiah, Al Mulk, dan As Sajadah) belum memiliki kurikulum hafalan yang khusus sebagaimana buku paket. Tantangan ke depan PDF Ulya Al Fithrah harus membuat Standar Isi untuk mempermudah santri untuk menghafal. 
b. Hafalan Aurad yang dituntunkan Hadrotusy Syaikh KH. Achmad Asrory Al Ishaqy belum memiliki Standar Isi kurikulum yang lengkap. Tantangan ke depan harus disusun standar isi menjadi kurikulum hafalan khusus Aurad

c. Mampu membaca dan memahami kitab at turats (kifayatul akhyar) belum secara tegas dan terstruktur sebagai standar Isi kurikulum. Hal ini dikarenakan standar yang dilakukan adalah santri menyelesaikan seluruh kitab yang menjadi beban belajar tanpa dipilah-pilah untuk kepentingan ujian nasional. Tantangan ke depan PDF Ulya Al Fithrah harus menyusun standar isi sesuai dengan standar isi yang disepakati secara nasional. Persoalannya adalah secara nasional belum ada Juknis dan juklak terkait dengan beban belajar kitab at turats agar santri membaca dan memahami kitab at turats (kifayatul akhya atau minhaji).

d. Standar isi untuk mata pelajaran umum mengikuti ketetapan yang sudah ada

\section{STANDAR PROSES}

Standar proses dalam pembelajaran PDF Ulya Al Fithrah memiliki keunikan tersendiri dibandingkan sekolah formal pada umumnya. Standar proses terbagi menjadi dua meskipun tetap sama dalam kelas (klasikal). Strategi pembelajaran di pesantren dikenal dengan adanya model 
halaqah $^{8}$ sedangkan di sekolah tidak dilakukan. Standar proses dalam pembelajaran yang dilakukan di PDF Ulya Al Fithrah adalah sebagai berikut.

a. Pada mata pelajaran Hafalan Juz 1 dan juz 30 serta surat al ma'tsurat (Yasin, Waqiah, Al Mulk, dan As Sajadah) proses pembelajaran masih individual dan sistim setor meskipun berada dalam satu ruangan atau satu halaqah. Tantangan ke depan adalah membentuk halaqah membaca dan hafalan al-Qur'an teman sebaya atau sekelas.

b. Pada Hafalan Aurad yang dituntunkan Hadrotusy Syaikh KH. Achmad Asrory Al Ishaqy dilakukan secara bersama-sama dan tidak semua santri membawa buku Aurad. Tantangan ke depan adalah $100 \%$ santri harsu membawa buku Aurad

c. Proses pembelajaran berkaitan dengan membaca dan memahami kitab at turats (kifayatul akhyar) dilakukan dengan metode pengajar memaknai kitab dan menjelaskannya dan pengajar membagi santri untuk praktek membaca kitab. Proses pembelajaran ini sudah berjalan sesuai dengan kebiasaan pondok pesantren Assalafi sebelum menyelenggarakan PDF.

${ }^{8}$ Proses pembelajaran sistim halaqah adalah model pembelajaran dalam satu kelas (biasanya di masjid) dengan posisi para santri duduk membuat setengah lingkaran menghadap ustadz (guru). Proses pembelajaran ini biasanya digunakan untuk pembelajaran model bandongan (bersama-sama dalam satu materi/kitab. Lawanya bandongan adalah sorogan dimana pembelajaran santri maju satu persatu menghadap Kyai) 
d. Strategi untuk mata pelajaran umum mengikuti ketetapan yang sudah ada

\section{STANDAR PENDIDIKAN DAN TENAGA KEPENDIDIKAN}

Standar pendidikan dan tenaga kependidikan pada PDF Ulya Al Fithrah tidak secera keseluruhan dalam kondisi ideal terutama untuk mata pelajaran pendidikan umum. Untuk mata pelajaran yang bersumber pada kitab at turats (kitab kuning) secara kompetensi dan profesionalitas sudah sesuai karena semua pengajar memiliki kemampuan dan sudah profesional dalam penguasaan kitab yang diajarkan. Akan tetapi untuk meta pelajaran umum dan tenaga kependidikan masih terdapat kondisi kurang ideal.

Dilihat dari tingkat pendidikan masih terdapat tenaga pendidik dan wali kelas yang belum selesai menyelesaikan pendidikan Sarjana S.1.. Begitu juga kompetensi pemangku mata pelajaran umum masih terjadi missmacth dimana Sarjana S.1. jurusan Tafsir/Hadits mengajar Matematika.

\section{STANDAR SARANA DAN PRASARANA}

Standar sarana dan prasarana PDF Ulya Al Fithrah belum secara keseluruahn dapat terpenuhi. Sarana yang bersifat substantif mata pelajaran secara umum telah terpenuhi karena seluruh santri memiliki kitab-kitab at turats dan buku-buku mata pelajaran umum. Namun demikian standar sarana dan prasarana pembelajaran yang ideal dalam beberapa hal belum terpenuhi, seperti 
a. sarana pembelajaran kelas masih sangat terbatas seperti meja belajar tidak sesuai dengan kebutuhan santri, jumlah santri dalam satu kelas lebih dari 32 santri sebagai kondisi ideal, tidak terdapat alat audio visual (multi media) untuk pembelajaran yang membutuhkan penjelasan secara audio visual, dan tidak terdapat almari kelas.

b. Perpustakaan dengan ruangan yang kurang memadai dibanding dengan rasio santri yang cukup banyak.

c. Belum ada ruang khusus komputer yang memadai. Menurut Hermansyah dalam waktu dekat ini santri dapat menggunakan komputer karena sudah terdapat penambahan komputer.

d. Ruang pimpinan (Kepala PDF), tenaga pendidik guru BK, dan staf tata usaha berada dalam satu ruangan dan hanya dibatasi papan, sehingga masih sempit.

e. Belum terdapat ruang rapat khusus, sehingga ketika rapat menggunakan ruang "bersama" tersebut dengan posisi seadanya tempat duduk.

f. Tempat ibadah tersedia dan mampu untuk praktek atau salat berjamaah santri.

g. Terdapat UKS yang tergabung dalam UKS Pesantren.

h. Terdapat tempat bermain dan olahrag yang cukup luas sehingga santri dapat memilih tempat untuk belajar di luar kelas. 


\section{STANDAR PENGELOLAAN}

Standar pengelolaan PDF Ulya Al Fithrah dapat dilihat dalam berbagai aspek, yaitu

a. Perencanaan program dari penyusunan visi, misi, tujuan, rencana kerja, pelaksanaan rencana kerja (pedoman PDF, Struktur organisasi PDF, pelaksanaan skegiatan sekolah), penciptaan suasana/kultur sekolah, melibatkan peran serta masyarakat telah disusun secara lengkap sesuai dengan standar yang ditetapkan oleh BSNP.

b. Pengawasan dilakukan oleh sekolah dengan selalu mengadakan pengawasan, supervisi, evaluasi, dan pelaporan dilakukan secara rutin dan dilaporkan ke Kementerian Agama sebagai Pembinan PDF.

c. Kepemimpinan PDF telah berjalan sesuai dengan aturan. Bahkan karena PDF berada dibawah Ponpes, maka kepemimpinan lebih lengkap, yaitu Kepala ponodk, Kabag. Pendidikan, Kepala sekolah, wakil Kepala bidang kurikulum, wakil kepala bidang kesiswaan $\mathrm{Pa} / \mathrm{Pi}$, Wakil kepala bidang kesiswaan $\mathrm{Pa} / \mathrm{Pi}, \mathrm{BK} \mathrm{Pa} / \mathrm{Pi}$, Bidang Sarpras, Staf TU, dan Staf Perpustakaan. Diantara kepemimpinan sekolah juga terdapat kepemimpian siswa yaitu OSIS PDF Ulya Al Fithrah. 


\section{STANDAR PEMBIAYAAN PENDIDIKAN}

Standar pembiayaan pendidikan di PDF Ulya AL Fithrah tidak lepas dari standar pembiayaan pondok pesantren. Standar pembiyaan ini merupakan biaya investasi, biaya operasi dan biaya personal. Biaya khusus sebagai santri mukim untuk penerimaan santri baru tahun 2018 adalah biaya pendaftaran (100.000), mengganti biaya tempat pakaian (400.000), mengganti biaya alas tidur (150.000), dan amal jariyah pembangunan sebagai investasi (1.750.000).

Biaya operasional bulanan terbagi menjadi syahriyah pondok yang berupa syhariyah SPP (190.000), air bersih (16.000), listrik (24.000), perawatan sarana (24.000), kesehatan (21.000), kesejretarian (12.000), kewadhifahan (30.000). Biaya syahriyah makan berupa makan (306.000), air minum sehat (35.000), buah-buahan (35.000), dan susu sapi murni (18.000), donatur (4.000), Haul akbar (10.000), dan khidmah manaqib (3.000). Disamping biaya investasi dan biaya operasional personal pendidikan yang berasal dari santri, pembiayaan juga diperoleh dari dana BOS Madrasah/ BOPDA.

Untuk gaji guru, yayasan telah menetapkan dengan menggunakan sistem jam mengajar, yaitu dalam 1 jam pembelajaran menerima gaji Rp. 11.000,-. Dari rata-rata guru mengajar paling sedikit 12 jam sampai dengan 40 jam mengajar. Menurut Kepala PDF Ulya bahwa guru yang mengajar 12 jam atau lebih sedikit adalah guru mata 
pelajaran umum karena guru tersebut juga mengajar di sekolah lain, sedangkan guru yang mengajar pendidikan keagamaan Islam mengajar maksimal 40 jam dan apabila guru yang mengajar melebih dari 40 jam maka kelebihannya adalah shodaqah mengajar.

\section{STANDAR PENILAIAN PENDIDIKAN}

Standar penilaian pendidikan PDF Ulya Al Fithrah dirumuskan mengacu pada standar penilaian pada pendidikan sekolah formal lainya, yaitu penilaian sikap, pengetahuan, dan keterampilan. Adapun standar penilaian pada mata pelajaran yang menjadi beban belajar santri adalah sebagai berikut

a. Standar penilaian pada mata pelajaran Hafalan Juz 1 dan juz 30 serta surat al ma'tsurat (Yasin, Waqiah, Al Mulk, dan As Sajadah) mencakup makhoorijul huruf, tajwid, dan kelancaran.

Namun demikian secara teknis belum ada juknis sehingga masih perlu dirumuskan junknis standar penilaian baik sikap, pengetahuan, maupun keterampilan.

b. Standar penilaian pada Hafalan Aurad yang dituntunkan Hadrotusy Syaikh KH. Achmad Asrory Al Ishaqy mencakup makhoorijul huruf, tajwid, dan kelancaran. Namun demikian secara teknis belum ada juknis sehingga masih perlu dirumuskan junknis standar penilaian baik sikap, pengetahuan, maupun keterampilan 
c. Standar penilaian pada kitab at turats (kifayatul akhyar) dan kitab lainnya adalah pemahaman makna, kelancaran baca, murod, dan penguasaan nahwu/sharf. Standar ini belum lengkap dan masih dalam proses penyusunan. Namun demikian secara kualitas dapat dilihat dari teknik penilaian menggunakan teknik praktek membaca dan menjelaskan. Selain ujian model lisan diatas juga dilakukan ujian atau tes ulangan sebagaimana sekolah umum, yaitu ulangan harian, mid semester, dan semester, serta penugasan. Dalam ulangan ini semua soal ujian menggunakan bahasa Arab tanpa haraqat/sakl.

d. Standar penilaian mata pelajaran umum mengikuti ketetapan yang sudah ada, yaitu menggunakan sistem ulangan harian, mid semester, penugasan, dan/atau bentuk lain yang diperlukan, dan semesteran.

e. Penilaian hasil belajar oleh satuan pendidikan dilakukan dalam bentuk ujian Madrasah Aliyah pada mata pelajaran umum, sedangkan untuk mata pelajaran keagamaan Islam ujian nasional menggunakan kalender Hijriyah. Istilah ujian nasional pada PDF adalah Imtihan Wathoniyah. Selain ujian nasional untuk tingkat kelulusan PDF Ulya adalah ujian akhir penguasaan kitab Fathul Muin'.

${ }^{9}$ Ada 2 jenis ujian akhir di PDF Ulya Al Fithrah untuk mata pelajaran kutub at-turats (kitab kuning) yang kemungkinan tidak dilakukan oleh 
$\square$ PDF ULYA AL FITHRAH; MEMBENTUK KADERISASI ULAMA TOLERAN

Sebagaimana penjelasan di atas bahwa PDF Ulya Al Fithrah merupakan bagian dari pendidikan yang dikembangkan oleh Ponpes Assalafi Al Fithrah. Oleh karena itu, goal oriented yang akan dicapai adalah terbentuknya kader ulama sesuai dengan ulama salafushsholih. Pembentukan kader ulama ini dapat terlihat dari kurikulum pendidikan keagamaan Islam yang bersumber dari kitab kuning (kutub atturats) dan model pembelajaran yang menggunakan sistem kajian kitab secara bandongan (klasikal sebagaimana pendidikan formal) dan secara sorogan untuk mengetahui penguasaan kitab secara individual.

PDF Ulya yang lain. Kedua jenis ujian tersebut adalah 1) ujian kenaikan kelas dimana santri maju satu persatu dan diuji oleh 2 orang ustadz.untuk membacakan kitab, menerjamahkan, menyampaikan isi, dan pertanyaan lain dari penguji. 2) Ujian akhir setelah Imtihan Wathaniyah (ujian nasional). Ujian kelulusan ini bisa ditunda selama santri siap akan tetapi belum bisa mengambil ijazah selama belum mengikuti ujian akhir. Dalam ujian ini kitab yang harus dikuasai adalah kitab Fathul Mu'in dan ketika ujian santri didampingi kedua orang tua berhadapan dengan 3 orang penguji. Bahkan dalam perencanaan berikutnya adalah ujian publik di Masjid dengan model yang sama akan tetapi dihadapan jamaah. 


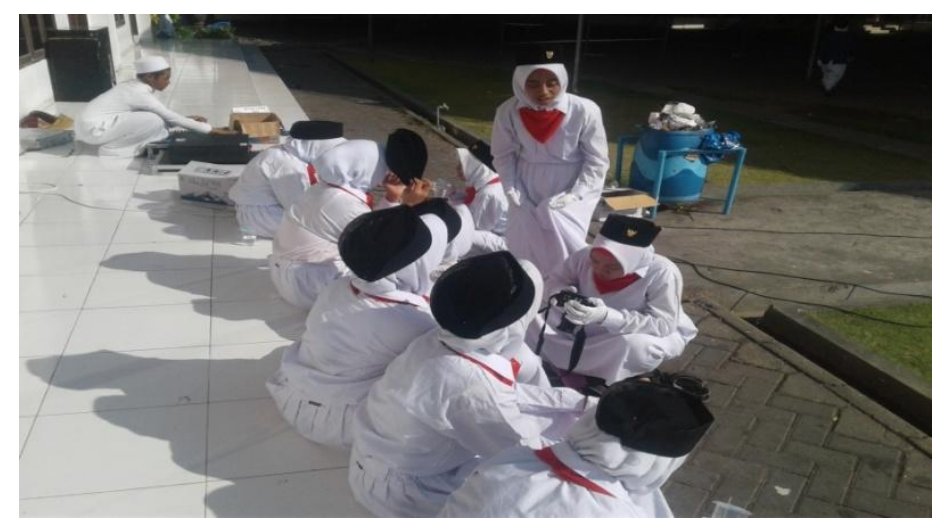

Upacara bendera setiap hari senin PDF Ulya Al Fithrah (Salah satu pembentuk ulama toleran dan nasionalis)

PDF Ulya Al Fithrah dalam mengkader peserta didik sebagai kader ulama memiliki dua kekhasan, yaitu kekhasan ponpes Assalafi sebagai pondok salafiyah dan kekhasan pondok pesantren sebagai pondok yang sarat dengan thariqah. Dari kedua kekhasan tersebut dibingkai dalam frame nasionalisme yaitu dengan model pendidikan formal yang tidak dapat dilepaskan dari pendidikan umum. Ddisinilah PDF Ulya Al Fithrah diharapkan dapat membentuk kader ulama yang memiliki tingkat toleransi dalam berbagai aspek.

Pembentukan kader ulama yang memiliki sikap toleran melalui proses pendidikan di PDF Ulya Al Fithrah telah digariskan dalam misi PDF Ulya Al Fithrah yaitu memiliki sikap toleransi dan solidaritas. Hal ini ditunjukan dengan adanya hari libur mingguan pada hari ahad, libur mengikuti 
hari libur dalam kalender nasional meskipun hari natal dan hari-hari besar agama lainnya, Adanya upacara bendera setiap hari senin dengan kelompok paduan suara menggunakan seragam putih-putih berdasi (Hassduk) merah putih, upacara wajib setiap tanggal 17 Agustus, dan upacara hari santri nasional setiap tanggal 22 oktober.

Pembentukan sikap toleran juga dapat dilihat dari kurikulum kitab kuning yang diajarkan. Dalam pengajaran kitab kuning sebagai mata pelajaran didalamnya terdapat muatan-muatan yang mengarahkan pada pembentukan sikap toleransi, seperti pada :

1. Kompetensi Inti - 1 (KI-1) untuk kompetensi inti sikap spiritual memuat materi tentang menghayati dan mengamalkan perilaku jujur, disiplin, tanggunjawab, peduli (gotong royong, kerjasama, toleran, damai), santun, responsif dan pro aktif menunjukan sikap sebagai bagian dari solusi atas berbagai permasalahan

2. Pada mata pelajaran Al-Qur'an terdapat tujuan yang ingin dicapai yaitu memperoleh bekal pengetahuan dan keterampilan membaca, menulis, menghafal dan mengartikan juz Amma dan surah-surah pilihan sebagai bekal dalam kehidupan bermasyarakat, berbangsa dan bernegara

3. Pada mata pelajaran Tauhid terdapat tujuan pembelajaran yaitu memotivasi peserta didik untuk mempelajari dan mempraktekan ajaran akidah Islam yang inklusif dalam bentuk pembiasaan perilaku kehidupan sehari-hari. 
4. Pada mata pelajaran Ilmu Kalam terdapat tujuan pembelajaran yaitu santri memiliki sikap keberagamaan atau keberimanan yang berakidah kalam ahlussunnah waljamaah yang moderat dan penuh kasih sayang (rahmah), menjadi cendekiawan atau ulama yang penuh tanggungjawab dan bijaksana dalam kehidupan pribadi, bermasyarakat, berbangsa, dan bernegara, memupuk diri sebagai muslim Indonesia yang beriman dan bertaqwa kepada Allah SWT dengan sikap penuh dengan rendah hati, tidak memiliki sikap klaim diri sebagai muslim yang benar, dan Mewujudkan diri sebagai muslim Indonesia yang berakidah ahlisunnah waljamaah dan berakhlak mulia dengan penuh kecintaan terhadap tanah air dan NKRI.

\section{$\square$ PENDIDIKAN DINIYAH FORMAL MENYONGSONG MASA DEPAN BANGSA}

Penyelenggaraan Pendidikan Diniyah Formal (PDF) telah berjalan selama 4 tahun dan telah berhasil meluluskan santri PDF angkatan pertama tahun 2018. Menurut Achmad Kunawi (Kepala PDF Ulya Al Fithrah), bahwa lulusan pertama ini masih prematur sehingga masih banyak yang harus dibenahi terutama untuk ijazah yang belum keluar. Hal ini bukan merupakan aspek penghambat karena ujian dapat berjalan dengan lancar karena soal langsung dikirim dari Jakarta sehingga tidak akan pernah mengalami kebocoran soal. 
Perjalanan PDF yang masih baru sudah nampak responsibility dari pondok pesantren salafiyah dan masyarakat luas. Respons tersebut nampak dari beberapa ponpes salafiyah yang melakukan studi banding ke PDF Ulya Al Fithrah dan setiap tahun selalu terjadi penambahan santri PDF terutama pada level isti'dad. Respons tersebut didorong karena kebutuhan santri untuk melanjutkan studi lanjut ke jenjang yang lebih tinggi dan kemampuan pondok pesantren untuk menyelenggarakan pendidikan formal akan tetapi tetap mempertahankan tradisi penguasaan kitab kuning agar menjadi generasi tafaqquh fi addin.

Jalan keluar Kementerian Agama RI dengan menyusun regulasi melalui PMA Nomor 13 tahun 2014 menjadi barometer sekaligus harapan bangsa Indonesia ke depan. Dari aspek implementasi Pendidikan Diniyah Formal di pondok pesantren salafiyah dapat dilakukan sesuai dengan standar nasional sekolah. Dengan demikian, harapan bangsa Indonesia memiliki SDM yang berkualitas dan berkarakter Keislaman dan ke Indonesiaan dapat terpenuhi. Sementari itu, dari aspek pondok pesantren salafiyah sebagai pusat perkaderan ulama penerus ulama salafussholih juga dapat dilakukan. Hal ini dikarenakan kurikulum pendidikan keagamaan Islam yang diberikan kepada santri sebagai peserta didik bersumber dari kitab kuning (kutub at-turats) karya ulama salaf. Bahkan harapan terbentuknya kader ulama yang memiliki toleransi dapat terwujud karena kitabkitab yang dijadikan rujukan juga mengedepankan 
demokrasi dan diperkuat dengan pemberian mata pelajaran umum.

Respons pondok pesantren terhadap pendirian Pendidikan Diniyah Formal (PDF) pada akhirnya terjadi keterbukaan bagi pondok pesantren salafiyah yang cenderung eksklusive. Adaptifitas pondok pesantren salafiyah dalam dunia pendidikan dan akomodirnya Kementerian Agama dalam menjawab keinginan Pondok pesantren menjadi sangat sinkron. Ada beberapa hal yang menjadi ketertarikan terhadap munculnya PDF di pondok pesantren salafiyah, yaitu;

1. Kemudahan penyelenggaraan PDF secara umum karena program baru dan Ponpes Assalafi Al Fithrah sudah siap dalam berbagai aspek seperti kesiapan SDM, santri, dan fasilitas pembelajaran meskipun kesiapan tersebut belum maksimal akan tetapi secara operasional dan persaratan pendirian sudah memenuhi sarat

2. Kementerian Agama baik Pusat maupun Kanwil dan Kabupaten/Kota Surabaya sangat mendukung dan selalu mengadakah koordinasi sehingga beberapa konsekuensi penyelenggaraan segera dipenuhi untuk mencapai target

3. Mengingat program PDF masih baru dan masih sedikit (Kota Surabaya baru ada 1 PDF) maka koordinasi antar PDF se Indonesia tidak kesulitan. Bahkan menurut Achmad Kunawi, selama ini ada kemudahan untuk mendiskusikan dengan Kemenag 
RI untuk menguatkan PDF, baik dari aspek SDM, penguatan kurikulum, maupun sosialisasi. Dalam koordinasi ini selalu difasilitas oleh Kementerian Agama RI.

4. Adanya optimisme dari santri PDF dan alumni PDF 'Ulya, karena lebih prospektif untuk memadukan antara Ilmu (Agama dan Umum), Iman, dan Amal serta memiliki karakter berakhlakul karimah yang siap memimpin bangsa ini. Optimisme ini didorong oleh keberhasilan alumni diterima di berbagai Perguruan Tinggi Negeri maupun Swasta meskipun melalui "negosiasi" karena beberapa Perguruan Tinggi dan instansi Pemerintah lain yang belum mengerti dan memahami PDF adalah sekolah formal.

5. Optimisme PDF juga karena didorong oleh Kemenag Kabupaten/Kota yang sudah memiliki Akun/Rumah PDF sehingga kemungkinan penganggaran untuk peningkatan kualitas fisik dan pembelajaran akan segera terwujud.

6. Sudah teranggarkanya dana BOS untuk PDF Ulya AL Fithrah dan setiap tahun ada kenaikan anggaran

Meskipun penyelenggaraan PDF Ulya Al Fithrah dapat berjalan lancar yaitu dari proses awal berdiri, proses penyelenggaraan sampai berhasil mengikuti ujian nasional, akan tetapi ada beberapa hal yang menjadi penghambat seperti :

1. Belum terumuskannya juknis dalam mata pelajaran pendidikan keagamaan Islam sehingga terdapat 
kemungkinan ada perbedaan masing-masing PDF di pondok pesantren salafiyah, apalagi setiap pesantren salafiyah memiliki kekhasan. Sementara itu, ujian nasional PDF dibutuhkan standarisasi kurikulum lengkap dengan juklak dan junis bukan sekedar kitab yang harus diajarkan.

2. Dengan belum terumuskannya Juknis bahan ajar Pendidikan keagamaan Islam, maka PDF Ulya Al Fithrah masih belum menyusun RPP sebagaimana dalam mata pelajaran umum

3. Fasilitas pembelajaran masih menggunakan fasilitas pondok pesantren sehingga masih terbatas terutama untuk pembelajaran mata pelajaran umum. Efek dari kurangnya fasilitas ini pembelajaran mata pelajaran umum kurang optimal terutama berkaitan dengan pembelajaran yang membutuhkan audio visual.

4. Tenaga Pendidik dan Kependidikan yang kompeten dan professional masih seadanya. Tenaga Pendidik rata-rata sudah sarjana S.1. dan S.2, hanya saja masih terdapat missmatch, seperti masih terdapatnya S.1 jurusan Ilmu tafsir akan tetapi mengajar matematika.

5. Meskipun Asosiasi PDF Se Indonesia sudah ada akan tetapi belum berjalan optimal sebagai Persatuan Guru Republik Indonesia (PGRI). Padahal Asosiasi ini menjadi sangat penting sebagai jembatan pengelola PDF melakukan sinkronisasi program

6. Dengan lambatnya ijazah PDF setelah ujian nasional, maka santri masih kebingungan terutama yang diterima di Perguruan Tinggi umum. 
7. Belum semua Perguruan Tinggi mengetahui di Pondok pesantren Salafiyah sudah memiliki PDF sehingga terdapat santri yang ditolak mendaftar karena syarat keterangan yang ada masih dipertanyakan.

8. Regulasi dari Kementerian Agama RI tidak teredukasi dengan baik ke Kementerian Agama Wilayah maupun Kabupaten/Kota, sehingga banyak pondok pesantren salafiyah masih bingung cara menyelenggarakan Pendidikan Diniyah Formal (PDF). Apalagi di Kemenag Kab/Kota tidak ada bagian khusus yang menangani tentang PDF. 


\section{BAB V \\ PENUTUP}

1. Penyelenggaraan Pendidikan Diniyah Formal (PDF) merupakan prgram Kementerian Agama yang secara substansi diapresiasi oleh pondok pesantren salafiyah. PDF dapat dikatakan menjadi jawaban yang selama ini alumni pondok pesantren salafiyah merasa dianak tirikan. Padahal dalam konteks kelembagaan pendidikan, pondok pesantren lebih memiliki pengalaman yang luas dibandingkan dengan sekolah formal pada umumnya dalam mengelola peserta didik (santri) dalam bingkai kelembagaan pendidikan. Dibukanya kran Pondok pesantren salafiyah menyelenggarakan pendidikan formal ternyata memiliki kemampuan yang dapat dipertanggungjawabkan dalam pengelolaan. Fakta bahwa PDF Ulya Al Fihtrah yang berada dibawah naungan pondok pesantren Assalafi Al Fithrah kedinding Kota Surabaya mampu mengimplementasikan Pendidikan Formal berbasis pondok pesantren salafiyah. Dari 
aspek 8 standar Pendidikan Nasional semua dapat terpenuhi, yaitu

a. Standar Kompetensi Lulusan pendidikan keagamaan Islam PDF Ulya Al Fithrah merupakan jaminan mutu atau kualitas lulusan dengan kondisi ideal, seperti hafal Juz 1 dan juz 30 serta surat al ma'tsurat (Yasin, Waqiah, Al Mulk, dan As Sajadah), hafalan Aurad, mampu membaca dan memahami kitab at turats (kifayatul akhyar), dan untuk mata pelajaran umum berhasil SKL yang sudah ada

b. Standar isi kurikulum PDF Ulya Al Fithrah bersumber dari itab kuning (kutub at-turats), meskipun masih perlu pembenahan terutama dalam menyusun struktur sebagai standar Isi kurikulum. Adapun standar isi untuk mata pelajaran umum mengikuti ketetapan yang sudah ada dan dapat berjalan sesuai perencanaan

c. Standar proses dalam pembelajaran PDF Ulya Al Fithrah memiliki keunikan tersendiri terutama ketika pembelajaran dalam kelas, yaitu tidak hanya model ceramah dengan guru berdiri di depan, akan tetapi juga menggunakan model halaqah.

d. Standar pendidikan dan tenaga kependidikan pada PDF Ulya Al Fithrah telah melalui proses rekrutmen agar profesional dan kompeten. Paling tidak tenaga pendidik minimal S.1 dan banyak yang sudah S.2.

e. Standar sarana dan prasarana PDF Ulya Al Fithrah yang terus diadakan pembenahan agar 
memenuhi standar untuk PBM. Misalkan dari jumlah rata-rata siswa dalam satu kelas terlalu banyak dan tidak ada sarana audio visual untuk pembelajaran di kelas, serta perpustakaan dengan ruangan yang kurang memadai dibanding dengan rasio santri yang cukup banyak.

f. Standar pengelolaan PDF Ulya Al Fithrah sudah dimulai dari Perencanaan program, Pengawasan, supervisi, evaluasi, dan pelaporan yang dilakukan secara rutin dan dilaporkan ke Kementerian Agama sebagai Pembinan PDF. Disamping itu adanya kepemimpinan PDF telah berjalan sesuai dengan aturan dimana menjabat paling lama 2 kali jabatan secara berturut turut.

g. Standar pembiayaan pendidikan di PDF Ulya Al Fithrah telah tersusun dari biaya investasi, biaya operasional dan biaya personal. Sumber pembiayaan berasal dari BOS/BOPDA, dan santri

h. Standar penilaian pendidikan PDF Ulya Al Fithrah telah mengacu pada standar penilaian pada pendidikan sekolah formal lainya, yaitu penilaian sikap, pengetahuan, dan keterampilan. Bahkan standar penilaian pada kitab at turats (kifayatul akhyar) dan kitab lainnya adalah pemahaman makna, kelancaran baca, murod, dan penguasaan nahwu/sharf. Adapun penilaian hasil belajar akhir adalah ujian nasional atau Imtihan Wathoniyah dan ujian akhir penguasaan kitab Fathul Muin.

2. Penyelenggaraan PDF Ulya Al Fihtrah di Pondok pesantren Assalafi tidak mengurangi orientasi pondok pesantren salafiyah sebagai pusat kaderisasi ulama tafaqquh fi addiin, Bahkan dalam konteks 
kaderisasi ulama toleran dapat dijadikan barometer lembaga pendidikan yang diselenggarakan oleh PDF Ulya Al Fithrah, karena dilihat dari substansi, baik yang bersumber pada kutb at-turats maupun dari mata pelajaran umum didalamnya memuat tentang demokrasi dan toleransi.

3. Meskipun penyelenggaran PDF Ulya Al Fithrah secara khusus baik dan sesuai dengan standar nasional pendidikan dan orientasi sebagai lembaga pendidikan pencetak kader ulama yang toleran dapat tercapai, akan tetapi masih perlu diperhatikan dalam beberapa faktor yang antara lain;

a. perlu sosialisasi dari Kementerian Agama RI terhadap seluruh stakeholder agar semua instansi yang terkait mengakui dan merespon bahwa PDF sejajar dengan SMA/MA,

b. tenaga pendidik dan kependidikan PDF perlu diberi hak yang sama untuk mengikuti Diklat yang diselenggarakan oleh Diklat Balai Diklat Kemenag RI,

c. perlu diadakan Kerjasama dengan Perguruan Tinggi Negeri dibawah Kementerian Agama, Kemendagri, dan Kemendiknas. Bahkan apabila perlu ada SKB 3 Menteri yang mengatur penyelenggaraan PDF disejajarkan dengan sekolah menengah, dan

d. Kemenag harus benar benar ready dalam penyelenggaraan PDF sehingga perlu ada Devisi khusus yang mengurusi PDF dengan perlakukan sama seperti PENMA, dan bidang/Kasi yang lain di Kemenag, sehingga ada Kepala Seksi PDF di seluruh Kemenag. 


\section{DAFTAR PUSTAKA}

A. Malik Madany. 1989. Posisi Kitab Kuning dalam Khazanah Keilmuan dalam Pesantren No.1/Vol. VI. Jakarta: P3M.

A. Mukti Ali. 1987. Meninjau Kembali Pesantren sebagai Lembaga Pendidikan Ulama dalam Pesantren No.2 Vol. IV. Jakarta: P3M.

Abdul Aziz. 1996. Tantangan Kependidikan Pesantren; Studi Kasuspengembangan SDM di dua pesantren di Demak dalam Jurnal Penelitian Agama dan Masyarakat Penamas No.22 Th.VIII. Jakarta: Balai Penelitian Agama dan Keasyarakatan.

Ahmad Syafi'i. 1996. Pesantren dan Pengembangan Sumber Daya Manusia; Studi Kasus Dari Sembilan Pesantren dalam Jurnal Penelitian Agama dan Masyarakat Penamas No.22 Th.VIII. Jakarta: Balai Penelitian Agama dan Keasyarakatan.

Ali Yafie. 1989. Kitab Kuning, Produk Peradaban Islam dalam Pesantren No.1 Vol. VI. Jakarta: P3M.

Alwasilah, A. C. (2009, April 28-May 2). The Madrasah and Chinese education in Indonesia: A comparative study. Paper presented at the International Seminar on Islamic Culture and Education in China, Hongkong. Retrieved December 30, 2013, from http://inggris.upi.edu/wp-content/uploads/2010/ 10/The-Madrasah-and-Chinese-Education-inIndonesia.pdf 
Azra, A., \&Afrianty, D. (2005, May 6-7). Pesantren and madrasa: Modernization of Indonesian Muslim society. Paper presented at the Workshop on Madrasa, Modernity and Islamic Education, Boston University, Boston, MA.Steenbrink, K. A. (1974). Pesantren, Madrasah, Sekolah: Pendidikan Islam dalamKurun Modern. Jakarta, ID: LP3ES.

El-Saha, M. I. (2008). Dinamika Madrasah di Indonesia: Menelusuri Akar Sejarah Pendidikan. Jakarta, ID: Transwacana.

Ibnu Hajar. 2009. Kiai di Tengah Pusaran Politik antara Petaka dan Kuasa. Jogyakarta: IRCiSoD.

Imam Tholkhah. 1989. Profil Lembaga Pendidikan Penyiaoan Ulama dalam Pesantren No.1/Vol. VI. Jakarta: P3M.

Karel A. Steenbrink. 1986. Pesantren Madrasah Sekolah; Pendidikan Islam dalam Kurun Modern. Jakarta: Dharma Aksara Pekasa.

Kelabora, L. (1976). Religious instruction policy in Indonesia. Asian Survey, 16(3), 230-248.

M. Dawam Rahardjo. 1974. Dunia Pesantren dalam Peta Pembaharuan dalam Pesantren dan Pembaharuan (Ed. M. Dawam Rahardjo). Jakarta: LP3ES.

M. Dawam Rahardjo. 1985. Pergulatan Dunia Pesantren; Membangun dari Bawah. Jakarta: P3M.

Martin Van Bruinessen. 1989. Kitab Fiqh di Pesantren Indonesia dan Malaysia dalam Pesantren No.1 Vol. VI. Jakarta: P3M.

Moeslim Abdurrahman. 1995. Islam Transformatif. Jakarta: Pustaka Firdaus. 
Mohammad Achyat Ahmad.1434H.,Liberalisasi Islam. Sidogiri. Pustaka Sidogiri Pondok Pesantren Sidogiri.

Muhammad Tholhah Hasan. 1989. Metode Pengkajian di Pesantren: Tinjauan Ulang dalam Pesantren No.1/Vol. VI. Jakarta: P3M.

Muhtada, D. (2014). The Mechanisms of Policy Diffusion: A Comparative Study of Shari'a Regulations in Indonesia. PhD Dissertation, Northern Illinois University.

Nurcholis Madjid.1997.Bilik-bilik Pesantren;Sebuah Potret Perjalanan. Dian Rakyat. Jakarta.

Ramayulis (2011). Sejarah Pendidikan Islam: Napaktilas Perubahan Konsep, Filsafat, dan Metodologi Pendidikan Islam dari Era Nabi SAW sampai Ulama Nusantara. Jakarta, ID: KalamMulia.

Sambutan Drs. Abdul Wahid Thahir, M.Ag. (Ka. Kemenag Kabupaten Luwu Timur) dalam acara pembukaan MQK (Musabaqah Qiraatil Al-Kutub) ke IV tanggal 15 Maret 2011.

Sudjoko Prasodjo, dkk. 1982. Profil Pesantren; Laporan Hasil Penelitian Pesantren Al Falak dan Delapan Pesantren Lain di Bogor. Jakarta: LP3ES.

Sukamto. 199. Kepemimpinan Kiai dalam Pesantren. Jakarta: Pustaka LP3ES. 
Wahjoetomo. 1997. Perguruan Tinggi Pesantren;

Pendidikan Alternatif Masa Depan.Jakarta: Gema Insani Press.

Yunanto, S., \&Harun, B. (2005).Terminology, history and categorization. In S. Yunanto (Ed.), Islamic education in South and Southeast Asia: Diversity, problems and strategy (pp. 19-36). Jakarta, ID: The RIDEP Institute.

Zuhairini et al. (1992). SejarahPendidikan Islam. Jakarta, ID: BumiAksara and Departemen Agama. 


\section{LAMPIRAN: PMA NOMOR 13 TAHUN 2014}

\section{BERITA NEGARA REPUBLIK INDONESIA \\ NO.822, 2014 \\ KEMENAG. ISLAM. PENDIDIKAN. KEAGAMAAN. PERATURAN MENTERI AGAMA REPUBLIK INDONESIA \\ NOMOR 13 TAHUN 2014 \\ TENTANG \\ PENDIDIKAN KEAGAMAAN ISLAM \\ DENGAN RAHMAT TUHAN YANG MAHA ESA \\ MENTERI AGAMA REPUBLIK INDONESIA,}

Menimbang:a. bahwa dalam rangka pelaksanaan ketentuan Pasal 9 ayat (3), Pasal 13 ayat (5), dan Pasal 19 ayat (2) Peraturan Pemerintah Nomor 55 Tahun 2007 tentang Pendidikan Agama dan Pendidikan Keagamaan, perlu menetapkan Peraturan Menteri Agama tentang Pendidikan Keagamaan Islam;

b. bahwa berdasarkan pertimbangan sebagaimana dimaksud pada huruf a, perlu menetapkan Peraturan Menteri Agama tentang Pendidikan Keagamaan Islam;

Mengingat: 1. Undang-Undang Nomor 20 Tahun 2003 tentang Sistem Pendidikan Nasional (Lembaran Negara Republik Indonesia Tahun 2003 Nomor 78, Tambahan Lembaran Negara Republik Indonesia Nomor 4301); 
2. Undang-Undang Nomor 14 Tahun 2005 tentang Guru dan Dosen (Lembaran Negara Republik Indonesia Tahun 2005 Nomor 157, Tambahan Lembaran Negara Republik Indonesia Nomor 456);

3. Peraturan Pemerintah Nomor 19 Tahun 2005 tentang Standar Nasional Pendidikan (Lembaran Negara Republik Indonesia Tahun 2005 Nomor 41, Tambahan Lembaran www.peraturan.go.id 2014, No.822 2 Negara Republik Indonesia Nomor 4496) sebagaimana telah diubah dengan Peraturan Pemerintah Nomor 32 tahun 2013 tentang Perubahan Peraturan Pemerintah Nomor 19 Tahun 2005 (Lembaran Negara Republik Indonesia Nomor 71, Tambahan lembaran negara nomor 5410);

4. Peraturan Pemerintah Nomor 47 Tahun 2008 tentang Wajib Belajar Pendidikan Dasar (Lembaran Negara Republik Indonesia 2008 Nomor 90, Tambahan Lembaran Negara Republik Indonesia Nomor 4863);

5. Peraturan Pemerintah Nomor 55 Tahun 2007 tentang Pendidikan Agama dan Pendidikan Keagamaan (Lembaran Negara Republik Indonesia Tahun 2007 Nomor 124, Tambahan Lembaran Negara Republik Indonesia Nomor 4769); 
6. Peraturan Pemerintah Nomor 48 Tahun 2008 tentang Pendanaan Pendidikan (Lembaran Negara Republik Indonesia Tahun 2008 Nomor 91, Tambahan Lembaran Negara Republik Indonesia Nomor 4864);

7. Peraturan Pemerintah Nomor 74 Tahun 2008 tentang Guru (Lembaran Negara Republik Indonesia Tahun 2008 Nomor 194, Tambahan Lembaran Negara Republik Indonesia Nomor 4941);

8. Peraturan Pemerintah Nomor 17 Tahun 2010 tentang Pengelolaan dan Penyelenggaraan Pendidikan (Lembaran Negara Republik Indonesia Tahun 2010 Nomor 23, Tambahan Lembaran Negara Republik Indonesia Nomor 5150) sebagaimana telah diubah dengan Peraturan Pemerintah Nomor 66 Tahun 2010 tentang Perubahan Atas Peraturan Pemerintah Nomor 17 Tahun 2010 tentang Pengelolaan dan Penyelenggaraan Pendidikan (Lembaran Negara Republik Indonesia Tahun 2010 Nomor 112, Tambahan Lembaran Negara Republik Indonesia Nomor 5157); 
9. Peraturan Presiden Nomor 47 Tahun 2009 tentang Pembentukan dan Organisasi Kementerian Negara sebagaimana telah beberapa kali diubah terakhir dengan Peraturan Presiden Nomor 55 Tahun 2013 tentang Perubahan Keempat Atas Peraturan Presiden Nomor 47 Tahun 2009 tentang Pembentukan dan Organisasi Kementerian Negara; www. peraturan.go.id 2014, No.822 3

10. Peraturan Presiden Nomor 24 Tahun 2010 tentang Kedudukan, Tugas, dan Fungsi Kementerian Negara serta Susunan Organisasi, Tugas, dan Fungsi Eselon I Kementerian Negara sebagaimana telah beberapa kali diubah terakhir dengan Peraturan Presiden Nomor 56 Tahun 2013 tentang Perubahan Keempat Atas Peraturan Presiden Nomor 24 Tahun 2010 tentang Kedudukan, Tugas, dan Fungsi Kementerian Negara serta Susunan Organisasi, Tugas, dan Fungsi Eselon 1 Kementerian Negara;

11. Peraturan Menteri Agama Nomor 10 Tahun 2010 tentang Organisasi dan Tata Kerja Kementerian Agama (Berita Negara Republik Indonesia Tahun 2010 Nomor 592) sebagaimana telah dua kali diubah terakhir dengan Peraturan 
Menteri Agama Nomor 80 Tahun 2013 tentang Perubahan Kedua Atas Peraturan Menteri Agama Nomor 10 Tahun 2010 tentang Organisasi dan Tata Kerja Kementerian Agama (Berita Negara Republik Indonesia Tahun 2013 Nomor 1202);

12. Peraturan Menteri Agama Nomor 13 Tahun 2012 tentang Organisasi dan Tata Kerja Instansi Vertikal Kementerian Agama (Berita Negara Republik Indonesia Tahun 2012 Nomor 851);

\section{MEMUTUSKAN:}

\section{Menetapkan: PERATURAN MENTERI AGAMA TENTANG PENDIDIKAN KEAGAMAAN ISLAM.}

\section{BAB I \\ KETENTUAN UMUM}

Pasal 1

Dalam Peraturan Menteri ini yang dimaksud dengan:

1. Pendidikan keagamaan Islam adalah pendidikan yang mempersiapkan peserta didik untuk dapat menjalankan peranan yang menuntut penguasaan pengetahuan tentang ajaran agama Islam dan/atau menjadi ahli ilmu agama Islam dan mengamalkan ajaran agama Islam. 
2. Pondok pesantren yang selanjutnya disebut pesantren adalah lembaga pendidikan keagamaan Islam yang diselenggarakan oleh masyarakat yang menyelenggarakan satuan pendidikan pesantren dan/atau secara terpadu menyelenggarakan jenis pendidikan lainnya.

3. Kitab kuning adalah kitab keislaman berbahasa Arab yang menjadi rujukan tradisi keilmuan Islam di pesantren.

4. Dirasah islamiyah adalah kajian tentang ilmu agama Islam yang tersusun secara sistematik, terstruktur, dan terorganisasi (madrasy).

5. Pola pendidikan mu'allimin adalah sistem pendidikan pesantren yang bersifat integratif dengan memadukan ilmu agama Islam dan ilmu umum dan bersifat komprehensif dengan memadukan intra, ekstra, dan kokurikuler.

6. Pendidikan diniyah adalah pendidikan keagamaan Islam yang diselenggarakan pada semua jalur dan jenjang pendidikan.

7. Pendidikan diniyah formal adalah lembaga pendidikan keagamaan Islam yang diselenggarakan oleh dan berada di dalam pesantren secara terstruktur dan berjenjang pada jalur pendidikan formal.

8. Pendidikan diniyah nonformal adalah pendidikan keagamaan Islam yang diselenggarakan dalam bentuk Madrasah Diniyah Takmiliyah, Pendidikan AlQur'an, Majelis Taklim, atau bentuk lain yang sejenis baik di dalam maupun di luar pesantren pada jalur pendidikan nonformal. 
9. Pendidikan diniyah informal adalah pendidikan keagamaan Islam dalam bentuk program yang diselenggarakan di lingkungan keluarga pada jalur pendidikan informal.

10. Diniyah takmiliyah yang selanjutnya disebut Madrasah Diniyah Takmiliyah adalah lembaga pendidikan keagamaan Islam pada jalur pendidikan nonformal yang diselenggarakan secara terstruktur dan berjenjang sebagai pelengkap pelaksanaan pendidikan agama Islam pada jenjang pendidikan dasar, menengah, dan tinggi.

11. Pendidikan Al-Qur'an adalah lembaga pendidikan keagamaan Islam yang bertujuan untuk memberikan pengajaran bacaan, tulisan, hafalan, dan pemahaman Al-Qur'an.

12. Majelis Taklim adalah lembaga atau kelompok masyarakat yang menyelenggarakan pendidikan keagamaan Islam yang bertujuan untuk meningkatkan pemahaman dan pengamalan ajaran agama Islam di kalangan masyarakat dalam kehidupan sehari-hari.

13. Kurikulum adalah seperangkat rencana dan pengaturan mengenai tujuan, isi, bahan pelajaran, dan cara yang digunakan sebagai pedoman penyelenggaraan kegiatan pembelajaran untuk mencapai tujuan pendidikan tertentu.

14. Evaluasi pendidikan adalah kegiatan pengendalian, penjaminan, dan penetapan mutu pendidikan terhadap berbagai komponen pendidikan pada pendidikan diniyah dan pesantren sebagai bentuk pertanggungjawaban penyelenggaraan pendidikan. 
15. Akreditasi adalah kegiatan penilaian kelayakan program dan/atau satuan pendidikan berdasarkan kriteria yang telah ditetapkan.

16. Badan Standar Nasional Pendidikan yang selanjutnya disebut BSNP adalah badan mandiri dan independen yang bertugas mengembangkan, memantau, dan mengendalikan standar nasional pendidikan.

17. Menteri adalah Menteri Agama.

18. Direktur Jenderal adalah Direktur Jenderal Pendidikan Islam.

\section{Pasal 2}

Penyelenggaraan pendidikan keagamaan Islam bertujuan untuk:

a. menanamkan kepada peserta didik untuk memiliki keimanan dan ketaqwaan kepada Allah Subhanahu Wa Ta'ala;

b. mengembangkan kemampuan, pengetahuan, sikap dan keterampilan peserta didik untuk menjadi ahli ilmu agama Islam (mutafaqqih fiddin) dan/atau menjadi muslim yang dapat mengamalkan ajaran agama Islam dalam kehidupannya sehari-hari; dan

c. mengembangkan pribadi akhlakul karimah bagi peserta didik yang memiliki kesalehan individual dan sosial dengan menjunjung tinggi jiwa keikhlasan, kesederhanaan, kemandirian, persaudaran sesama umat Islam (ukhuwah Islamiyah), rendah hati (tawadhu), toleran (tasamuh), keseimbangan (tawazun), moderat (tawasuth), keteladanan (uswah), pola hidup sehat, dan cinta tanah air. 


\section{Pasal 3}

Pendidikan keagamaan Islam terdiri atas:

a. Pesantren; dan

b. Pendidikan diniyah.

\section{BAB II \\ PESANTREN \\ Bagian Kesatu \\ Umum \\ Pasal 4}

Pesantren wajib menjunjung tinggi dan mengembangkan nilai-nilai Islam rahmatan lil'alamin dengan menjunjung tinggi nilai-nilai Pancasila, Undang-Undang Dasar 1945, Negara Kesatuan Republik Indonesia, Bhineka Tunggal Ika, keadilan, toleransi, kemanusiaan, keikhlasan, kebersamaan, dan nilai-nilai luhur lainnya.

\section{Pasal 5}

Pesantren wajib memiliki unsur-unsur pesantren yang terdiri atas:

a. kyai atau sebutan lain yang sejenis;

b. santri;

c. pondok atau asrama pesantren;

d. masjid atau musholla, dan

e. pengajian dan kajian kitab kuning atau dirasah islamiyah dengan pola pendidikan mu'allimin.

Pasal 6

(1) Kyai atau sebutan lain yang sejenis sebagaimana dimaksud dalam Pasal 5 huruf a wajib berpendidikan pesantren dan memiliki kompetensi ilmu agama 
Islam yang bertugas membimbing, mengasuh, dan mengajar santri.

(2) Selain kyai sebagaimana dimaksud pada ayat (1), pesantren dapat memiliki pendidik lain yang diperlukan sesuai dengan keahlian yang dibutuhkan.

(3) Dalam rangka penyelenggaraan pendidikan, pesantren dapat memiliki tenaga kependidikan yang meliputi kepala satuan pendidikan, tenaga administrasi, pengelola perpustakaan, dan tenaga lain yang diperlukan.

\section{Pasal 7}

(1) Santri sebagaimana dimaksud dalam Pasal 5 huruf b adalah peserta didik dan wajib bermukim di pondok atau asrama pesantren.

(2) Kewajiban bermukim di pondok atau asrama pesantren sebagaimana dimaksud pada ayat (1) dimaksudkan untuk lebih mengintesifkan proses pendidikan baik yang menyangkut pengamalan ibadah, pemahaman keagamaan, penguasaan bahasa asing, internalisasi nilai-nilai keagamaan dan akhlak karimah, serta peningkatan keterampilan.

\section{Pasal 8}

(1) Pondok atau asrama pesantren sebagaimana dimaksud dalam Pasal 5 huruf c merupakan tempat tinggal santri selama masa proses pendidikan.

(2) Pondok atau asrama pesantren sebagaimana dimaksud pada ayat (1) wajib memenuhi persyaratan kenyamanan, keamanan, dan kesehatan. 


\section{Pasal 9}

(1) Masjid atau mushala sebagaimana dimaksud dalam Pasal 5 huruf $d 7$ berfungsi sebagai tempat ibadah dan/atau pembelajaran santri.

(2) Masjid atau mushala sebagaimana dimaksud pada ayat (1) bersifat terbuka bagi masyarakat di sekitar pesantren untuk melakukan ibadah dan/atau aktivitas keagamaan lainnya.

\section{Pasal 10}

(1) Pengajian dan kajian kitab kuning sebagaimana dimaksud dalam Pasal 5 huruf e dilakukan dengan menggunakan kitab kuning sebagai sumber belajar sesuai tingkatan peserta didik.

(2) Dirasah islamiyah dengan pola pendidikan mu'allimin sebagaimana dimaksud dalam Pasal 5 huruf e dilakukan dengan pendekatan tematik sesuai dengan kekhasan masing-masing pesantren.

\section{Pasal 11}

(1) Pesantren yang memiliki paling sedikit 15 (lima belas) santri wajib mendaftarkan ke Kantor Kementerian Agama Kabupaten/Kota.

(2) Pesantren yang telah terdaftar sebagaimana dimaksud pada ayat (1) diberikan tanda daftar pesantren oleh Kantor Kementerian Agama Kabupaten/ Kota.

(3) Ketentuan lebih lanjut mengenai pendaftaran pesantren sebagaimana dimaksud pada ayat (1) dan ayat (2) ditetapkan oleh Direktur Jenderal. 


\section{Bagian Kedua \\ Penyelenggaraan Pendidikan di Pesantren \\ Pasal 12}

Dalam penyelenggaraan pendidikan, pesantren dapat berbentuk sebagai satuan pendidikan dan/atau sebagai penyelenggara pendidikan.

\section{Paragraf 1 \\ Pesantren sebagai Satuan Pendidikan \\ Pasal 13}

(1) Pesantren sebagai satuan pendidikan sebagaimana dimaksud dalam Pasal 12 huruf a merupakan pesantren yang menyelenggarakan pengajian kitab kuning atau dirasah islamiyah dengan pola pendidikan mu'allimin.

(2) Penyelenggaraan pengajian kitab kuning sebagaimana dimaksud pada ayat (1) dapat dilakukan dalam bentuk pengajian kitab kuning pada umumnya dan/atau program takhasus pada bidang ilmu keislaman tertentu sesuai dengan ciri khas dan keunggulan masing-masing pesantren.

(3) Penyelenggaraan dirasah islamiyah dengan pola pendidikan mu'allimin sebagaimana dimaksud pada ayat (1) dilakukan secara integratif dengan memadukan ilmu agama Islam dan ilmu umum dan bersifat komprehensif dengan memadukan intra, ekstra, dan kokurikuler. 
(1) Muatan kurikulum pesantren sebagai satuan pendidikan meliputi AlQuran, Tafsir, Ilmu Tafsir, Hadits, Ulum Al-Hadits, Tauhid, Fiqh, Ushul Fiqh, Akhlak, Tasawuf, Tarikh, Bahasa Arab, Nahwu-Sharf, Balaghah, Ilmu Kalam, Ilmu 'Arudl, Ilmu Manthiq, Ilmu Falaq, dan disiplin ilmu lainnya.

(2) Selain muatan kurikulum sebagaimana dimaksud pada ayat (1), pesantren dapat menyelenggarakan program takhasus sebagaimana dimaksud dalam Pasal 13 ayat (2) yang meliputi tahfizh al-Qur'an, ilmu falaq, faraid, dan cabang dari ilmu keislaman lainnya.

\section{Pasal 15}

(1) Pembelajaran kitab kuning dapat dilakukan dengan menggunakan metode sorogan (individual), metode bandongan (massal), metode bahtsul masail, dan metode lainnya.

(2) Pembelajaran dirasah islamiyah dengan pola pendidikan mu'allimin dilakukan dengan metode kelasikal, terstruktur, dan berjenjang sesuai dengan struktur kurikulum yang ditetapkan oleh pesantren.

\section{Pasal 16}

Penjenjangan santri didasarkan atas penguasaan yang bersangkutan terhadap tingkatan kitab kuning atau dirasah islamiyah dengan pola pendidikan mu'allimin yang diajarkan.

\section{Pasal 17}

Kyai atau pendidik pada pesantren melakukan penilaian atas perkembangan, kemajuan dan hasil belajar santri. 


\section{Pasal 18}

(1) Hasil pendidikan pesantren sebagai satuan pendidikan dapat dihargai sederajat dengan pendidikan formal setelah lulus ujian yang diselenggarakan oleh satuan pendidikan yang terakreditasi dan ditunjuk oleh Direktur Jenderal.

(2) Ketentuan lebih lanjut mengenai hasil pendidikan pesantren sebagai satuan pendidikan sebagaimana dimaksud pada ayat (1) ditetapkan oleh Direktur Jenderal.

\section{Paragraf 2}

Pesantren sebagai Penyelenggara Pendidikan

\section{Pasal 19}

(1) Di samping sebagai satuan pendidikan, pesantren dapat menyelenggarakan satuan dan/atau program pendidikan lainnya.

(2) Satuan dan/atau program pendidikan lainnya sebagaimana dimaksud pada ayat (1) meliputi:

a. pendidikan diniyah formal;

b. pendidikan diniyah nonformal;

c. pendidikan umum;

d. pendidikan umum berciri khas Islam;

e. pendidikan kejuruan;

f. pendidikan kesetaraan;

g. pendidikan mu'adalah;

h. pendidikan tinggi; dan/atau

i. program pendidikan lainnya.

(3) Penyelenggaraan pendidikan mu'adalah sebagaimana dimaksud pada ayat (2) huruf g diatur dalam peraturan tersendiri. 
(4) Penyelenggaraan satuan dan/atau program pendidikan sebagaimana dimaksud pada ayat (2) dilakukan sesuai ketentuan peraturan perundangundangan.

\section{BAB III \\ PENDIDIKAN DINIYAH}

Bagian Kesatu

Umum

Pasal 20

Pendidikan diniyah terdiri atas:

a. Pendidikan diniyah formal;

b. Pendidikan diniyah nonformal; dan

c. Pendidikan diniyah informal.

Bagian Kedua

Pendidikan Diniyah Formal

Paragraf 1

Pendirian dan Penamaan

Pasal 21

(1) Pendirian satuan pendidikan diniyah formal wajib memperoleh izin dari Menteri.

(2) Satuan pendidikan diniyah formal didirikan dan dimiliki oleh pesantren.

(3) Peserta didik pendidikan diniyah formal wajib bermukim dalam lingkungan pesantren.

(4) Pendirian satuan pendidikan diniyah formal sebagaimana dimaksud pada ayat (1) wajib memenuhi persyaratan sebagai berikut: 
a. memenuhi persyaratan pesantren sebagai penyelenggara pendidikan;

b. memiliki kurikulum pendidikan diniyah formal;

c. memiliki jumlah dan kualifikasi pendidik dan tenaga kependidikan yang memadai;

d. memiliki sarana dan prasarana kegiatan pembelajaran yang berada di lingkungan pesantren;

e. memiliki sumber pembiayaan untuk kelangsungan pendidikan paling sedikit untuk 1 (satu) tahun pelajaran berikutnya;

f. memiliki sistem evaluasi pendidikan;

g. memiliki manajemen dan proses pendidikan yang akan diselenggarakan;

h. melampirkan pernyataan kesanggupan melaksanakan kurikulum yang ditetapkan pemerintah;

i. memiliki calon peserta didik paling sedikit 30 (tiga puluh) orang; dan

j. mendapatkan rekomendasi dari Kantor Wilayah Kementerian Agama provinsi setempat.

(5) Persyaratan pesantren sebagai penyelenggara pendidikan sebagaimana dimaksud pada ayat (4) huruf a meliputi:

a. memiliki tanda daftar pesantren dari Kantor Kementerian Agama kabupaten/kota;

b. organisasi nirlaba yang berbadan hukum;

c. memiliki struktur organisasi pengelola pesantren; dan

d. memiliki santri yang mukim dan belajar pada pesantren yang bersangkutan paling sedikit 300 (tiga ratus) orang pada setiap tahun selama 10 (sepuluh) tahun pelajaran terakhir. 
(6) Ketentuan lebih lanjut mengenai izin dan persyaratan pendirian pendidikan diniyah formal sebagaimana dimaksud pada ayat (1), ayat (2), ayat (4), dan ayat (5) ditetapkan oleh Direktur Jenderal.

\section{Pasal 22}

(1) Penamaan satuan pendidikan diniyah formal ditetapkan oleh penyelenggara satuan pendidikan yang bersangkutan.

(2) Penamaan satuan pendidikan diniyah formal sebagaimana dimaksud pada ayat (1) wajib mendapat persetujuan Kementerian Agama.

(3) Ketentuan lebih lanjut mengenai penamaan satuan pendidikan diniyah formal sebagaimana dimaksud pada ayat (1) dan ayat (2) ditetapkan oleh Direktur Jenderal.

\section{Paragraf 2 \\ Jenjang Pendidikan \\ Pasal 23}

(1) Pendidikan diniyah formal sebagaimana dimaksud dalam Pasal 20 huruf a terdiri atas:

a. Pendidikan diniyah formal jenjang pendidikan dasar;

b. Pendidikan diniyah formal jenjang pendidikan menengah; dan

c. Pendidikan diniyah formal jenjang pendidikan tinggi.

(2) Pendidikan diniyah formal jenjang pendidikan dasar sebagaimana dimaksud pada ayat (1) huruf a terdiri 
atas pendidikan diniyah formal ula dan pendidikan diniyah formal wustha.

(3) Pendidikan diniyah formal jenjang pendidikan menengah sebagaimana dimaksud pada ayat (1) huruf $\mathrm{b}$ berbentuk pendidikan diniyah formal ulya.

(4) Pendidikan diniyah formal jenjang pendidikan tinggi sebagaimana dimaksud pada ayat (1) huruf c berbentuk Ma'had Aly.

\section{Pasal 24}

(1) Pendidikan diniyah formal ula sebagaimana dimaksud dalam Pasal 23 ayat (2) merupakan pendidikan yang sederajat dan memiliki kewenangan yang sama dengan madrasah ibtidaiyah/sekolah dasar.

(2) Pendidikan diniyah formal wustha sebagaimana dimaksud dalam Pasal 23 ayat (2) merupakan pendidikan yang sederajat dan memiliki kewenangan yang sama dengan madrasah tsanawiyah/sekolah menengah pertama.

(3) Pendidikan diniyah formal ulya sebagaimana dimaksud dalam Pasal 23 ayat (3) merupakan pendidikan yang sederajat dan memiliki kewenangan yang sama dengan madrasah aliyah/sekolah menengah atas/sekolah menengah kejuruan.

(4) Pendidikan diniyah formal tingkat tinggi sebagaimana dimaksud dalam Pasal 23 ayat (4) diatur dalam peraturan tersendiri. 


\section{Pasal 25}

(1) Pendidikan diniyah formal ula sebagaimana dimaksud dalam Pasal 23 ayat (2) terdiri atas 6 (enam) tingkat.

(2) Pendidikan diniyah formal wustha sebagaimana dimaksud dalam Pasal 23 ayat (2) terdiri atas 3 (tiga) tingkat.

(3) Pendidikan diniyah formal ulya sebagaimana dimaksud dalam Pasal 23 ayat (3) terdiri atas 3 (tiga) tingkat.

\section{Paragraf 4 \\ Kurikulum \\ Pasal 26}

Kurikulum pendidikan diniyah formal terdiri atas kurikulum pendidikan keagamaan Islam dan kurikulum pendidikan umum.

\section{Pasal 27}

(1) Kurikulum pendidikan keagamaan Islam sebagaimana dimaksud dalam Pasal 26 pada satuan pendidikan diniyah formal ula paling sedikit memuat:

a. Al-Qur'an;

b. Hadits;

c. Tauhid;

d. Fiqh;

e. Akhlaq;

f. Tarikh; dan

g. Bahasa Arab.

(2) Kurikulum pendidikan keagamaan Islam sebagaimana dimaksud dalam Pasal 26 pada satuan pendidikan diniyah formal wustha paling sedikit memuat: 

a. Al-Qur'an;
b. Tafsir-Ilmu Tafsir;
c. Hadist-Ilmu Hadits;
d. Tauhid;
e. Fiqh-Ushul Fiqh;
f. Akhlaq-Tasawuf;
g. Tarikh;
h. Bahasa Arab;
i. Nahwu-Sharf;
j. Balaghah; dan
k. Ilmu Kalam.

(3) Kurikulum pendidikan keagamaan Islam sebagaimana dimaksud dalam Pasal 26 pada satuan pendidikan diniyah formal ulya paling sedikit memuat:
a. Al-Qur'an;
b. Tafsir-Ilmu Tafsir;
c. Hadist-Ilmu Hadits;
d. Tauhid;
e. Fiqh-Ushul Fiqh;
f. Akhlaq-Tasawuf;
g. Tarikh;
h. Bahasa Arab;
i. Nahwu-Sharf;
k. Balaghah;
l. Ilmu Kalam;
m. Ilmu Arudh;
n. Ilmu Mantiq; dan
o. Ilmu Falak. 
(1) Kurikulum pendidikan umum sebagaimana dimaksud dalam Pasal 26 pada satuan pendidikan diniyah formal ula dan pendidikan diniyah formal wustha paling sedikit memuat:

a. pendidikan kewarganegaraan;

b. bahasa Indonesia;

c. matematika; dan

d. ilmu pengetahuan alam.

(2) Kurikulum pendidikan umum sebagaimana dimaksud dalam Pasal 26 pada satuan pendidikan diniyah formal ulya paling sedikit memuat:

a. pendidikan kewarganegaraan;

c. bahasa Indonesia;

d. matematika;

e. ilmu pengetahuan alam; dan

f. seni dan budaya.

\section{Pasal 29}

Dalam rangka pelaksanaan kurikulum pendidikan keagamaan Islam sebagaimana dimaksud dalam Pasal 27 dan kurikulum pendidikan umum sebagaimana dimaksud dalam Pasal 28, Direktur Jenderal menetapkan kerangka dan struktur kurikulum.

\section{Paragraf 5 \\ Proses Pembelajaran \\ Pasal 30}

(1) Proses pembelajaran pada pendidikan diniyah formal dilaksanakan dengan memperhatikan aspek ketercapaian kompetensi, sumber dan sarana belajar, konteks/lingkungan, dan psikologi peserta didik. 
(2) Proses pembelajaran sebagaimana dimaksud pada ayat (1) dirumuskan dalam perencanaan pembelajaran dan penilaian.

\section{Paragraf 6 \\ Pendidik dan Tenaga Kependidikan \\ Pasal 31}

(1) Pendidik pada satuan pendidikan diniyah formal harus memenuhi kualifikasi dan persyaratan sebagai pendidik profesional sesuai dengan ketentuan peraturan perundang-undangan.

(2) Pendidik sebagaimana dimaksud pada ayat (1) mempunyai hak dan kewajiban sesuai dengan ketentuan peraturan perundang-undangan.

\section{Pasal 32}

(1) Tenaga kependidikan pada satuan pendidikan diniyah formal terdiri atas pengawas pendidikan Islam, kepala satuan pendidikan, wakil kepala satuan pendidikan, tenaga perpustakaan, tenaga administrasi, tenaga laboratorium, dan tenaga lain yang diperlukan untuk menunjang proses pembelajaran.

(2) Pengawas pendidikan Islam dan kepala satuan pendidikan sebagaimana dimaksud pada ayat (1) harus memenuhi kualifikasi dan persyaratan sesuai dengan ketentuan peraturan perundang-undangan.

(3) Ketentuan lebih lanjut mengenai tenaga kependidikan sebagaimana dimaksud pada ayat (1) dan ayat (2) ditetapkan oleh Direktur Jenderal. 


\section{Paragraf 7 \\ Peserta Didik \\ Pasal 33}

(1) Calon peserta didik satuan pendidikan diniyah formal tingkat ula minimal telah berusia 6 (enam) tahun.

(2) Calon peserta didik satuan pendidikan diniyah formal tingkat wustha harus memiliki ijazah pendidikan satuan pendidikan diniyah formal tingkat ula, MI, SD, SDLB, Paket A atau satuan pendidikan sederajat.

(3) Calon peserta didik satuan pendidikan diniyah formal tingkat ulya harus memiliki ijazah pendidikan satuan pendidikan diniyah formal tingkat wustha, MTs, SMP, SMPLB, Paket $B$ atau satuan pendidikan sederajat.

(4) Satuan pendidikan diniyah formal tingkat wushta dan ulya dapat melakukan penetapan persyaratan kompetensi minimal calon peserta didik.

(5) Ketentuan lebih lanjut mengenai persyaratan kompetensi minimal calon peserta didik sebagaimana dimaksud pada ayat (4) ditetapkan oleh Direktur Jenderal.

\section{Pasal 34}

Peserta didik yang dinyatakan lulus pada satuan pendidikan diniyah formal berhak melanjutkan ke jenjang dan tingkat pendidikan yang lebih tinggi baik yang sejenis maupun tidak sejenis sesuai dengan ketentuan peraturan perundang-undangan. 


\section{Paragraf 8 \\ Sarana dan Prasarana \\ Pasal 35}

(1) Satuan pendidikan diniyah formal harus memenuhi persyaratan standar sarana pendidikan sesuai ketentuan peraturan perundangundangan.

(2) Selain persyaratan standar sarana pendidikan sebagaimana dimaksud pada ayat (1), satuan pendidikan diniyah formal wajib memiliki masjid dan kitab keislaman sebagai sumber belajar.

Pasal 36

Satuan pendidikan diniyah formal wajib memiliki prasarana pendidikan paling sedikit meliputi lahan, ruang kelas, ruang pimpinan satuan pendidikan, ruang pendidik, ruang tata usaha, ruang perpustakaan, ruang laboratorium, dan prasarana lainnya yang diperlukan dalam rangka proses pembelajaran.

\section{Paragraf 9}

Pengelolaan Pendidikan

Pasal 37

(1) Pengelolaan satuan pendidikan diniyah formal dilakukan dengan menerapkan manajemen dengan prinsip keadilan, kemandirian, kemitraan dan partisipasi, nirlaba, efisiensi, efektivitas, dan akuntabilitas.

(2) Pengelolaan secara umum satuan pendidikan diniyah formal menjadi tanggung jawab pesantren.

(3) Pengelolaan secara teknis satuan pendidikan diniyah formal menjadi tanggung jawab kepala satuan pendidikan diniyah formal.

158 | Pendidikan Diniyah Formal 


\section{Pasal 38}

Pembinaan pengelolaan satuan pendidikan diniyah formal dilakukan oleh Menteri.

\section{Pasal 39}

(1) Setiap satuan pendidikan diniyah formal dikelola atas dasar rencana kerja tahunan yang merupakan penjabaran rinci dari rencana kerja jangka menengah satuan pendidikan diniyah formal untuk masa 4 (empat) tahun.

(2) Rencana kerja tahunan sebagaimana dimaksud pada ayat (1) meliputi:

a. kalender pendidikan yang meliputi jadual pembelajaran, ulangan, ujian, kegiatan ekstra kurikuler, dan hari libur;

b. jadual pelajaran per semester;

c. penugasan pendidik pada mata pelajaran dan kegiatan lainnya;

d. jadual penyusunan kurikulum tingkat satuan pendidikan diniyah formal;

e. pemilihan dan penetapan kitab dan buku teks pelajaran yang digunakan untuk setiap mata pelajaran;

f. jadual penggunaan dan pemeliharaan sarana dan prasarana pembelajaran;

g. pengadaan, penggunaan, dan persediaan minimal barang habis pakai;

h. program peningkatan mutu pendidikan dan tenaga kependidikan yang meliputi paling sedikit jenis, durasi, peserta, dan penyelenggara program; 
i. jadual rapat dewan pendidik, rapat konsultasi satuan pendidikan diniyah formal dengan orang tua/wali peserta didik, dan rapat satuan pendidikan diniyah formal dengan komite satuan pendidikan diniyah formal;

j. rencana anggaran pendapatan dan belanja satuan pendidikan diniyah formal untuk masa kerja 1 (satu) tahun; dan

k. jadual penyusunan laporan keuangan dan laporan kinerja satuan pendidikan diniyah formal untuk 1 (satu) tahun terakhir.

(3) Rencana kerja satuan pendidikan diniyah formal sebagaimana dimaksud pada ayat (1) dan ayat (2) harus disetujui oleh rapat dewan pendidik.

(4) Komite satuan pendidikan diniyah formal dapat memberikan masukan dan pertimbangan dalam penyusunan rencana kerja satuan pendidikan diniyah formal sebagaimana dimaksud pada ayat (1) dan ayat (2).

\section{Pasal 40}

(1) Setiap satuan pendidikan diniyah formal wajib memiliki pedoman yang mengatur tentang:
a. struktur organisasi;
b. pembagian tugas pendidik;
c. pembagian tugas tenaga kependidikan;
d. kurikulum tingkat satuan pendidikan dan silabus;


e. kalender pendidikan yang berisi seluruh program dan kegiatan satuan pendidikan diniyah formal selama 1 (satu) tahun pelajaran yang dirinci secara semesteran, bulanan, dan mingguan;

f. peraturan akademik;

g. tata tertib pendidik, tenaga kependidikan, dan peserta didik;

h. peraturan penggunaan dan pemeliharaan sarana dan prasarana;

i. kode etik hubungan antara sesama warga satuan pendidikan diniyah formal dan hubungan antara warga satuan pendidikan diniyah formal dan masyarakat; dan

j. biaya operasional.

(2) Ketentuan mengenai pedoman pengelolaan satuan pendidikan diniyah formal sebagaimana dimaksud pada ayat (1) ditetapkan oleh Direktur Jenderal.

Paragraf 10

Penilaian dan Kelulusan

Pasal 41

(1) Penilaian pendidikan pada satuan pendidikan diniyah formal dilakukan oleh pendidik, satuan pendidikan diniyah formal, dan Pemerintah.

(2) Penilaian oleh pendidik sebagaimana dimaksud pada ayat (1) dilakukan secara berkesinambungan yang bertujuan untuk memantau proses dan kemajuan belajar peserta didik. 
(3) Penilaian oleh satuan pendidikan diniyah formal sebagaimana dimaksud pada ayat (1) dilakukan untuk menilai pencapaian kompetensi peserta didik pada semua mata pelajaran.

(4) Penilaian oleh Pemerintah sebagaimana dimaksud pada ayat (1) dilakukan dalam bentuk ujian akhir pendidikan diniyah formal berstandar nasional.

(5) Ketentuan lebih lanjut mengenai ujian akhir pendidikan diniyah formal berstandar nasional ditetapkan oleh Direktur Jenderal.

\section{Pasal 42}

Penilaian sebagaimana dimaksud dalam Pasal 41 dilakukan sesuai dengan ketentuan peraturan perundangundangan.

\section{Pasal 43}

(1) Peserta didik yang telah menyelesaikan proses pendidikan dan dinyatakan lulus ujian satuan pendidikan serta ujian akhir pendidikan diniyah formal berstandar nasional diberikan ijazah sesuai dengan ketentuan peraturan perundang-undangan.

(2) Ketentuan lebih lanjut mengenai ijazah sebagaimana dimaksud pada ayat (1) ditetapkan oleh Direktur Jenderal.

\section{Paragraf 11 \\ Akreditasi \\ Pasal 44}

(1) Penyelenggaraan satuan pendidikan diniyah formal wajib mengikuti proses akreditasi. 
(2) Akreditasi sebagaimana dimaksud pada ayat (1) dilakukan oleh badan akreditasi sesuai dengan ketentuan peraturan perundang-undangan.

Bagian Ketiga

Pendidikan Diniyah Nonformal

Pasal 45

(1) Pendidikan diniyah nonformal diselenggarakan dalam bentuk:

a. madrasah diniyah takmiliyah;

b. pendidikan Al-Qur'an;

c. majelis taklim; atau d. pendidikan keagamaan Islam lainnya.

(2) Pendidikan diniyah nonformal sebagaimana dimaksud pada ayat (1) dapat diselenggarakan dalam bentuk satuan pendidikan atau program.

(3) Pendidikan diniyah nonformal yang diselenggarakan dalam bentuk satuan pendidikan sebagaimana dimaksud pada ayat (2) wajib mendapatkan izin dari Kantor Kementerian Agama kabupaten/kota.

(4) Pendidikan diniyah nonformal yang diselenggarakan dalam bentuk program sebagaimana dimaksud pada ayat (2) dan memiliki peserta didik paling sedikit 15 (lima belas) orang harus mendaftarkan ke Kantor Kementerian Agama kabupaten/kota.

(5) Pendidikan diniyah nonformal yang telah terdaftar sebagaimana dimaksud pada ayat (3) dan ayat (4) diberikan tanda daftar oleh Kementerian Agama. 
(6) Pendidikan diniyah nonformal yang telah terdaftar sebagaimana dimaksud pada ayat (5) berhak mendapatkan pembinaan dari Kementerian Agama dan pemerintah daerah.

(7) Ketentuan lebih lanjut mengenai pendaftaran pendidikan diniyah nonformal sebagaimana dimaksud pada ayat (5) ditetapkan oleh Direktur Jenderal.

\section{Paragraf 1 \\ Madrasah Diniyah Takmiliyah \\ Pasal 46}

(1) Madrasah diniyah takmiliyah sebagaimana dimaksud dalam Pasal 45 ayat (1) huruf a diselenggarakan untuk melengkapi, memperkaya, dan memperdalam pendidikan agama Islam pada MI/SD, MTs/SMP, MA/SMA/MAK/SMK, dan pendidikan tinggi atau yang sederajat dalam rangka peningkatan keimanan dan ketakwaan peserta didik kepada Allah SWT.

(2) Madrasah diniyah takmiliyah sebagaimana dimaksud pada ayat (1) dilselenggarakan secara berjenjang.

(3) Jenjang sebagaimana dimaksud pada ayat (1) terdiri atas jenjang ula, wustha, ulya, dan al-jami'ah.

(4) Jenjang ula sebagaimana dimaksud pada ayat (3) diikuti oleh peserta didik pada MI/SD atau yang sederajat.

(5) Jenjang wustha sebagaimana dimaksud pada ayat (3) diikuti oleh peserta didik pada MTs/SMP atau yang sederajat. 
(6) Jenjang ulya sebagaimana dimaksud pada ayat (3) diikuti oleh peserta didik pada MA/SMA/MAK/SMK atau yang sederajat.

(7) Jenjang al-jami'ah sebagaimana dimaksud pada ayat (3) diikuti oleh peserta didik pada pendidikan tinggi.

Pasal 47

(1) Madrasah diniyah takmiliyah sebagaimana dimaksud dalam Pasal 45 ayat (1) huruf a diselenggarakan oleh masyarakat.

(2) Madrasah diniyah takmiliyah sebagaimana dimaksud pada ayat (1) dapat diselenggarakan secara mandiri atau terpadu dengan satuan pendidikan lainnya.

(3) Madrasah diniyah takmiliyah sebagaimana dimaksud pada ayat (1) dapat diselenggarakan oleh pesantren, pengurus masjid, pengelola pendidikan formal dan nonformal, organisasi kemasyarakatan Islam, dan lembaga sosial keagamaan Islam lainnya.

(4) Madrasah diniyah takmiliyah sebagaimana dimaksud pada ayat (1) dapat diselenggarakan di masjid, mushalla, ruang kelas, atau ruang belajar lain yang memenuhi syarat.

(5) Pesantren yang menyelenggarakan madrasah diniyah takmiliyah dapat mengembangkan kekhasan masingmasing pesantren.

(6) Ketentuan lebih lanjut mengenai penyelenggaraan madrasah diniyah takmiliyah sebagaimana dimaksud pada ayat (1), ayat (2), ayat (3), dan ayat (4) ditetapkan oleh Direktur Jenderal. 


\section{Pasal 48}

(1) Kurikulum madrasah diniyah takmiliyah terdiri atas mata pelajaran pendidikan keagamaan Islam yang paling sedikit meliputi:
a. Al-Qur'an; b. Al-Hadits;
b. Fiqih;
c. Akhlak;
d. Sejarah Kebudayaan Islam; dan
e. Bahasa Arab.

(2) Ketentuan lebih lanjut mengenai kurikulum sebagaimana dimaksud pada ayat (1) ditetapkan oleh Direktur Jenderal.

\section{Pasal 49}

(1) Lulusan madrasah diniyah takmiliyah dapat dihargai sederajat dengan pendidikan formal setelah lulus ujian yang diselenggarakan oleh satuan pendidikan yang terakreditasi dan ditunjuk oleh Direktur Jenderal.

(2) Lulusan madrasah diniyah takmiliyah yang memperoleh ijazah sederajat pendidikan formal sebagaimana dimaksud pada ayat (1) dapat melanjutkan ke jenjang berikutnya pada jenis pendidikan lainnya.

(3) Ketentuan lebih lanjut mengenai lulusan madrasah diniyah takmiliyah sebagaimana dimaksud pada ayat (1) dan ayat (2) ditetapkan oleh Direktur Jenderal. 


\section{Paragraf 2 \\ Pendidikan Al-Qur'an \\ Pasal 50}

(1) Pendidikan Al-Qur'an sebagaimana dimaksud dalam Pasal 45 ayat (1) huruf b diselenggarakan oleh masyarakat.

(2) Pendidikan Al-Qur'an sebagaimana dimaksud pada ayat (1) dapat diselenggarakan oleh pesantren, pengurus masjid, organisasi kemasyarakatan Islam, dan lembaga sosial keagamaan Islam lainnya.

(3) Pendidikan Al-Qur'an sebagaimana dimaksud pada ayat (1) dapat diselenggarakan di masjid, mushalla, ruang kelas, atau ruang belajar lain yang memenuhi syarat.

(4) Kurikulum pendidikan Al-Qur'an adalah membaca, menulis dan menghafal ayat-ayat Al-Qur'an, tajwid, serta menghafal doa-doa utama.

(5) Pendidik pada pendidikan Al-Qur'an harus memiliki kompetensi membaca Al-Qur'an dengan tartil dan menguasai teknik pengajaran AlQur'an.

(6) Ketentuan lebih lanjut mengenai penyelenggaraan Pendidikan AlQur'an sebagaimana dimaksud pada ayat (1), ayat (2), ayat (3), ayat (4), dan ayat (5) ditetapkan oleh Direktur Jenderal.

Paragraf 3

Majelis Taklim

Pasal 51

(1) Majelis taklim sebagaimana dimaksud dalam Pasal 45 ayat (1) huruf c dapat diselenggarakan oleh masyarakat. 
(2) Majelis taklim sebagaimana dimaksud pada ayat (1) dapat diselenggarakan oleh pesantren, pengurus masjid, organisasi kemasyarakatan Islam, dan lembaga sosial keagamaan Islam lainnya.

(3) Majelis taklim sebagaimana dimaksud pada ayat (1) dapat diselenggarakan di masjid, mushalla, ruang kelas, atau ruang belajar lain yang memenuhi syarat.

(4) Majelis taklim dapat mengembangkan kajian keislaman secara tematis dan terprogram dalam rangka peningkatan pemahaman dan pengamalan ajaran agama Islam.

(5) Ketentuan lebih lanjut mengenai penyelenggaraan majelis taklim sebagaimana dimaksud pada ayat (1), ayat (2), ayat (3), dan ayat (4) ditetapkan oleh Direktur Jenderal. Bagian Keempat Pendidikan Diniyah Informal

Pasal 52

(1) Pendidikan diniyah informal sebagaimana dimaksud dalam Pasal 20 huruf c diselenggrakan oleh masyarakat dalam rangka meningkatkan pemahaman dan pengamalan ajaran agama Islam.

(2) Pendidikan diniyah informal sebagaimana dimaksud pada ayat (1) diselenggarakan dalam bentuk kegiatan pendidikan keagamaan Islam di lingkungan keluarga. 


\section{BAB IV \\ PEMBIAYAAN}

Pasal 53

(1) Pembiayaan pendidikan keagamaan Islam bersumber dari:
a. penyelenggara;
b. pemerintah;
c. pemerintah daerah;
d. masyarakat; dan/atau
e. sumber lain yang sah.

(2) Pembiayaan pendidikan keagamaan Islam sebagaimana dimaksud pada ayat (1) dikelola secara efektif, efisien, transparan, dan akuntabel.

\section{BAB V \\ PEMBINAAN DAN PENGAWASAN \\ Pasal 54}

(1) Pembinaan dan pengawasan terhadap pendidikan keagamaan Islam dilakukan untuk menjamin mutu dan akuntabilitas penyelenggaraan pendidikan.

(2) Pembinaan dan pengawasan sebagaimana dimaksud pada ayat (1) dilakukan oleh pengawas pendidikan Islam di lingkungan Kementerian Agama.

(3) Pembinaan dan pengawasan sebagaimana dimaksud pada ayat (1) dan ayat (2) dilakukan sesuai ketentuan peraturan perundang-undangan. 


\title{
BAB VI \\ KETENTUAN PENUTUP
}

\section{Pasal 55}

Pada saat Peraturan Menteri ini mulai berlaku maka semua peraturan perundang-undangan yang mengatur mengenai pendidikan keagamaan Islam dinyatakan tetap berlaku sepanjang tidak bertentangan atau belum diganti dengan yang baru berdasarkan Peraturan Menteri Agama ini.

\section{Pasal 56}

Peraturan Menteri ini mulai berlaku pada tanggal diundangkan. Agar setiap orang mengetahuinya, memerintahkan pengundangan Peraturan Menteri ini dengan penempatannya dalam Berita Negara Republik Indonesia.

\author{
Ditetapkan di Jakarta \\ pada tanggal 18 Juni 2014 \\ MENTERI AGAMA \\ REPUBLIK INDONESIA,
}

SURYADHARMA ALI

\begin{abstract}
Diundangkan di Jakarta
pada tanggal 18 Juni 2014

MENTERI HUKUM DAN HAK ASASI MANUSIA

REPUBLIK INDONESIA,
\end{abstract}

AMIR SYAMSUDIN

170 | Pendidikan Diniyah Formal 


\section{TENTANG PENULIS}

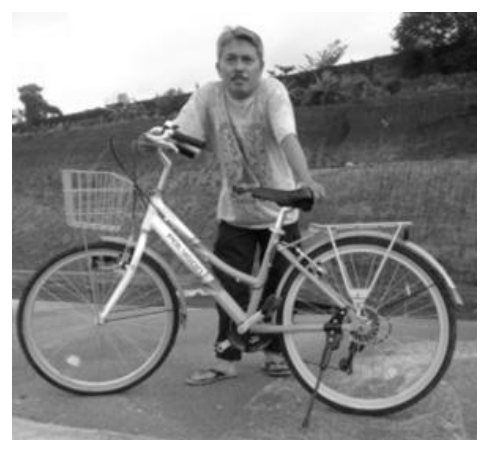

Mulyani Mudis Taruna, lahir di Brebes tanggal 31 Januari 1967, meraih gelar sarjana S.1 dari Fakultas Tarbiyah IAIN Walisongo Semarang lulus tahun 1992 dan S.2 dari Universitas Negeri Yogyakarta Program Penelitian dan Evaluasi Pendidikan (PEP) lulus tahun 2001. Pernah mengikuti Program Peningkatan Kemampuan Peneliti Agama (PKPA) di Jakarta dan Peningkatan dan Diklat Fungsional Peneliti tingkat Lanjutan di Pusbindiklat LIPI Cibinong tahun 2013. Sampai sekarang masih aktif melakukan kegiatan penelitian bidang Pendidikan Agama dan Keagamaan pada Balai Penelitian dan Pengembangan Agama Semarang (BLAS). Diantara penelitian yang telah diselesaikan tahun 2017/2018 antara lain Pendidikan Agama dalam Konstelasi Globalpada Daerah Terpencil di Jawa Tengah, Implementasi Full Day School (FDS) terhadap Pondok Pesantren Al Akhlakul Karimah Budi Mulyo 
Yogyakarta, Perspektif Siswa Dalam Bingkai Kebangsaan (Studi Kasus Pada Organisasi Rohis Sman 1 Sleman Yogyakarta), dan Pendidikan Kesehatan Reproduksi RemajaKajian Kritis dalam Perspektif Kurikulum. Penulis juga aktif menulis dalam bentuk Prosiding, Bungarampai, dan beberapa jurnal terakreditas. 


\section{PENDIDIKAN DINIYAH FORMAL}

Pusat Kaderisasi Ulama Toleran

Seiring dengan perkembangan zaman dan tuntutan masyarakat secara umum, pondok pesantren mulai membuka dan menyelenggarakan lembaga pendidikan formal yang dapat melanjutkan studi ke jenjang yang lebih tinggi diluar pondok pesantren.

Membaca buku ini paling tidak memunculkan empat pertanyaan mendasar, yaitu pertama,mungkinkah pendidikan diniyah menjadi- lembaga pendidikan formal sebagaimana sekolah formal pada umumnya? Hal ini karena pendidikan diniyah dalam sejarahnya adalah lembaga pendidikan non formal. Kedua, Kalau ada ulama toleran maka secara implisit terdapat ulama yang intoleran, bagaiman dengan ulama yang didik pada Pendidikan Diniyah Formal (PDF) Ulya Al Fithrah?, dan yang ketiga benarkah pendidikan diniyah yang diformalkan dapat dijadikan pusat kaderisasi ulama?, lalu bagaimana dengan pondok pesantren salafiyah yang selama ini memproduk ulama-ulama penerus ulama salafussholih sebagai pertanyaan yang keempat. Dari keempat pertanyaan tersebut dijawab dalam buku ini melalui kajian riset yang mendalam.

Semoga Buku ini bisa memberikan banyak manfaat bagi pembaca sekalian. Amin

ISBN 978-602-6244-43-?
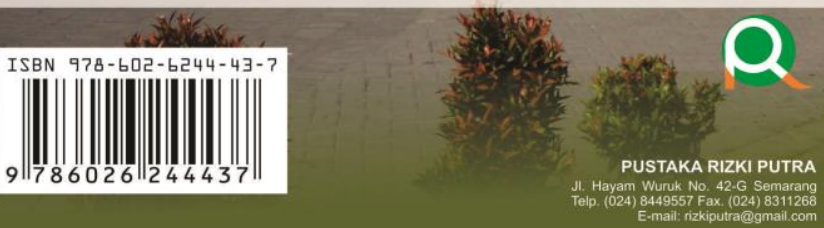